\title{
Low-Cost Options for Moderate Levels of Mercury Control
}

\author{
Topical Report for \\ MidAmerican's Louisa Generating Station \\ Reporting Period: January 1-March 31, 2006 \\ Principal Author: Sharon Sjostrom \\ Submitted: December 2006
}

DOE Award Number DE-FC26-05NT42307

Report Number 42307R08

ADA-ES, Inc.

8100 SouthPark Way, Unit B

Littleton, Colorado 80120

(303) 797-8729 


\section{DISCLAIMER}

This technical report was prepared with the support of the U.S. Department of Energy, under Award No. DE-FC26-05NT42307. However, any opinions, findings, conclusions, or recommendations expressed herein are those of the author(s) and do not necessarily reflect the views of the DOE.

This report was prepared as an account of work sponsored by an agency of the United States Government. Neither the United States Government nor any agency thereof, nor any of their employees, makes any warranty, express or implied, or assumes any legal liability or responsibility for the accuracy, completeness, or usefulness of any information, apparatus, product, or process disclosed, or represents that its use would not infringe privately owned rights. Reference herein to any specific commercial product, process, or service by trade name, trademark, manufacturer, or otherwise does not necessarily constitute or imply its endorsement, recommendation, or favoring by the United States Government or any agency thereof. The views and opinions of authors expressed herein do not necessarily state or reflect those of the United States Government or any agency thereof. 


\section{ABSTRACT}

On March 15, 2005, EPA issued the Clean Air Mercury Rule, requiring phased-in reductions of mercury emissions from electric power generators. ADA-ES, Inc., with support from DOE/NETL and industry partners, is conducting evaluations of EPRI's TOXECON II ${ }^{\mathrm{TM}}$ process and of high-temperature reagents and sorbents to determine the capabilities of sorbent/reagent injection, including activated carbon, for mercury control on different coals and air emissions control equipment configurations.

DOE/NETL targets for total mercury removal are $\geq 55 \%$ (lignite), $\geq 65 \%$ (subbituminous), and $\geq 80 \%$ (bituminous). Based on work done to date at various scales, meeting the removal targets appears feasible. However, work needs to progress to more thoroughly document and test these promising technologies at full scale.

This is the final site report for tests conducted at MidAmerican's Louisa Station, one of three sites evaluated in this DOE/NETL program. The other two sites in the program are MidAmerican’s Council Bluff Station and Entergy’s Independence Station.

MidAmerican's Louisa Station burns Powder River Basin (PRB) coal and employs hot-side electrostatic precipitators with flue gas conditioning for particulate control. This part of the testing program evaluated the effect of reagents used in the existing flue gas conditioning on mercury removal. 


\section{TABLE OF CONTENTS}

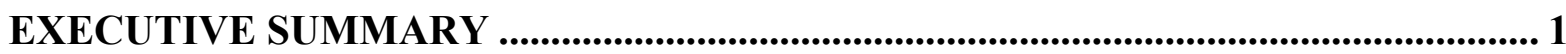

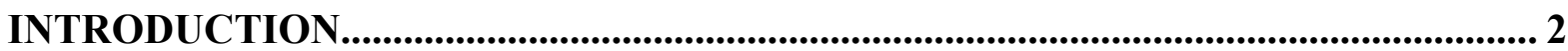

Description of Overall Program .......................................................................... 2

Site Testing Overview...................................................................................................................... 4

PROJECT OBJECTIVES AND TECHNICAL APPROACH........................................... 5

Importance of Testing at Louisa............................................................................................. 5

LOUISA GENERATING STATION SITE DESCRIPTION ........................................... 6

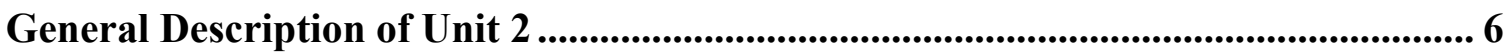

Description of Sorbent Injection and Mercury Monitoring Locations.................... 8

EQUIPMENT DESCRIPTIONS............................................................................................... 10

ADA-37 Injection System .................................................................................................... 10

ALSTOM KNX Injection System..................................................................................... 11

Mercury Monitoring System.................................................................................................... 11

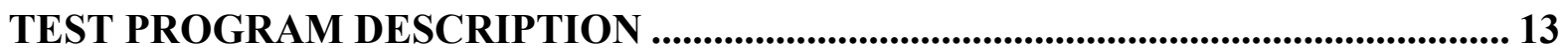

Description of Field-Testing Tasks.............................................................................. 13

Sample and Data Collection Coordination ................................................................. 13

Overview of Test Program Sequence ..................................................................................... 14

Baseline and Parametric Testing (No Sorbent Injection) ................................................. 14

Parametric Testing................................................................................................................. 14

RESULTS FROM LOUISA TESTING ................................................................................ 15

Mercury Removal Results ................................................................................................ 15

ADA-37 Tests....................................................................................................................... 15

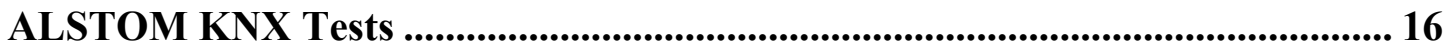

Coal and Ash Analyses ................................................................................................. 17

ESP Performance ...................................................................................................................... 18

Results of EPA M26A Testing .......................................................................................... 19

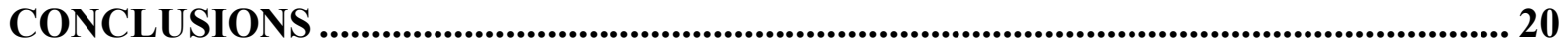

APPENDIX A: Louisa Test Plan ................................................................................................ 21

APPENDIX B: Sample Collection and Management Plan ..................................................... 44

APPENDIX C: Gaseous Emissions Test, GE Energy ..............................................................56

Louisa Topical Report $\quad$ iii 


\section{LIST OF TABLES}

Table 1. Host Site Key Descriptive Information. ....................................................3

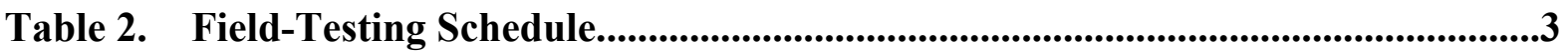

Table 3. Louisa Key Operating Parameters................................................................6

Table 4. Data Collected during Field Testing. ...............................................................13

Table 5. Louisa Unit 2 Coal Analysis, Dry Basis. ...............................................................17

Table 6. Mineral Analysis of Ashed Coal, 2/9/06 Sample. ...........................................17

\section{LIST OF FIGURES}

Figure 1. Sketch of Louisa Unit 2 General Configuration...............................................7

Figure 2. Single ESP Box Electrical Field Configuration. .................................................7

Figure 3. Louisa Boiler Arrangement Indicating Burners with KNX-Treated

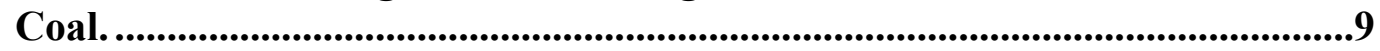

Figure 4. ADA-37 Injection Skid Installed at Louisa Generating Station.....................10

Figure 5. Sketch of SCEM Mercury Measurement System..........................................12

Figure 6. Mercury Removal Trends during Baseline and ADA-37 Testing..................15

Figure 7. Mercury Speciation and KNX Injection Rate................................................16

Figure 8. Opacity Trends during Parametric Testing.................................................18

Figure 9. Results from EPA M26A Measurements at Louisa.....................................19 


\section{EXECUTIVE SUMMARY}

Power plants that burn Powder River Basin (PRB) coal and have only hot-side electrostatic precipitators (ESPs) for air pollution control represent a challenging configuration for controlling mercury emissions. Limited testing on hot-side ESP configurations with injecting conventional powdered activated carbons just upstream of the ESP has indicated these sorbents perform very poorly at the elevated temperatures associated with hot-side ESP installations.

In order to further the understanding of potential mercury control systems for power plants burning PRB coals and using hot-side ESPs for air pollution control, DOE selected ADA-ES, Inc., to conduct a test program at MidAmerican's Louisa Generating Station to evaluate the mercury removal effectiveness of the hot-side flue gas conditioning agent, ADA-37, currently in use at Louisa and any synergistic effects of ALSTOM's coal additive, KNX. Testing was conducted from January 28 to February 13, 2006. The plant burned the normal subbituminous PRB fuel during the test program. This report provides the results from the test program.

The effect of both ADA-37 and KNX was tested during the parametric test period. Although ADA-37 is typically on at Louisa, data were collected without ADA-37 and at three different injection rates $(6,12$, and 18 gallons per hour). KNX was injected at two different rates ( 3 and 8 gallons per hour). Results indicate that ADA-37 is not effective at removing mercury across a hot-side ESP. KNX appeared to increase the fraction of oxidized mercury, but no net increase in mercury removal was noted with KNX. 


\section{INTRODUCTION}

\section{Description of Overall Program}

The test program at MidAmerican's Louisa Generating Station is part of a three-site program funded by the Department of Energy's National Energy Technology Laboratory (DOE/NETL) and industry partners to obtain the necessary information to assess the feasibility and costs of controlling mercury from coal-fired utility plants using either hightemperature sorbents or EPRI's TOXECON II ${ }^{\mathrm{TM}}$ process. High-temperature sorbents are included in the test programs at MidAmerican's Louisa Station and Council Bluffs Station. Sorbent injection into an electrostatic precipitator (ESP), or TOXECON IITM, is the focus of testing at Entergy's Independence Station. All of these sites fire Powder River Basin (PRB) coal and currently achieve less than $20 \%$ mercury removal. Key descriptive information about these plants is included in Table 1. Table 2 shows the test schedule for the overall program.

The technical approach followed during this program allowed the team to evaluate the potential of ADA-37 and ALSTOM's coal additive KNX. These technical objectives were accomplished by following a series of tasks, as listed below. These tasks are repeated for each test site.

Task 1. Site Coordination, Kickoff Meeting, Test Plan and QA/QC Plan

Task 2. Design and Install Site-Specific Equipment

Task 3. Sorbent Selection

Task 4. Field-Tests - Baseline Tests

Task 5. Field-Tests - Parametric Tests

Task 6. Field-Tests - Long-Term Tests (not included at Louisa)

Task 7. Data Analysis

Task 8. Sample Evaluation

Task 9. Site Report

Task 10. Technology Transfer

Task 11. Management and Reporting

A detailed description of each task is given in the Test Plan for Louisa included in Appendix A. 
Table 1. Host Site Key Descriptive Information.

\begin{tabular}{|l|c|c|c|}
\hline & $\begin{array}{c}\text { Entergy } \\
\text { Independence }\end{array}$ & $\begin{array}{c}\text { MidAmerican } \\
\text { Council Bluffs }\end{array}$ & $\begin{array}{c}\text { MidAmerican } \\
\text { Louisa }\end{array}$ \\
\hline & TOXECON IITM & \multicolumn{2}{|c|}{ High-Temperature Sorbents } \\
\hline Unit No. & 1 & 2 & 1 \\
\hline Size (MW) & 842 & 88 & 700 \\
\hline Test Portion (MW) & 210 & 88 & 700 \\
\hline Coal & PRB & PRB & PRB \\
\hline \multicolumn{1}{|c|}{ Heating Value (as rec'd.) } & 8,870 & 8,425 & 8,500 \\
\hline \multicolumn{1}{|c|}{ Sulfur (\% by weight) } & 0.32 & 0.32 & 0.32 \\
\hline \multicolumn{1}{|c|}{ Chlorine (ppm) } & 50 & $50-100$ & $50-100$ \\
\hline \multicolumn{1}{|c|}{ Mercury ( $\mu$ g/g) } & 0.04 & 0.08 & 0.08 \\
\hline Particulate Control & Cold-Side ESP & Hot-Side ESP & Hot-Side ESP \\
\hline SCA/fields (ft ${ }^{2} /$ kacfm) & $542 / 8$ & $224 / 4$ & $459 / 5$ \\
\hline Sulfur Control & Compliance Coal & Compliance Coal & Compliance Coal \\
\hline Disposition of Ash & Sold & Some Sold & Sold \\
\hline Typical Inlet Mercury $(\mu g / d n c m)$ & $6-7$ & $11.1-13.5$ & $11.1-13.4$ \\
\hline Typical Mercury Removal & $10 \%-20 \%$ & $0 \%-10 \%$ & $0 \%-10 \%$ \\
\hline
\end{tabular}

Table 2. Field-Testing Schedule.

\begin{tabular}{|l|l|l|l|l|l|l|l|l|l|}
\hline \multirow{2}{*}{ Site } & \multicolumn{2}{|c|}{2005} & \multicolumn{5}{c|}{ 2006 } & \multicolumn{3}{c|}{2007} \\
\cline { 2 - 10 } & Q3 & Q4 & Q1 & Q2 & Q3 & Q4 & Q1 & Q2 & Q3 \\
\hline Louisa & & & & & & & & & \\
\hline Independence & n & & & & & & & & \\
\hline $\begin{array}{l}\text { Council } \\
\text { Bluffs }\end{array}$ & & & & & & & & & \\
\hline
\end{tabular}


The primary funding for testing at Louisa is through U.S. DOE Cooperative Agreement No. DE-FC26-05NT42307. Almost twenty-eight percent of the funding is through industry participants including:

- EPRI

- ADA-ES, Inc.

- SCS

- DTE Energy

- MidAmerican - Louisa Generating Station (host site)

Key members of the test team include:

ADA-ES, Inc.

EPRI

Others

Stack test firms

Analytical laboratories

\section{Site Testing Overview}

Louisa Generating Station is configured with a hot-side ESP. It was identified as one of the high-temperature sorbent test sites because it currently uses a flue gas conditioning agent, ADA-37, to enhance particulate removal in the ESP. Results of testing for the EPA's most recent mercury Information Collection Request (ICR) at the Alliant Columbia Generating Station show mercury removal of up to 32\% while conditioning the ESP with ADA-37. This is higher native mercury removal than for any of the other hot-side plants in the ICR database. Tests were planned at Louisa to determine the potential of ADA-37 for mercury trim control.

The site set-up activities started on January 25, 2006, with equipment setup, and concluded on February 13, 2006. ADA-37 flue gas conditioning reagent was injected using the existing injection grid throughout the test program. The injection lances were cleaned several weeks prior to this testing during a routine plant outage. During a portion of the test program, ALSTOM's KNX material, a bromine-based coal additive, was applied to the coal through a temporary injection system at the coal gravimetric feeders.

Mercury measurements were made using a semi-continuous emission monitor (SCEM) at the ESP inlet, a mercury continuous emissions monitor (Hg CEM) at the stack, the dry sorbent trap method (STM) at the stack, and analysis of coal and ash samples. 


\section{PROJECT OBJECTIVES AND TECHNICAL APPROACH}

The general approach for the field-testing at Louisa was to follow a series of three tasks: 1) Sample and Data Collection Coordination, 2) Baseline Tests, and 3) Parametric Tests.

The objectives of these tests were to evaluate the following:

- $\quad$ Baseline, native mercury capture.

- Potential of the existing flue gas conditioning reagent, ADA-37, to increase mercury removal across the ESP.

- Mercury speciation change when applying an additive, ALSTOM KNX, to the coal prior to entering the pulverizers and furnace.

\section{Importance of Testing at Louisa}

Available data indicate that mercury removal across a hot-side ESP is limited. Some data suggest that the flue-gas conditioning agent ADA-37 may increase mercury in these units. This test program fills a data gap for the industry. 


\section{LOUISA GENERATING STATION SITE DESCRIPTION}

\section{General Description of Unit 2}

The test unit (Unit 2) is a single 700-MW PRB coal-fired electric generating unit. The unit typically fires PRB coal in a balanced draft Babcock \& Wilcox opposed wall fired boiler. The Research-Cottrell hot-side ESP is followed by two Ljungström regenerative air heaters. Key operating parameters for Louisa Unit 2 are shown in Table 3. A general sketch of the flue gas flow is shown in Figure 1.

The ESP configuration for Louisa Unit 2 has four boxes in a split wedge arrangement, with each box consisting of 27 transformer/rectifier (TR) sets, 3 chambers, 51 gas passages, 5 electrical fields and 8 bus sections. A sketch of the ESP showing the TR sets and electrical fields is shown in Figure 2.

Table 3. Louisa Key Operating Parameters.

\begin{tabular}{|l|c|}
\hline Unit & 1 \\
\hline Size (MWnet) & 700 \\
\hline Test Portion (MWe) & 700 \\
\hline Coal & PRB \\
\hline Heating Value (as received) & 8500 \\
\hline Sulfur (\% by weight) & 0.32 \\
\hline Chlorine (\%) & $\sim 0.01$ \\
\hline Mercury $(\mu \mathrm{g} / \mathrm{g})$ ) & 0.08 \\
\hline Particulate Control & Compliance Coal \\
\hline Sulfur Control & Regenerative \\
\hline Air Preheater & Sold \\
\hline Ash Reuse & \\
\hline
\end{tabular}




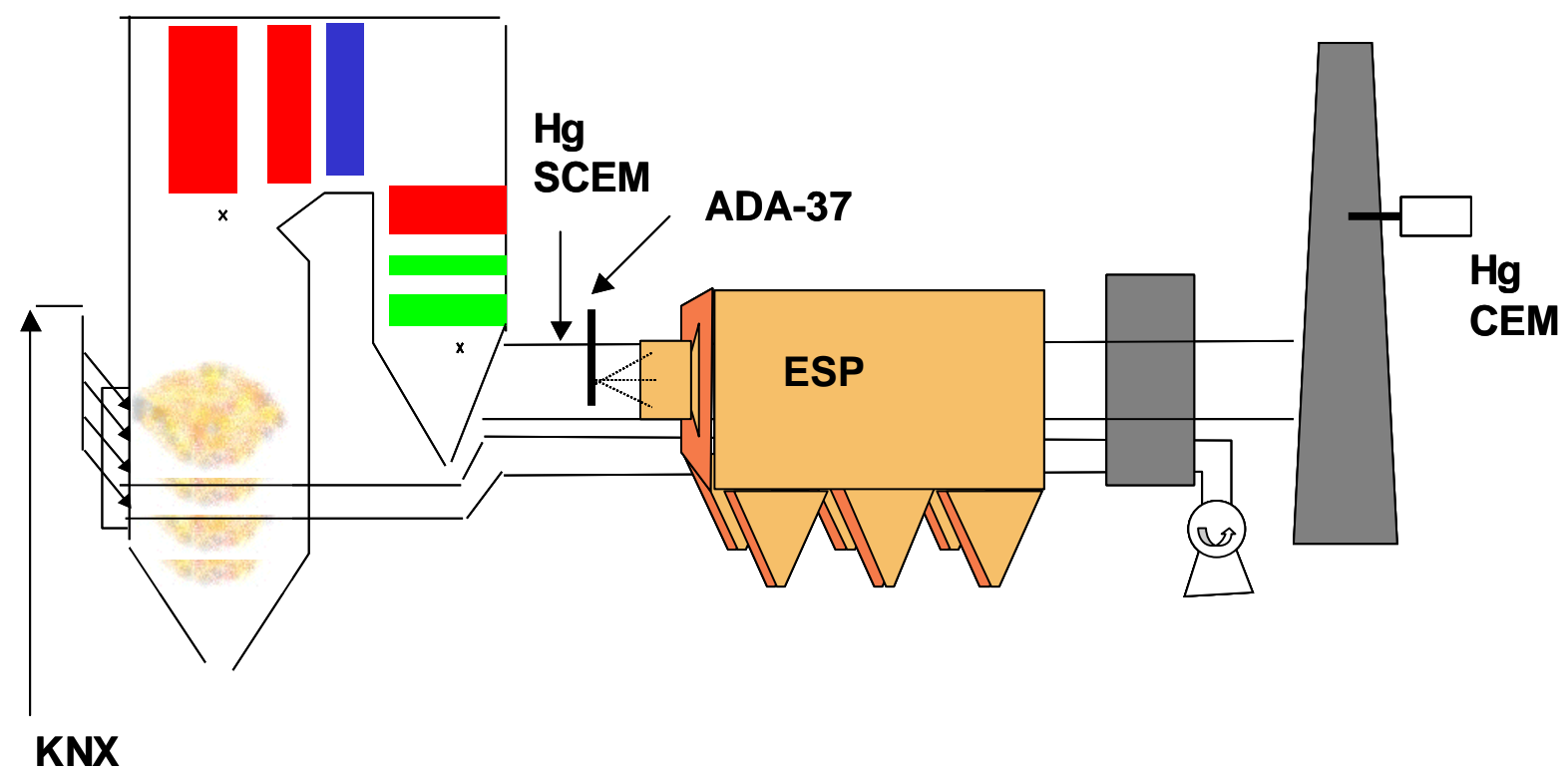

Figure 1. Sketch of Louisa Unit 2 General Configuration.

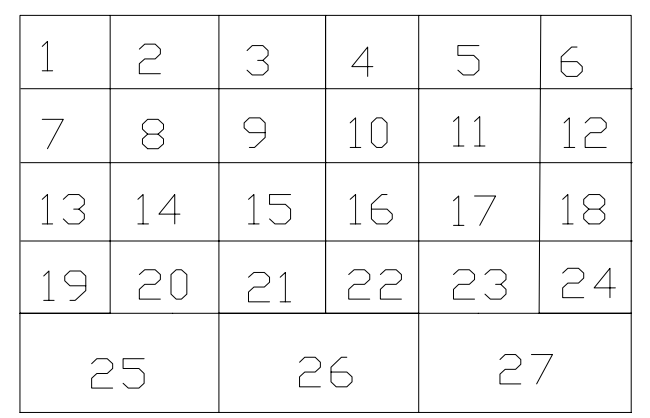

Figure 2. Single ESP Box Electrical Field Configuration.

Because Louisa sells its fly ash, it was important that the reagents used during testing would not impact the marketability of the fly ash. The reagents tested at Louisa should have no impact on ash sales.

For collection of plant operating data, the plant installed a workstation in the ADA-ES testing office trailer that was connected to the plant control and information system. 


\section{Description of Sorbent Injection and Mercury Monitoring Locations}

During the test program, the liquid reagent ADA-37 was injected upstream of the ESP using existing injection lances. One hundred percent of the Unit 1 flue gas flow was treated. For a portion of the tests, ALSTOM's KNX coal additive was added to the coal prior to combustion. The unit has seven pulverizers. KNX was injected into the feeders on four of the mills (mills 101, 102, 103, and 104). KNX-treated coal was delivered to four burner elevations - two on the front wall and two on the rear wall—which should have provided relatively uniform distribution within the furnace. A diagram of the boiler showing the burner arrangement and the associated coal mill for each burner level is shown in Figure 3.

Two mercury monitors were installed for this program. An SCEM was installed in a port upstream of one pair of ESP boxes. An Hg CEM was installed at the 400-foot test elevation in the Unit 1 stack. 


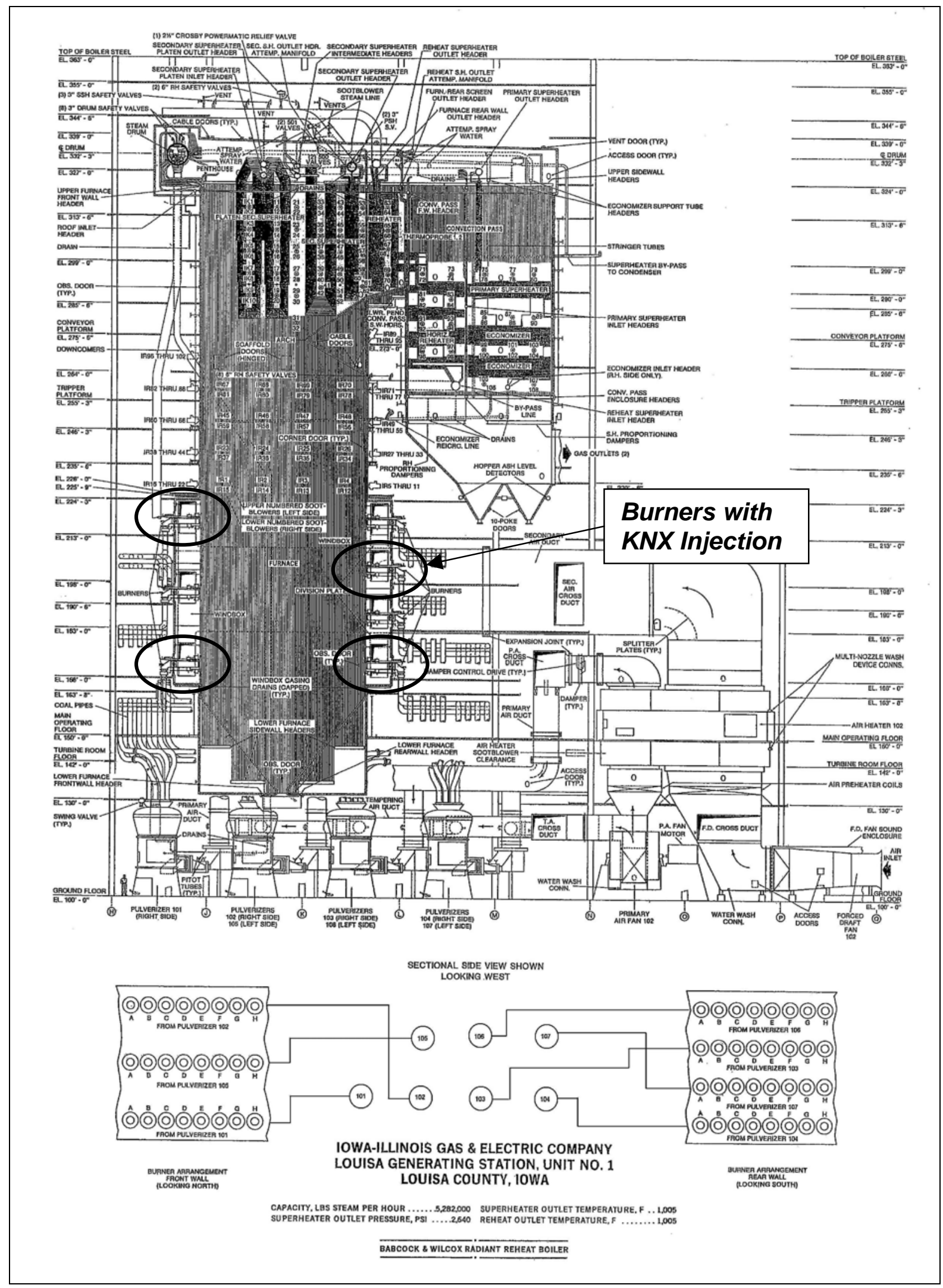

Figure 3. Louisa Boiler Arrangement Indicating Burners with KNX-Treated Coal. 


\section{EQUIPMENT DESCRIPTIONS}

\section{ADA-37 Injection System}

The reagent injection system currently in use at Louisa consists of a bulk-storage vessel and a single feeder/metering train. A photo of the ADA-37 injection skid is shown in Figure 4.
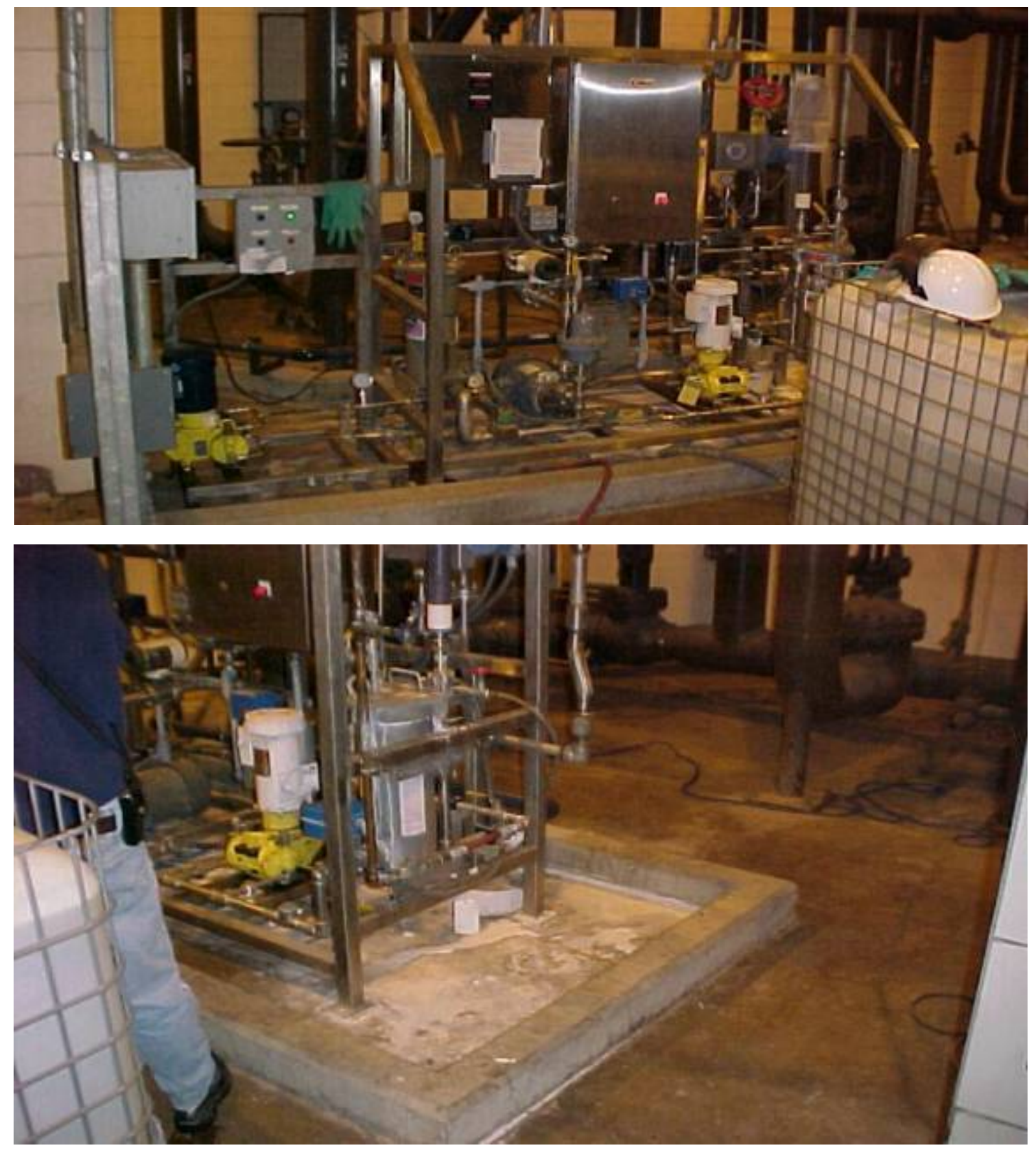

Figure 4. ADA-37 Injection Skid Installed at Louisa Generating Station. 
Two sets of injection grids, one for each ESP path, are installed on Unit 1. Each grid consists of six injection lances connected by a common header located upstream of the ESPs. A programmable logic controller (PLC) system controls the system operation. The sorbent injection system allows controlling the reagent feed rate either manually through a HumanMachine Interface (HMI), or automatically through a load-following signal from the plant such as unit MW load or flue gas flow rate.

Bulk delivery trucks deliver and unload the ADA-37 flue gas conditioning reagent into a storage vessel near the skid. The reagent is delivered from the bottom of the storage vessel through a metering system and then into the feed system. The reagent is mixed with dilution water, which is then transported to the injection grid. Atomizing air is used to create the maximum efficiency droplet size for distribution.

\section{ALSTOM KNX Injection System}

The ALSTOM KNX liquid delivery system consists of a 55-gallon drum with a feed line to a variable speed positive displacement pump. KNX was delivered to the coal at the gravimetric feeders via flex tubing.

\section{Mercury Monitoring System}

Two mercury monitors were used during testing at Louisa. One was an SCEM built and operated by Apogee Scientific, Inc. One was a continuous emissions monitor (CEM) built by Thermo Electron Corporation and operated by ADA-ES. The SCEM was installed at the inlet to the ESP upstream of sorbent injection. The CEM was installed at the stack. The SCEM consisted of a cold-vapor atomic absorption spectrometer (CVAAS) coupled with a gold amalgamation system (Au-CVAAS). A similar SCEM is shown in Figure 5. The CEM uses a dilution probe followed by a cold-vapor atomic fluorescence spectrometer (CVAFS). Both systems used inertial separation probes to separate the particulate-free sample gas from the bulk flue gas.

Both analyzers are capable of measuring total vapor-phase mercury and elemental vapor-phase mercury. The analyzer determines total vapor-phase mercury concentrations by reducing all of the oxidized mercury to the elemental form near the extraction location. To measure elemental mercury, the oxidized mercury is removed while allowing elemental mercury to pass through without being altered. 


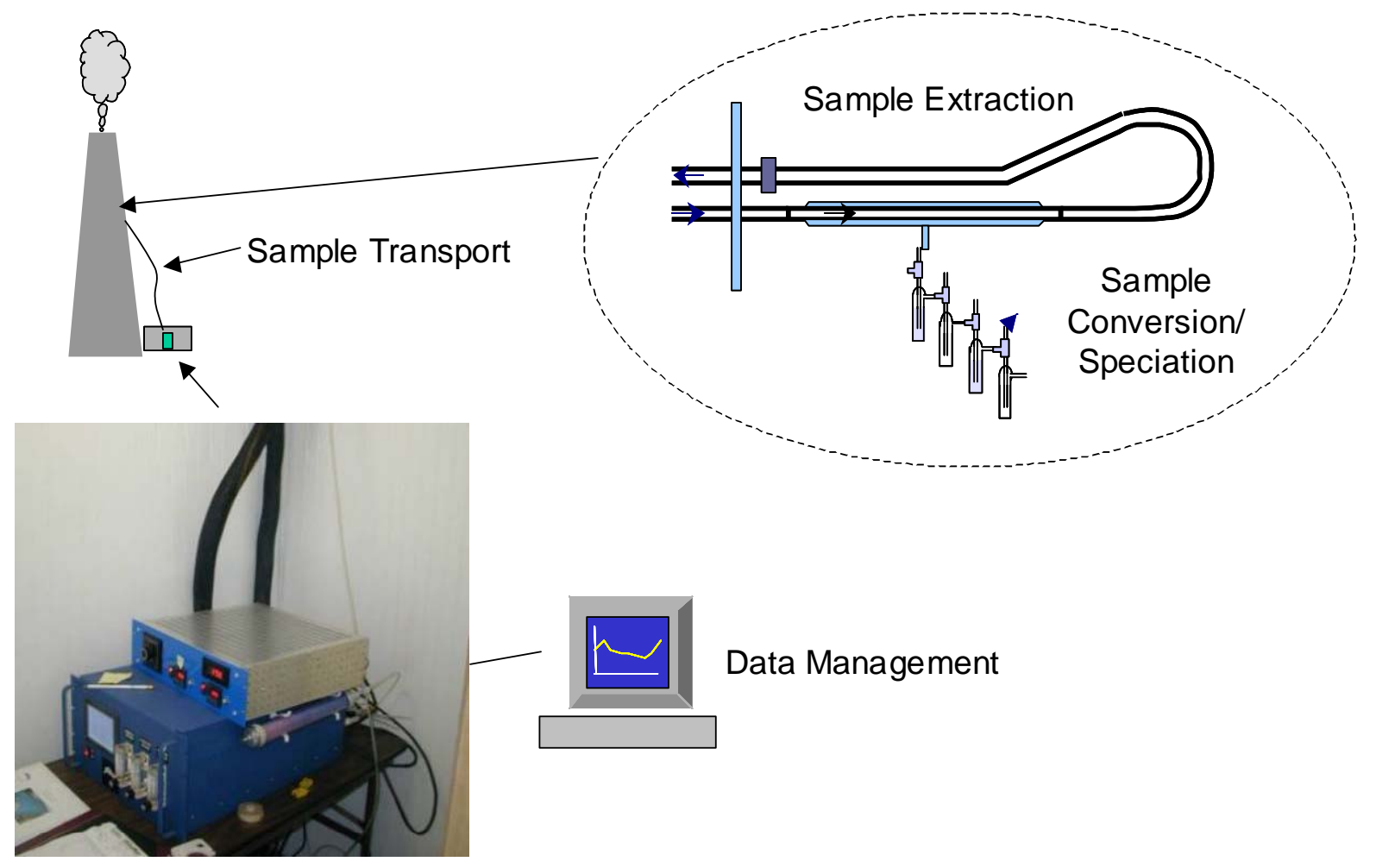

Figure 5. Sketch of SCEM Mercury Measurement System. 


\section{TEST PROGRAM DESCRIPTION}

\section{Description of Field-Testing Tasks}

The field tests were accomplished through a series of three subtasks:

1. Sample and Data Collection Coordination

2. Baseline Tests

3. Parametric Tests

The subtasks are independent from each other in that they each have specific goals and tests. However, they are also interdependent, as the results from each task influenced the test parameters of subsequent tasks. A summary of each subtask is presented in the following sections.

\section{Sample and Data Collection Coordination}

Collecting, analyzing, and archiving samples and plant operating data are key aspects of any field test program. A copy of the Sample Collection and Management Plan for the test program at Louisa is included in Appendix B. An example of samples and data collected during testing is presented in Table 4.

Table 4. Data Collected during Field Testing.

\begin{tabular}{|c|c|c|c|}
\hline Parameter & Sample/Signal/Test & Baseline & Parametric \\
\hline Coal & Batch sample & Yes & Yes \\
\hline Coal & $\begin{array}{r}\text { Plant signals: burn rate (lb/hr) } \\
\text { quality (lb/MMBTU, \% ash) }\end{array}$ & Yes & Yes \\
\hline Fly ash & Batch sample & Yes & Yes \\
\hline Unit operation & Plant signals: boiler load, etc. & Yes & Yes \\
\hline Temperature & Plant signal at $\mathrm{AH}$ inlet and stack & Yes & Yes \\
\hline $\begin{array}{l}\text { Mercury } \\
\text { (total and speciated) }\end{array}$ & Hg monitors at ESP inlet/outlet & Yes & Yes \\
\hline $\begin{array}{r}\text { Mercury } \\
\text { (total) }\end{array}$ & $\begin{array}{l}\text { STM (modified } 40 \text { CFR, Part 75, } \\
\text { Appendix K) }\end{array}$ & Yes & Yes \\
\hline $\mathrm{HCl}, \mathrm{HF}, \mathrm{Br}$ & EPA Method 26a at ESP outlet & Yes & Yes \\
\hline Sorbent Injection Rate & ADA-37 and KNX injection pumps, gph & No & Yes \\
\hline $\begin{array}{l}\text { Plant CEM data } \\
\left(\mathrm{NO}_{\mathrm{x}}, \mathrm{O}_{2}, \mathrm{SO}_{2}, \mathrm{CO}\right)\end{array}$ & Plant data - stack & Yes & Yes \\
\hline Stack Opacity & Plant data - stack & Yes & Yes \\
\hline Pollution Control Equipment & $\begin{array}{l}\text { Plant data } \\
\text { (Sec mA, Sec. Voltage, Sparks, etc.) }\end{array}$ & Yes & Yes \\
\hline
\end{tabular}

Coal samples were collected daily and provided for analysis. Grab samples of ash were collected from the ESP hoppers each day of testing. 


\section{Overview of Test Program Sequence}

Equipment installation began on January 25, 2006. During the following four days, mercury SCEM and CEM analyzers were installed and operationally tested in preparation for the testing program.

Hg CEM measurements started as planned on January 28, 2006. The location of the Thermo Hg CEM was in the annular space between the chimney and the liner at the 400 -foot emissions monitoring elevation on the stack. Due to the varying ambient conditions at that location, the first readings from the Thermo Hg analyzer were erratic. Subsequent modifications to this area stabilized the temperatures, which resulted in more stable operation and data from the analyzer. Stable data collection started on February 1, 2006.

\section{Baseline and Parametric Testing (No Sorbent Injection)}

Approximately 92 hours of baseline data were collected during this test program. During the baseline period, ADA-37 injection was turned off to evaluate the impact on native mercury removal. Mercury measurements were made upstream of the reagent injection location and at the main stack. The unit was operated at conditions expected during the parametric tests. This included operating the boiler at full-load and load-following conditions, and operating the ESP equipment under standard operating conditions.

\section{Parametric Testing}

Eleven days of parametric testing were conducted. The goal of the parametric test sequence was to develop a relationship between reagent injection concentration and mercury removal efficiencies across the ESP. During the first six days of parametric testing, the ADA-37 injection rate was adjusted for 6, 12, and 18 gallons per hour with two days at each injection concentration. During three days of parametric testing, the effect of KNX injection on mercury removal and speciation was evaluated with and without ADA-37 injection. In addition to mercury concentrations, the correlation between reagent injection rate and ESP operation (power, spark rate, etc., and particulate emissions from the ESP) was also evaluated.

EPA M26A measurements were made during the KNX injection sequence to compare the halogens in the flue gas during normal ADA-37 injection and when adding bromine to the coal in the form of KNX. 


\section{RESULTS FROM LOUISA TESTING}

\section{Mercury Removal Results}

Baseline testing (no ADA-37 or KNX injection) was conducted January 31 through February 2 and February 12 through 13, 2006. ADA-37 testing was conducted February 3 through 8, 2006, and KNX evaluations were conducted February 9 through 11, 2006.

\section{ADA-37 Tests}

The ADA-37 testing consisted of injecting the flue gas conditioning reagent at rates of 6,12 , and 18 gallons per hour for two days per rate and observing the change in mercury levels across the ESP. Mercury removal trends are presented in Figure 6. The data suggest that there was no change in mercury removal with varying ADA-37 injection rates, including periods with no injection. The flue gas temperature at the inlet to the air preheater was typically between 780 and $800^{\circ} \mathrm{F}$ during full-load conditions. There was fairly good correlation between the analyzer and STM measurements.
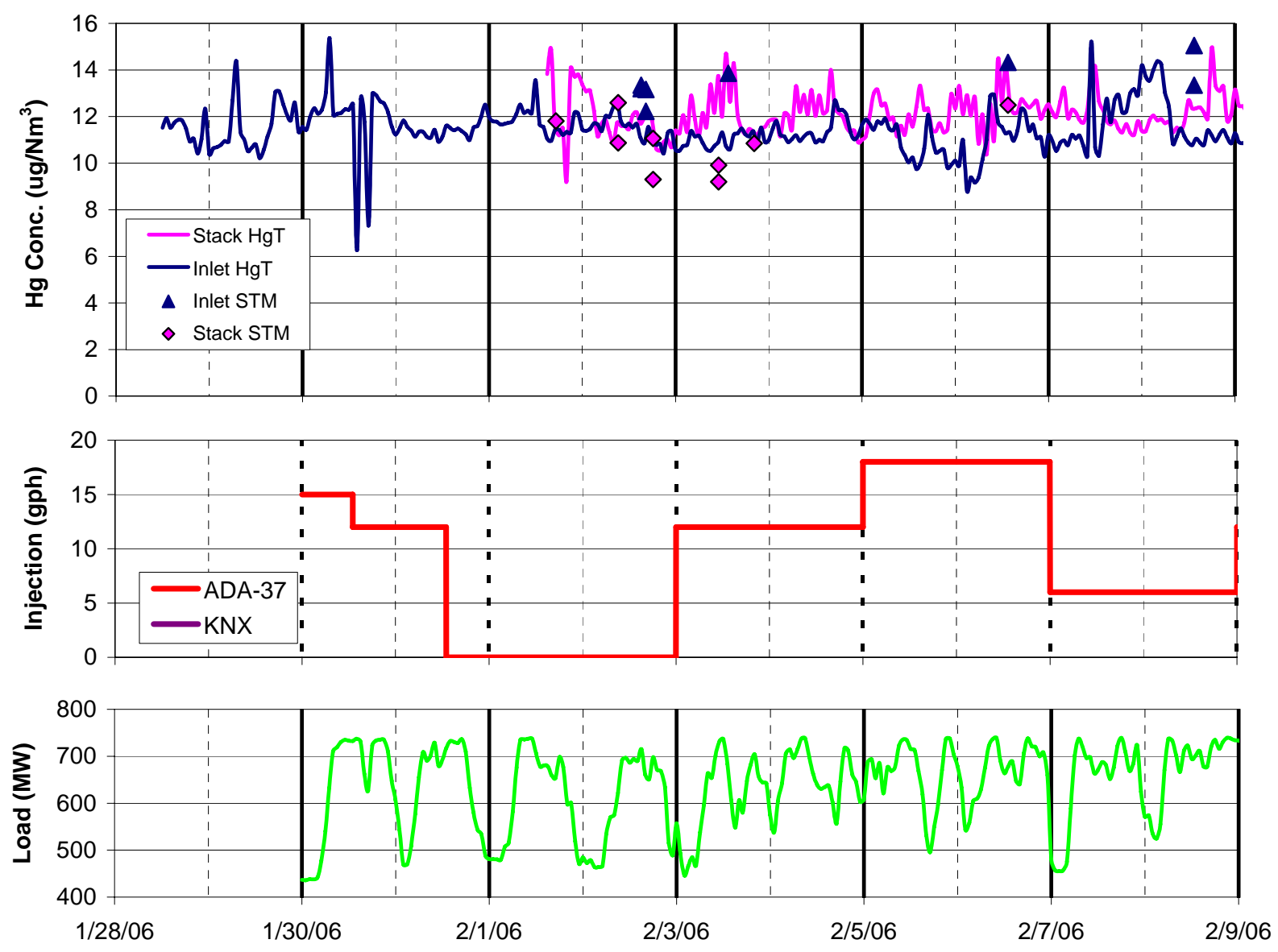

Figure 6. Mercury Removal Trends during Baseline and ADA-37 Testing. 


\section{ALSTOM KNX Tests}

The addition of KNX to the coal appeared to increase the fraction of oxidized mercury at both the inlet to the ESP and the stack. At an injection rate of 3 gallons per hour, the fraction of oxidized mercury at the inlet to the ESP increased from less than $15 \%$ to between 30 and $45 \%$. At 8 gallons per hour KNX, the fraction of oxidized mercury at the inlet to the ESP was nearly $50 \%$. At the stack, the fraction of oxidized mercury was between 30 and $50 \%$ without KNX, 68 to $77 \%$ at 3 gallons per hour, and over $80 \%$ at 8 gallons per hour. These trends are shown in Figure 7.

The addition of KNX did not change the mercury removal across the ESP. The increased fraction of oxidized mercury may be beneficial if Louisa were configured with a wet scrubber. In this case, a portion of the oxidized mercury may be removed in the scrubber.
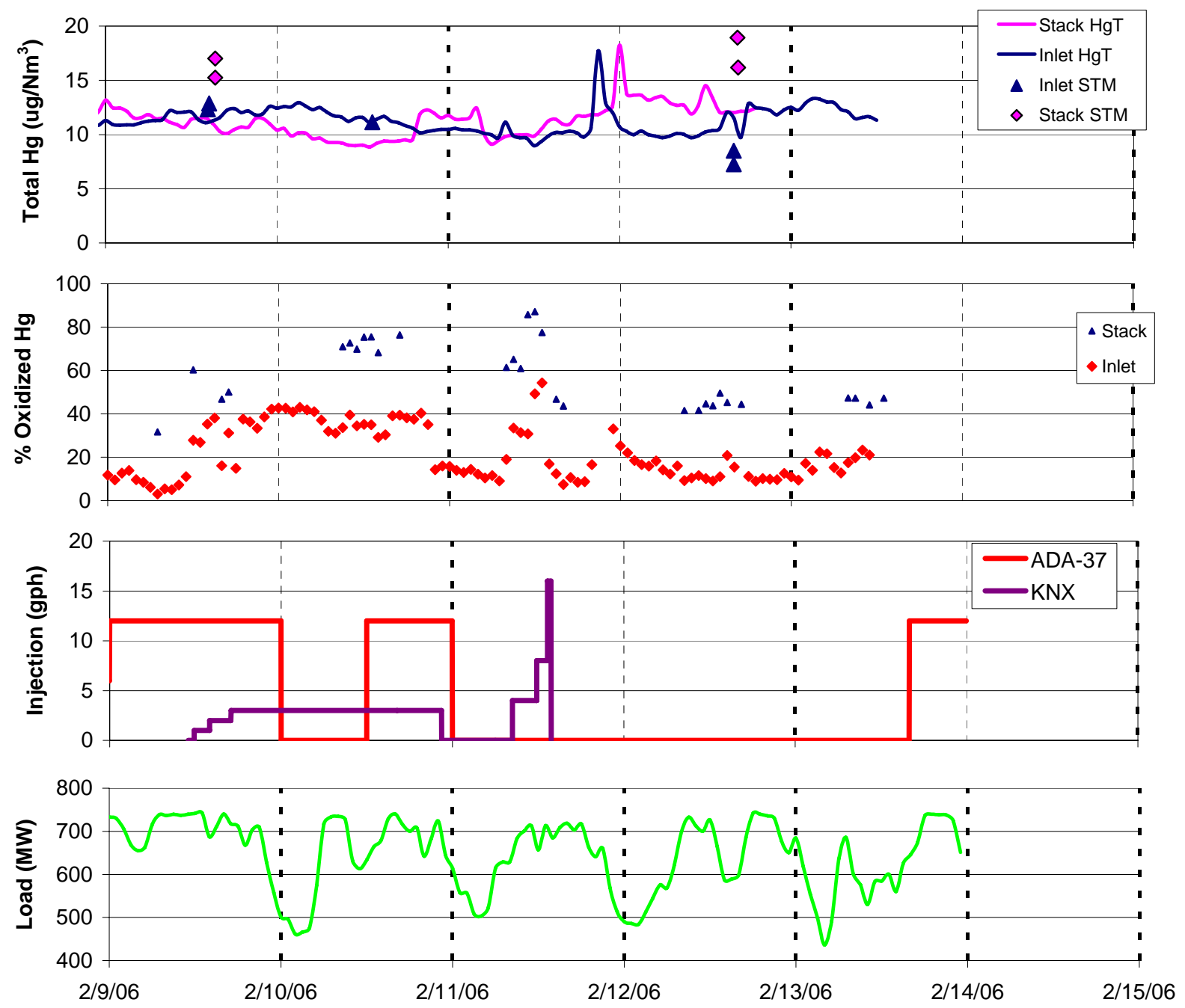

Figure 7. Mercury Speciation and KNX Injection Rate. 


\section{Coal and Ash Analyses}

Results from as-fired coal samples collected on February 4 and 9, 2006, are shown in Tables 5 and 6. These data indicate that the coal fired at Louisa during testing was fairly typical for PRB coal.

Table 5. Louisa Unit 2 Coal Analysis, Dry Basis.

\begin{tabular}{|l|c|c|}
\hline & $\mathbf{2 / 4 / 0 6}$ & $\mathbf{2 / 9 / 0 6}$ \\
\hline Ultimate & & \\
\hline Carbon & & 70.29 \\
\hline Hydrogen & & 5.03 \\
\hline Nitrogen & & 1.02 \\
\hline Sulfur & & 0.48 \\
\hline Ash & & 6.95 \\
\hline Oxygen & & 16.23 \\
\hline Proximate & & \\
\hline Ash & 7.83 & 6.95 \\
\hline Volatile & 41.46 & 41.63 \\
\hline Fixed Carbon & 50.71 & 51.42 \\
\hline HHV (BTU/lb) & 11975 & 11996 \\
\hline Hg (ppb) & 118 & 130 \\
\hline Hg (lb/TBtu) & 9.85 & 10.8 \\
\hline
\end{tabular}

Table 6. Mineral Analysis of Ashed Coal, 2/9/06 Sample.

\begin{tabular}{|l|c|}
\hline Mineral & Concentration $(\boldsymbol{\mu g} / \mathbf{g})$ \\
\hline $\mathrm{Ag}$ & $<0.2$ \\
\hline $\mathrm{As}$ & 1100 \\
\hline $\mathrm{Ba}$ & 0.40 \\
\hline $\mathrm{Be}$ & $<0.2$ \\
\hline $\mathrm{Cd}$ & 3.00 \\
\hline $\mathrm{Co}$ & 4.00 \\
\hline $\mathrm{Cr}$ & 12.00 \\
\hline $\mathrm{Cu}$ & 10.00 \\
\hline $\mathrm{Mn}$ & 4.00 \\
\hline $\mathrm{Ni}$ & $<2$ \\
\hline $\mathrm{Pb}$ & $<1$ \\
\hline $\mathrm{Sb}$ & 1.00 \\
\hline $\mathrm{Se}$ & $<1$ \\
\hline $\mathrm{Tl}$ & 15.00 \\
\hline $\mathrm{V}$ & 3.00 \\
\hline $\mathrm{Zn}$ & \\
\hline
\end{tabular}


Fifteen ash samples were collected from the Row 1 hoppers on ESP 101 and 104 (thirty samples total). The highest fraction of LOI measured during the program was $0.18 \%$. The average LOI was $0.11 \%$. The mercury concentrations measured in the ash samples were all below $10 \mathrm{ng} / \mathrm{g}$. This confirms that there was no mercury removal in the hot-side ESP.

\section{ESP Performance}

The normal flue gas conditioning injection rate is 12 gallons per hour, which the plant injects at a constant rate independent of unit load. During this program, ADA-37 was shut off for periods up to 56 hours and injection rates of 6,12 , and 18 gallons per hour were tested for 48-hour increments. The ESP had come offline for a cleaning just prior to the DOE test program and there was sufficient ESP preconditioning so that the plant did not see any change in ESP performance or plant opacity when operating with no reagent injection. A trend of stack opacity is shown with ADA-37 and KNX injection rates in Figure 8 for reference.
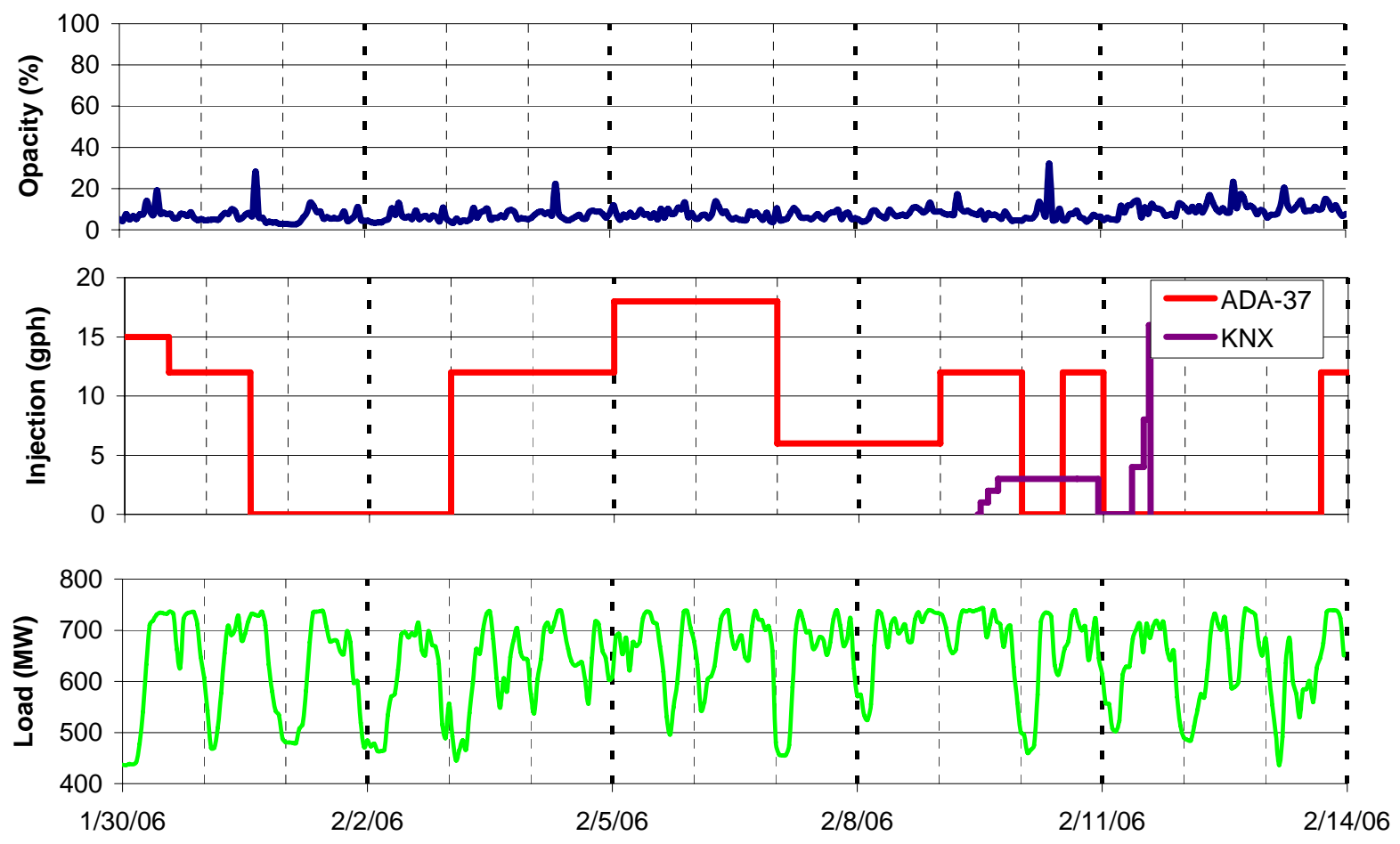

Figure 8. Opacity Trends during Parametric Testing. 


\section{Results of EPA M26A Testing}

EPA M26A measurements were made on February 8 and 9, 2006, to determine whether the introduction of KNX onto the coal resulted in an increase in bromine emissions at the stack. Results from these tests indicate that there was no measurable increase in bromine emissions during KNX testing. These results are shown in Figure 9. The full M26A report is included in Appendix C.

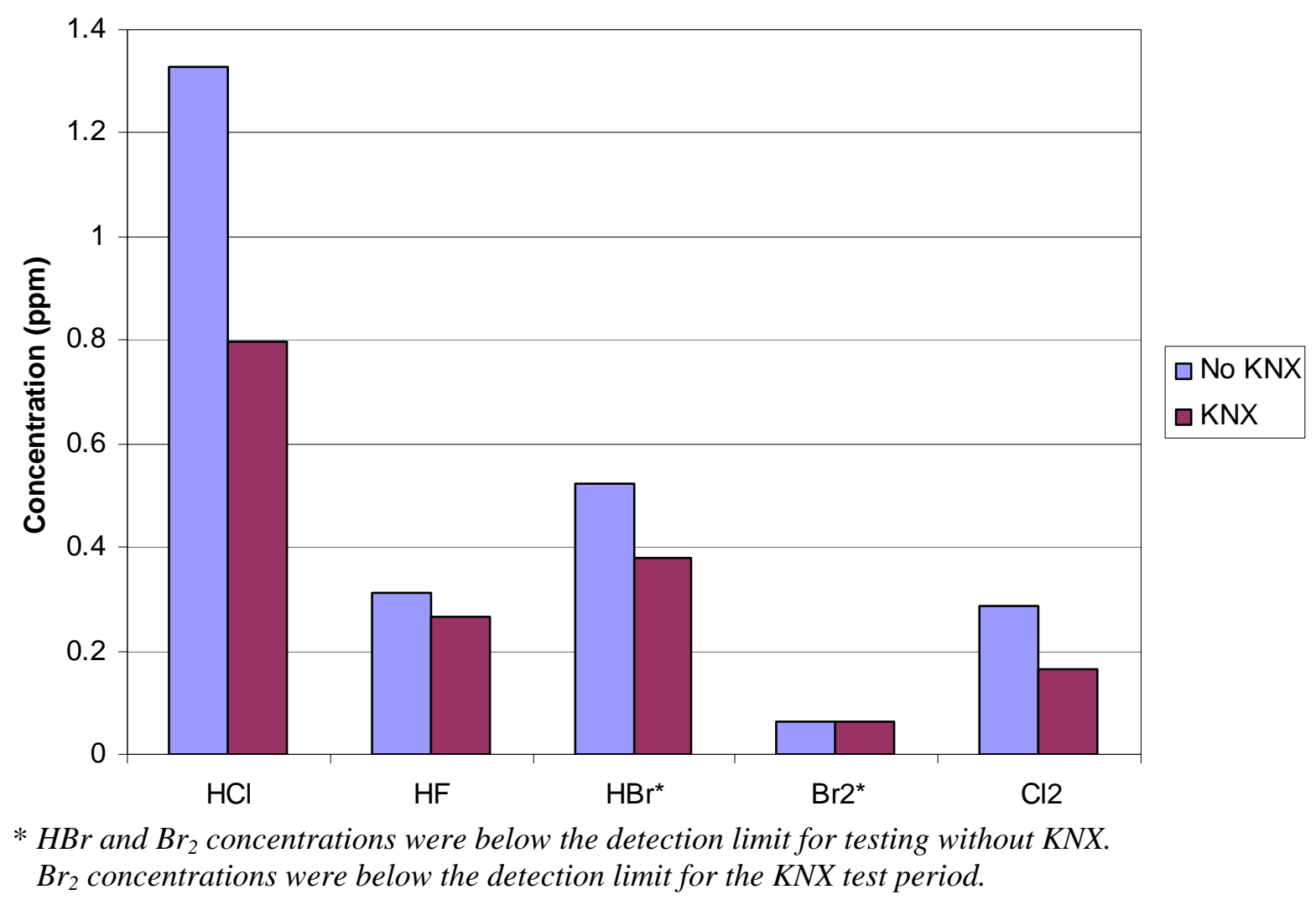

Figure 9. Results from EPA M26A Measurements at Louisa. 


\section{CONCLUSIONS}

Testing was conducted from January 28 to February 13, 2006, to evaluate the mercury removal effectiveness of the hot-side ESP flue gas conditioning agent, ADA-37, currently in use at Louisa and any synergistic effects of ALSTOM's coal additive, KNX.

Results indicate that ADA-37 is not effective at removing mercury across the hot-side ESP at Louisa at injection rates up to 18 gallons per hour. KNX appeared to increase the fraction of oxidized mercury, but no net increase in mercury removal was noted with KNX. The plant burned the normal subbituminous PRB fuel during the test program.

No impacts on ESP performance were noted as a result of changing the ADA-37 injection concentration. However, the ESP had come offline for a cleaning just prior to the DOE test program and there was sufficient ESP preconditioning so that the plant did not see any change in plant opacity when operating with no reagent injection during the relatively short parametric test period. 


\section{APPENDIX A}

\section{Louisa Test Plan}




\section{DOE NATIONAL ENERGY TECHNOLOGY LABORATORY MERCURY FIELD EVALUATION}

Evaluation of High Temperature Liquid Sorbent Injection for Mercury Control at MidAmerican's Louisa Generating Station

Test Plan

For:

MidAmerican Energy Company

DOE NETL

EPRI

By:

ADA Environmental Solutions, Inc.

8100 SouthPark Way, Unit B

Littleton, CO 80120

December 14, 2005 


\section{Table of Contents}

Project Objectives ...................................................................................................................... 1

Project Overview............................................................................................................................ 2

Host Site Description ................................................................................................................ 3

General Technical Approach ............................................................................................. 6

Task 1. Site Coordination, Kickoff Meeting, Test Plan, and QA/QC Plan ........... 6

Task 2. Design and Install Site-Specific Equipment ..................................................... 7

Task 3. Field-Tests - Sorbent Selection .......................................................................... 11

Task 4. Field-Tests - Baseline Tests ............................................................................... 13

Task 5. Field-Tests - Parametric Tests ........................................................................... 14

Task 6. Field-Tests - Long-Term Tests....................................................................... 15

Task 7. Data Analysis ........................................................................................................... 15

Task 8. Sample Evaluation..................................................................................... 15

Task 9. Site Report.................................................................................................................... 16

Task 10. Technology Transfer ................................................................................. 16

Task 11. Management and Reporting............................................................................. 17

Schedule ........................................................................................................................................... 18 


\section{List of Figures}

Figure 1. High Temperature Liquid Injection Process Diagram. ................................... 2

Figure 2. Sketch of Plant Process at Louisa Unit 1.................................................. 5

Figure 3: ESP Electrical Field Configuration. ....................................................... 5

Figure 4: Flue Gas Conditioning System Injection Skid and Feeder System Installed at MidAmerican's Louisa Generating Station.................................................................... 9

Figure 5: Sketch of Mercury Measurement System................................................. 11

Figure 6: Current Schedule for the Louisa Test Program.................................................... 18

\section{List of Tables}

Table 1. Host Sites Participating in the Sorbent Injection Demonstration Project......... 3

Table 2. Louisa Key Operating Parameters. ........................................................................ 4

Table 3. Site-Specific Tasks..................................................................................................... 6

Table 4. Scopes of Work for Reagent System........................................................... 8

Table 5. Full-Scale Test Sequence. ........................................................................................ 12

Table 6: Test Matrix for Baseline and Parametric Test Series ...................................... 12

Table 7: Key Project Personnel for Louisa Mercury Field Evaluation............................ 19 


\section{Project Objectives}

The objective of testing at MidAmerican Energy Company's Louisa Generating Station is to determine the cost and effects of reagent injection using ADA-ES's high temperature liquid injection process for control of mercury in stack emissions.

The benefit of the high temperature liquid injection process, shown in Figure 1, High Temperature Liquid Injection Process Diagram, is that the existing ESP collects the majority of ash and mercury while the flue gas is hot, potentially minimizing or eliminating the need for adding a particulate collection device downstream of the air pre-heater when the flue gas is cooler and existing technologies are available to control mercury emissions. With high temperature liquid injection, the reagent/sorbent injection is upstream of the existing hot side electrostatic precipitator (ESP). This process, not involving activated carbon, allows the ash collected in the ESP fields to continue to be sold for use in concrete.

Even though this evaluation will inject reagent into the entire hot-side ESP, mercury measurements will be sampled from one-half of the $700 \mathrm{MW}$ flue gas stream from Unit 1. The inlet will be sampled upstream of one of the two hot side ESP units, the outlet will be sampled at the stack. Some consideration is being given to sampling downstream of the ESP to evaluate speciation changes caused by the reagent injection. 


\section{Air Compressor}

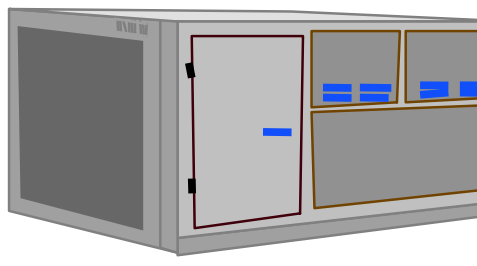

$\sqrt{1}$

\section{Electrostatic} Precipitator
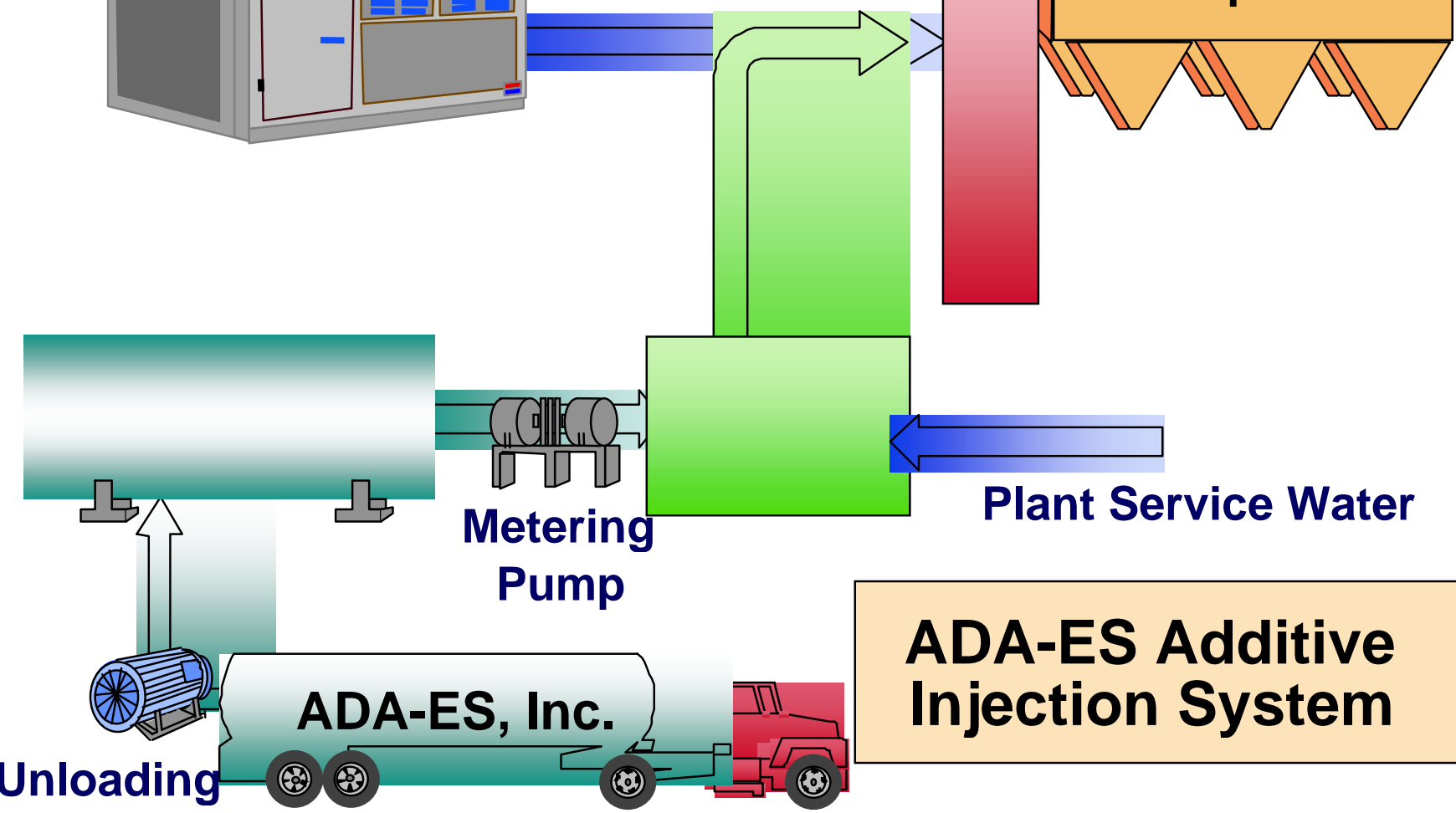

Pump

Figure 1. High Temperature Liquid Injection Process Diagram.

\section{Project Overview}

The Louisa test program is part of a four-site program funded by the Department of Energy's National Energy Technology Laboratory (DOE/NETL) and industry partners to obtain the necessary information to assess the feasibility and costs of controlling mercury from coal-fired utility plants using either high temperature sorbents or EPRI's TOXECON II ${ }^{\mathrm{TM}}$ process. Table 1, Host Sites Participating in the Sorbent Injection Demonstration Project, shows the host sites for this program's testing. Testing at these four host sites will allow documentation of sorbent performance on the following configurations: 
Table 1. Host Sites Participating in the Sorbent Injection Demonstration Project.

\begin{tabular}{|l|l|l|l|l|}
\hline & $\begin{array}{l}\text { Coal / } \\
\text { Options }\end{array}$ & APC & $\begin{array}{l}\text { Capacity (MW) / } \\
\text { Test Portion }\end{array}$ & $\begin{array}{l}\text { Current Hg } \\
\text { Removal (\%) }\end{array}$ \\
\hline $\begin{array}{l}\text { Entergy's Independence } \\
\text { Plant Unit 2 }\end{array}$ & PRB & Cold-Side ESP & $842 / 106$ & $10-20 \%$ \\
\hline $\begin{array}{l}\text { MidAmerican's Louisa } \\
\text { Generating Station Unit 1 }\end{array}$ & PRB & Hot-Side ESP & $700 / 700$ & $\begin{array}{l}<10 \% \\
\text { (Estimated) }\end{array}$ \\
\hline $\begin{array}{l}\text { MidAmerican's Council } \\
\text { Bluffs Energy Center Unit } \\
\mathbf{2}\end{array}$ & PRB & Hot-Side ESP & $88 / 88$ & $\begin{array}{l}<10 \% \\
\text { (Estimated) }\end{array}$ \\
\hline $\begin{array}{l}\text { AEP's Gavin Station Unit } \\
\mathbf{1} \text { or } 2\end{array}$ & Bit & $\begin{array}{l}\text { Cold-Side ESP / } \\
\text { FGD }\end{array}$ & $1,200 / 200$ & $\begin{array}{l}\text { 40\% ESP } \\
\text { (Est), 70\%+ } \\
\text { in FGD }\end{array}$ \\
\hline
\end{tabular}

The test program selected Louisa Unit 1 as one of the test sites because it's flue gas conditioning system injects a high temperature reagent which has been shown to remove $30 \%$ of the mercury in flue gas at a cost of $\$ 700 \mathrm{~K}$ per year for a $500-\mathrm{MW}$ PRB plant. This cost is $20 \%$ of what DOE and EPA projections indicated for a coldside electrostatic precipitator (ESP) plant this size. This combination will allow an evaluation of the high temperature liquid injection process to take advantage as much as possible of existing equipment and minimize the need for installing new major capital equipment.

\section{Host Site Description}

The Louisa Generating Station is located in Louisa County, lowa near Muscatine, lowa. Unit 1 is a 700-MW (net) pulverized coal electric generating unit with Lungstrum regenerative air preheaters that burns PRB coal. Table 2, Louisa Key Operating Parameters, shows the key operating parameters for Louisa Unit 1. 
Test Plan

Table 2. Louisa Key Operating Parameters.

\begin{tabular}{|l|c|}
\hline Unit & 1 \\
\hline Size (MWnet) & 700 \\
\hline Test Portion (MWe) & 700 \\
\hline Coal & PRB \\
\hline Heating Value (as received) & 8,500 \\
\hline Sulfur (\% by weight) & 0.32 \\
\hline Chlorine (\%) & $\sim 0.01$ \\
\hline Mercury ( $\mu \mathrm{g} / \mathrm{g})$ & 0.08 \\
\hline Particulate Control & Hot-Side ESP \\
& SCA $=459 \mathrm{ft}^{2} / \mathrm{kacfm}$ \\
\hline Sulfur Control & Compliance Coal \\
\hline Air Pre-Heater & Regenerative \\
\hline Ash Reuse & Sold \\
\hline
\end{tabular}

Louisa Unit 1 is equipped with four ESP units operating in a split wedge arrangement for particulate removal. Figure 2, Sketch of the Plant Process at Louisa Unit 1, shows a sketch of the Unit 1 flue gas path. The figure shows the planned injection location with respective sampling locations. The reagent will be injected into the entire flue gas stream to allow the plant to continue treating all of its fly ash to maintain ESP performance. 


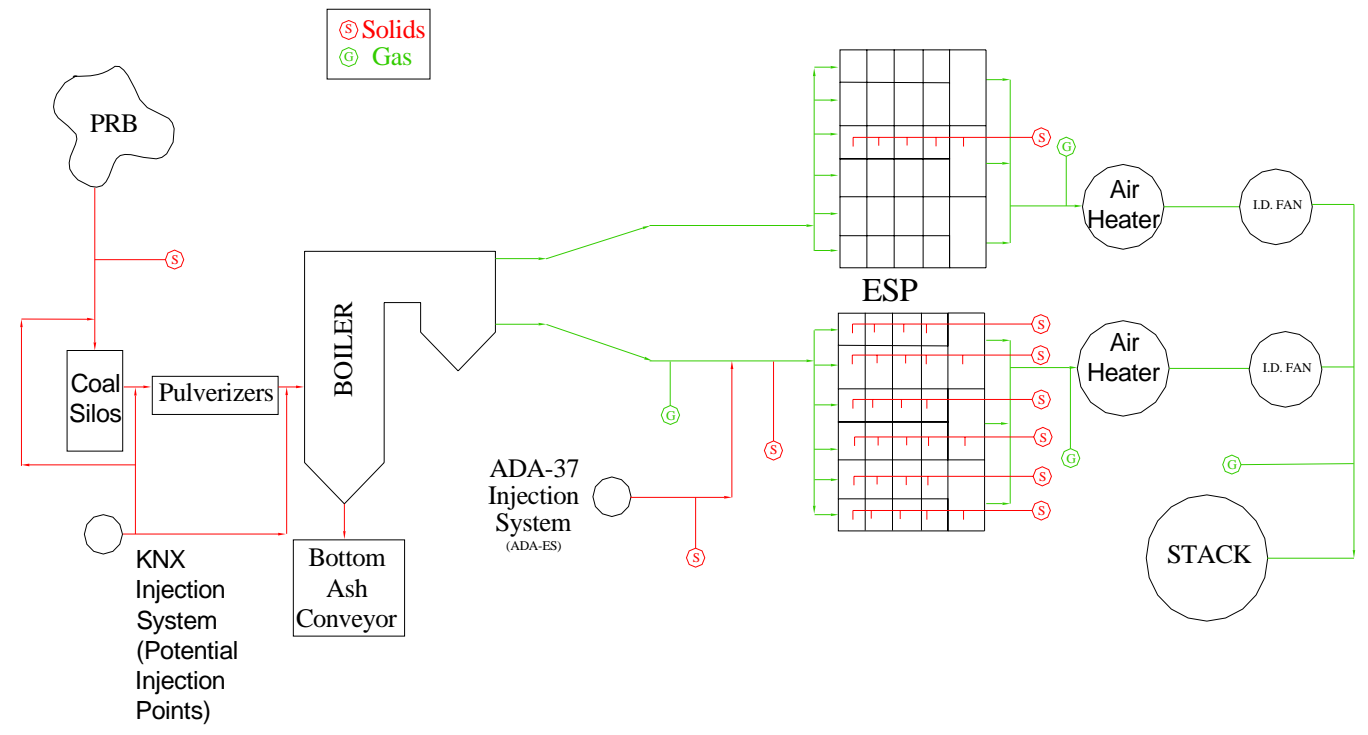

Figure 2. Sketch of Plant Process at Louisa Unit 1.

The ESP configuration for Louisa Unit 1 has four boxes in a split wedge arrangement, with each box consisting of 27 transformer/rectifier sets, 3 chambers, 51 gas passages, five electrical fields and eight bus sections. See Figure 3, ESP Electrical Field Configuration.

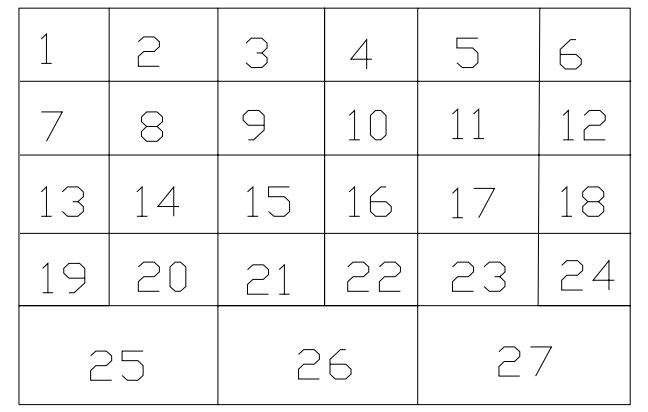

Figure 3: ESP Electrical Field Configuration. 
During the test program, liquid reagent will be injected upstream of the ESP for the full system, and mercury monitoring will occur in the main stack on $100 \%$ of the 700 MW flue gas stream. In addition, Alstom's KNX coal additive will be used during part of the test sequence to determine the benefits of halogen additives for mercury removal.

\section{General Technical Approach}

The test program activities for each test site consist of the eleven tasks shown in Table 3, Site-Specific Tasks. These tasks provide the outline for the test plan.

Table 3. Site-Specific Tasks.

\begin{tabular}{|c|l|}
\hline Task & Description \\
\hline 1. & Site Coordination, Kickoff Meeting, Test Plan, and QA/QC Plan \\
\hline 2. & Design and Install Site-Specific Equipment \\
\hline 3. & Field-Tests - Sorbent Selection \\
\hline 4. & Field-Tests - Baseline Tests \\
\hline 5. & Field-Tests - Parametric Tests \\
\hline 6. & Field-Tests - Long-Term Tests \\
\hline 7. & Data Analysis \\
\hline 8. & Sample Evaluation \\
\hline 9. & Site Report \\
\hline 10. & Technology Transfer \\
\hline 11. & Management and Reporting \\
\hline
\end{tabular}

Following are the task descriptions for the MidAmerican Louisa testing:

Task 1. Site Coordination, Kickoff Meeting, Test Plan, and QA/QC Plan

Efforts within this task include planning the site-specific tests with MidAmerican, the Louisa Generating Station, DOE/NETL, and the contributing team members. ADAES will meet with MidAmerican and Louisa plant personnel to discuss the overall scope of the program, the potential impact on plant equipment and operation, and identify potential equipment and port locations. ADA-ES will conduct additional communications with MidAmerican to discuss the host site agreements and team member cost-sharing arrangements. ADA-ES and MidAmerican will finalize these efforts during this task. Other efforts include identifying any permit requirements, developing a quality assurance/quality control plan, developing a site specific installation document, finalizing the site-specific scope for each of the team members, and putting subcontracts in place for manual (Particulate, Halogen, etc.) sampling services.

\section{Test Plan}

This document is the Test Plan for the project testing at MidAmerican's Louisa Generating Station. 


\section{QA/QC Plan}

ADA-ES personnel and subcontractors will be performing the various sampling and analytical functions required to evaluate the effectiveness of the mercury controls. All testing personnel will be required to adhere to written QA/QC procedures. QA/QC procedures will be prepared as part of separate detailed QA/QC plan that will be submitted for approvals prior to the testing dates by MidAmerican/Louisa and DOE. The plans will include the necessary QA/QC activities that are required to assure the validity of collected data. At a minimum, the QA/QC Plan will include a description of the test methods to be used: instrument/equipment testing; maintenance and inspection procedures; instrument calibration and frequency; inspection/acceptance requirements for supplies and consumables; procedures for checking data reduction and validation; and sample handling and chain of custody requirements. Standard methodologies and procedures have been established for all the methods to be used in the testing, therefore any new or unproven techniques will be noted as such when presenting information to the project.

\section{Initial Sorbent/Reagent Selection}

A key component of the test planning process for these evaluations is identifying potential sorbents/reagents for testing. The test program originally anticipated the full-scale evaluation of two different reagents. Potential alternate reagents included those that may achieve higher mercury removal or reagents that are equally as effective but lower cost. The program decided that the testing would include using the present flue-gas conditioning reagent (ADA-37), injecting it at various injection rates and under various operating conditions. Following the ADA-37 tests, the program will introduced the KNX reagent onto the coal delivery system to evaluate the effect of halogen additives used in conjunction with the flue-gas conditioning reagent.

\section{Task 2. Design and Install Site-Specific Equipment}

Site-specific equipment includes the existing flue gas conditioning distribution header and injection grid installed in the ESP inlet ducts. These are in place as part of an operational flue gas conditioning system. The Alstom KNX delivery equipment is easily portable and scalable and will be delivered during the testing phase at Louisa.

Table 4, Scope of Work for Reagent Injection System, presents a representative split of responsibilities on key equipment and activities between ADA-ES and the host plant. 
Test Plan

Table 4. Scopes of Work for Reagent System.

\begin{tabular}{|l|l|}
\hline ADA-ES & Host Site* \\
\hline Hg SCEMs, including installation & Access platforms, if necessary \\
\hline Office Trailer & Installation labor, if necessary \\
\hline $\begin{array}{l}\text { Coordination of Reagent Ordering and } \\
\text { Delivery }\end{array}$ & Compressed air \\
\hline $\begin{array}{l}\text { Coordination of Sub-Contractor Duties and } \\
\text { Activities }\end{array}$ & Electrical power \\
\hline & Signal Wiring / Telephones / Power \\
\hline & Collection of Coal and Ash Samples \\
\hline & PI System Information Trend Database \\
\hline & PI Data Collection \\
\hline & EMO Testing Unit Load Coordination \\
\hline & $\begin{array}{l}\text { Coordinate Test Program Technical Needs } \\
\text { from MidAmerican }\end{array}$ \\
\hline
\end{tabular}

* MidAmerican will be reimbursed per DOE/Host Site Agreements for expenses to facilitate the testing.

ADA-ES will oversee installation and system checkout of the overall reagent injection system equipment and mercury measurement equipment and will be responsible for general maintenance of the systems during testing. At least one ADA-ES engineer or technician who is solely dedicated to the operation of the equipment will be on-site or on-call for all tests. The actual equipment installation, not including preparation tasks, is estimated to take one week. This includes time for checkout and troubleshooting. ADA-ES personnel and/or sub-contractors will operate all testing/reagent equipment for the testing. While the host site is invited to monitor the operation of the equipment, the presence (or lack thereof) of this monitor will not delay the testing sequence unless it is a matter concerning plant reliability or safety, in which case the test crew will defer to the direction of the plant personnel.

MidAmerican Energy Company will be responsible for all permitting and any regulatory variance requirements. ADA-ES can assist by providing information to, or meeting with, regulatory agencies as required.

The site-specific equipment for this test includes the following:

\section{Reagent Injection System}

The existing reagent injection system (Figure 4, Flue Gas Conditioning System Injection Skid and Feeder System Installed at MidAmerican's Louisa Generating Station) consists of a bulk-storage vessel and a single feeder/metering train. 

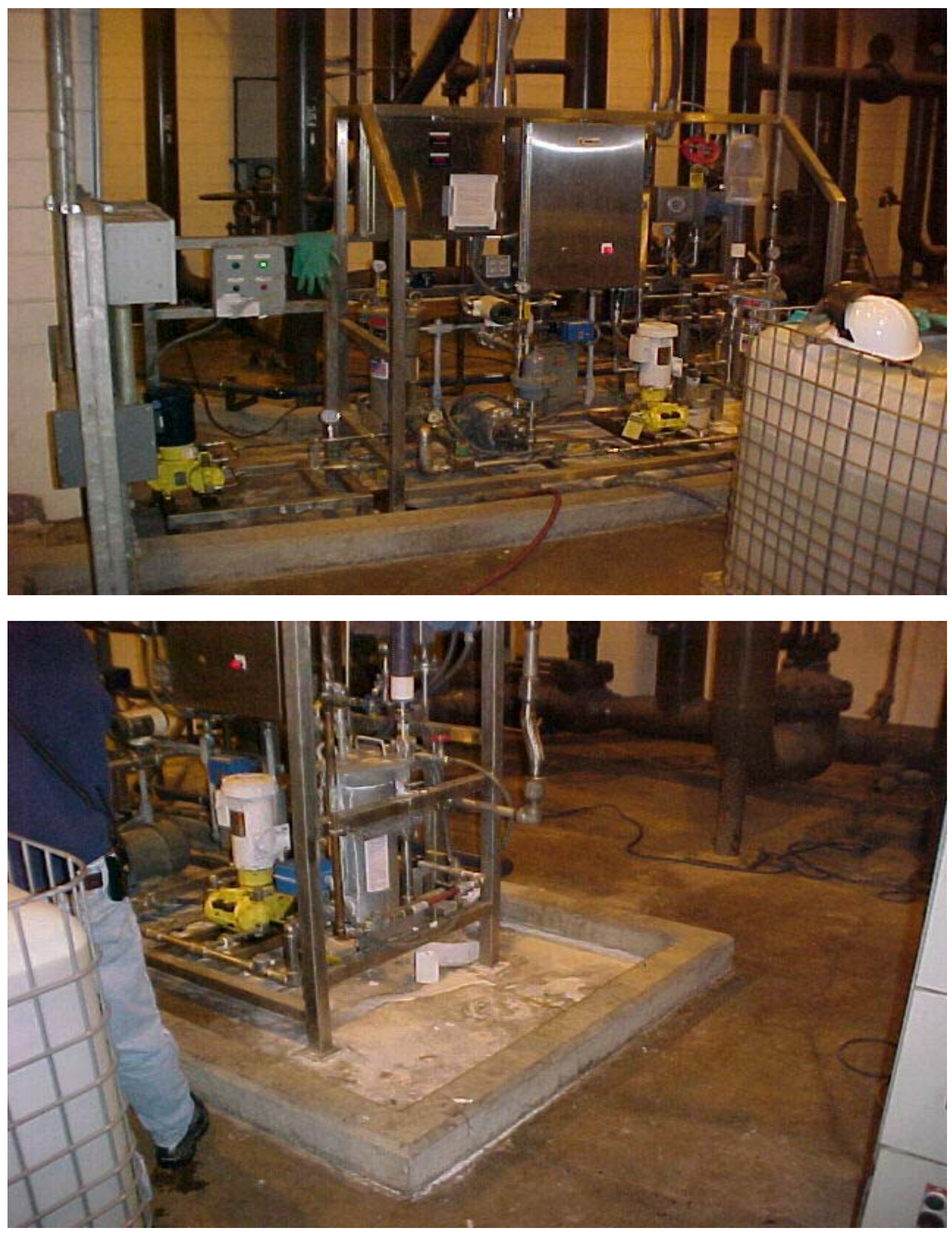

Figure 4: Flue Gas Conditioning System Injection Skid and Feeder System Installed at MidAmerican's Louisa Generating Station. 
Bulk delivery trucks deliver and unload the ADA-37 flue gas conditioning reagent into the storage vessel. The reagent feeds from the bottom of the storage vessel through a metering system and then into the feed system.

The reagent injection system for this testing has one delivery train. The train includes a pump with a meter, which measures the chemical reagent and injects the reagent into the dilution water, which is then transported to the injection point. To prevent condensation, atomizing air is used to create the maximum efficiency droplet size for distribution.

Louisa Unit 1 has two sets of injection grids, one for each ESP path. Each grid consists of six injection lances connected by a common header located upstream of the ESPs. A PLC system controls the system operation. The sorbent injection system allows controlling the reagent feed rate either manually through an $\mathrm{HMI}$ interface, or automatically through a load following signal from the plant such as unit MW load or flue gas flow rate.

The Alstom KNX liquid delivery system consists of a 55-gal drum with a feed line to a positive displacement pump capable of delivery $5 \mathrm{gph}$. The system delivers the KNX reagent to the coal via flex tubing. The point of application to the coal can be anywhere that ensures good mixing within the furnace. Typical delivery points include the main coal feeder conveyor belt and the lowest burner feed mill. The injection pump has the capability to manually vary the injection rate.

\section{Mercury Monitoring System}

The test program will use at least two mercury monitoring systems to provide realtime feedback of the mercury levels in the flue gas during baseline and reagent injection testing. Each monitoring system consists of a sample extraction and conditioning system and the analyzer system, connected with a heated sample transport umbilical bundle. The ADA-ES analyzers consist of a cold vapor atomic absorption spectrometer (CVAAS) coupled with a gold amalgamation system (AuCVAAS). Figure 5, Sketch of Mercury Measurement System, shows a sketch of the system. 


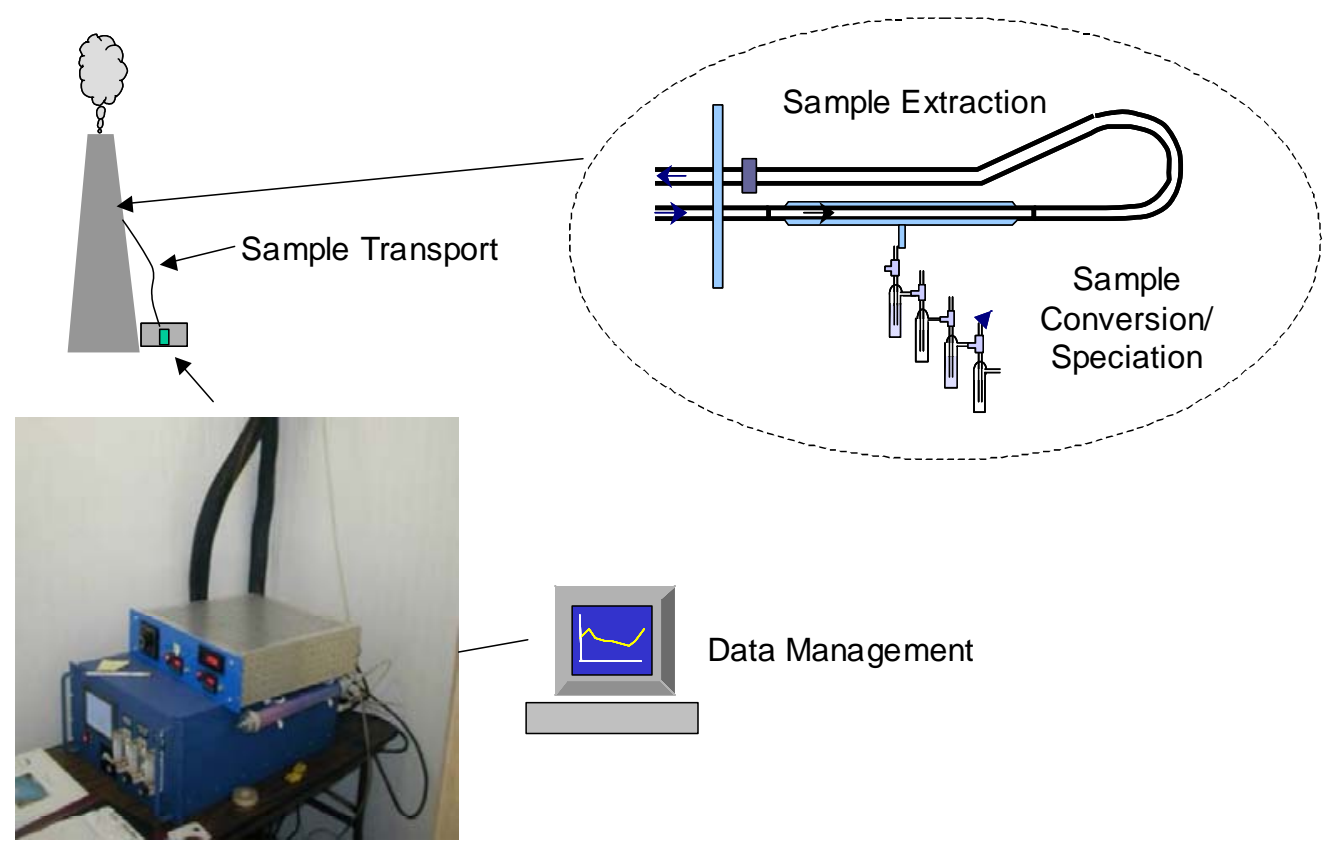

Figure 5: Sketch of Mercury Measurement System.

The figure shows an inertial separation probe. This probe separates the particulate matter from the sample with minimal sampling artifacts from fly ash or injected sorbent.

The system uses vapor-phase elemental mercury for analyzer calibration.

The monitoring system measures both total vapor-phase mercury and elemental vapor-phase mercury. The system determines total vapor-phase mercury concentrations by chemically reducing all of the oxidized mercury to the elemental form near the extraction location. To measure elemental mercury, the system removes the oxidized mercury from the sample gas while allowing elemental mercury to pass through without alteration. The oxidized mercury is then the difference between the total mercury measurement and the elemental mercury measurement.

As an alternate to the system described above, ADA-ES will use its best efforts to use Thermo's newly released I-series mercury monitoring systems for this test, dependent upon availability.

\section{Task 3. Field-Tests - Sorbent Selection}

The test program will test, at a minimum, the present flue gas conditioning reagent (ADA-37), injecting it at various injection rates and under various operating conditions. In addition, the test program will test Alstom KNX reagent as a halogen additive, adding it to the coal delivery system (TBD) prior to the coal entering the burners. 
Test Plan

\section{Task 4, 5, and 6.}

Tasks 4,5 , and 6 are the actual field testing efforts to collect data to quantify the mercury removal. Table 5, Full-Scale Test Sequence, below, outlines the testing sequence plan.

\section{Table 5. Full-Scale Test Sequence.}

\begin{tabular}{|l|l|l|l|}
\hline $\begin{array}{l}\text { Test } \\
\text { Description }\end{array}$ & Test Week & Parameters/Comments & Boiler Load \\
\hline Set Up & & $\begin{array}{l}\text { Install Monitoring Equipment } \\
\text { Inspect and Clean all Reagent Injectors }\end{array}$ & $\begin{array}{l}\text { No Load } \\
\text { Restrictions }\end{array}$ \\
\hline Baseline & Week 0 & Day 6 and 7 - No ADA-37 Injection (if possible) & $\begin{array}{l}\text { No Load } \\
\text { Restrictions }\end{array}$ \\
\hline $\begin{array}{l}\text { Parametric } \\
\text { Testing }\end{array}$ & Week 1 & $\begin{array}{l}\text { Day 1 - ADA-37, NIR (Normal Injecting Rate) } \\
\text { Day 2 - ADA-37, NIR, test crew set-up for M26A } \\
\text { Day 3 - ADA-37, NIR, M26A } \\
\text { Sorbent Screening }\end{array}$ & $\begin{array}{l}\text { Full Load } \\
\text { 6AM-6PM }\end{array}$ \\
\hline $\begin{array}{l}\text { Parametric } \\
\text { Testing }\end{array}$ & Week 1 & $\begin{array}{l}\text { Day 4 - ADA-37 Reduced Injection Rate (RIR) } \\
\text { Day 5 - ADA-37, RIR } \\
\text { Day 6 - ADA-37, RIR } \\
\text { Day 7 - ADA-37, Increased Injection Rate (IIR) }\end{array}$ & $\begin{array}{l}\text { Full Load } \\
\text { 6AM-6PM, } \\
\text { Sat - } \\
\text { Sunday: } \\
\text { Low Load }\end{array}$ \\
\hline $\begin{array}{l}\text { Parametric } \\
\text { Testing }\end{array}$ & Week 2 & $\begin{array}{l}\text { Day 1 - ADA-37, IIR } \\
\text { Day 2 - ADA-37, IIR } \\
\text { Day 3 - Transition to Alstom KNX, ADA-37 - NIR } \\
\text { Day 4 - KNX, ADA-37 - NIR } \\
\text { Day 5 - KNX, ADA-37 - NIR, M26A } \\
\text { Day 6 - KNX, ADA-37 - NIR } \\
\text { Day 7 - Transition to ADA-37, NIR }\end{array}$ & $\begin{array}{l}\text { Full Load } \\
\text { 6AM-6PM, } \\
\text { Sat - } \\
\text { Sunday: } \\
\text { Low Load }\end{array}$ \\
\hline Bay 1 and 2 - No ADA-37 Injection (if possible) & $\begin{array}{l}\text { Full Load } \\
\text { 6AM-6PM }\end{array}$ \\
\hline $\begin{array}{l}\text { Decommission } \\
\text { Daye }\end{array}$ & Week 3 & $\begin{array}{l}\text { Remove all monitoring equipment } \\
\text { Inspect and Clean all Reagent Injectors }\end{array}$ & $\begin{array}{l}\text { No Load } \\
\text { Restrictions }\end{array}$ \\
\hline
\end{tabular}

Notes: Monitor $\mathrm{Hg}$ and ESP performance during all tests.

Minimum Normal Injection Rate defined at 12 gallons per hour.

Certain tests may be cancelled or modified if opacity levels approach $20 \%$ limit.

Table 6, Test Matrix for Baseline and Parametric Test Series, details the testing during each day. See the description of project Tasks 4, 5, and 6 below for further detail of the scope of each of these tasks. 
Table 6: Test Matrix for Baseline and Parametric Test Series

\begin{tabular}{|c|c|c|c|c|c|c|c|c|c|c|c|c|c|c|}
\hline & 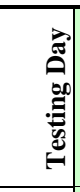 & 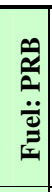 & 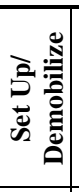 & 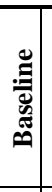 & & 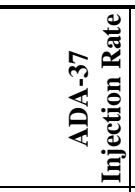 & 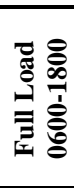 & 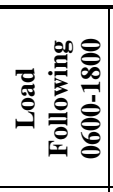 & 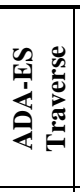 & $\sum_{\substack{\mid \\
\text { U. }}}$ & 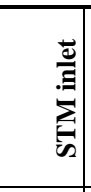 & 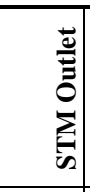 & 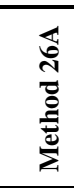 & 泀 \\
\hline & & $\mathbf{x}$ & $\mathbf{x}$ & & & & & & & & & & & \\
\hline & & $\mathbf{X}$ & $\mathbf{x}$ & & & & & & & & & & & \\
\hline & & $\mathbf{x}$ & $\mathbf{x}$ & & & & & & $\mathbf{x}$ & & 1 & 1 & & \\
\hline & & $\mathbf{X}$ & $\mathbf{x}$ & & & & & & $\mathbf{x}$ & & & & & \\
\hline SA & & $\mathbf{X}$ & & $\mathbf{x}$ & & None & & & & $\mathbf{x}$ & & & & \\
\hline SU & & $\mathbf{X}$ & & $\mathbf{x}$ & & None & & & & $\mathbf{x}$ & & & & \\
\hline $\mathrm{M}$ & 1 & $\mathbf{X}$ & & & $\mathbf{x}$ & NIR & $\mathbf{x}$ & & $\mathbf{x}$ & $\mathbf{x}$ & & & & $\mathbf{x}$ \\
\hline $\mathrm{TU}$ & 2 & $\mathbf{X}$ & & & $\mathbf{x}$ & NIR & $\mathbf{x}$ & & & $\mathbf{x}$ & 2 & 2 & $\mathbf{x}$ & $\mathbf{x}$ \\
\hline $\mathrm{W}$ & 3 & $\mathbf{x}$ & & & $\mathbf{x}$ & NIR & $\mathbf{x}$ & & & $\mathbf{x}$ & & & $\mathbf{x}$ & $\mathbf{x}$ \\
\hline $\mathrm{TH}$ & 4 & $\mathbf{X}$ & & & $\mathbf{x}$ & RIR & $\mathbf{x}$ & & & $\mathbf{x}$ & 1 & 1 & & \\
\hline $\mathrm{F}$ & 5 & $\mathbf{X}$ & & & $\mathbf{x}$ & RIR & $\mathbf{x}$ & & & $\mathbf{x}$ & 1 & 1 & & \\
\hline SA & 6 & $\mathbf{X}$ & & & $\mathbf{x}$ & RIR & & $\mathbf{x}$ & & $\mathbf{x}$ & & & & \\
\hline SU & 7 & $\mathbf{x}$ & & & $\mathbf{x}$ & IIR & & $\mathbf{x}$ & & $\mathbf{x}$ & & & & \\
\hline $\mathrm{M}$ & 8 & $\mathbf{X}$ & & & $\mathbf{x}$ & IIR & $\mathbf{x}$ & & & $\mathbf{x}$ & 1 & 1 & & \\
\hline $\mathrm{TU}$ & 9 & $\mathbf{X}$ & & & $\mathbf{x}$ & IIR & $\mathbf{x}$ & & & $\mathbf{x}$ & 1 & 1 & & \\
\hline $\mathrm{W}$ & 10 & $\mathbf{x}$ & & & $\mathbf{x}$ & $=$ & $\mathbf{x}$ & & & $\mathbf{x}$ & & & & \\
\hline $\mathrm{TH}$ & 11 & $\mathbf{x}$ & & & $\mathbf{x}$ & KNX/NIR & $\mathbf{x}$ & & & $\mathbf{x}$ & 2 & 2 & & \\
\hline $\mathrm{F}$ & 12 & $\mathbf{x}$ & & & $\mathbf{x}$ & KNX/NIR & $\mathbf{x}$ & & & $\mathbf{x}$ & 1 & 1 & $\mathbf{x}$ & \\
\hline SA & 13 & $\mathbf{X}$ & & & $\mathbf{x}$ & KNX/NIR & & $\mathbf{x}$ & & $\mathbf{x}$ & & & & \\
\hline SU & 14 & $\mathrm{X}$ & & & $\mathbf{x}$ & NIR & & & & $\mathbf{x}$ & & & & \\
\hline $\mathrm{M}$ & 15 & $\mathbf{X}$ & & $\mathbf{x}$ & & None & & & & $\mathbf{x}$ & & & & \\
\hline $\mathrm{TU}$ & 16 & $\mathbf{X}$ & & $\mathbf{x}$ & & None & & & & $\mathbf{x}$ & & & & \\
\hline $\mathrm{W}$ & 17 & $\mathbf{X}$ & $\mathbf{x}$ & & & & & & & & & & & \\
\hline \multirow[t]{3}{*}{$\mathrm{TH}$} & 18 & $\mathbf{X}$ & $\mathbf{x}$ & & & & & & & & & & & \\
\hline & & $\mathbf{x}$ & & & & & & & & & & & & \\
\hline & & & & & & & & & & & 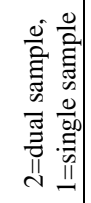 & 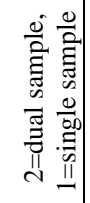 & & \\
\hline
\end{tabular}

\section{Task 4. Field-Tests - Baseline Tests}

The test program desires to conduct up to four days of baseline testing, two days prior to and two days after the parametric testing, as shown in Table 5 and Table 6. During this baseline testing, the test program will evaluate the native mercury removal with no flue gas conditioning reagent injection. These tests must necessarily depend on being able to run the unit without increasing the likelihood of 
incurring an opacity increase. The test program will coordinate very closely with the plant operations during these anticipated tests.

The first part of baseline testing will commence shortly after installation of the mercury monitors and testing equipment and the second part will take place after the parametric test sequence. During the baseline testing, the test program will perform mercury measurements upstream of the reagent injection location and at the main stack and will use this data to characterize native mercury capture as well as mercury speciation across the ESP at the aforementioned test conditions. The Unit will operate at conditions expected during the parametric tests. This includes operating the boiler at full-load and load- following conditions and operating the ESP equipment under standard operating parameters.

\section{Task 5. Field-Tests - Parametric Tests}

The test program will conduct two weeks of parametric testing, as shown in Table 5 and Table 6. During the two weeks of parametric testing, the test program will evaluate the performance of the reagent(s) at several injection concentrations.

The goal of the parametric test sequence is to develop a relationship between reagent injection concentration and mercury removal efficiencies across the ESP. The test program will develop a correlation between reagent injection concentration and ESP operation (power, spark rate, etc., and particulate emissions from the ESP) during this task.

The test program will conduct the parametric tests at plant full-load operating conditions and at plant load following conditions. The test program will perform mercury measurements with the mercury monitors.

During this Task, the test program will perform a M26A ( $\mathrm{HCl}$ and $\mathrm{HF})$ test in conjunction with performing continuous mercury measurements using the mercury monitors and dry sorbent trap method (STM). The use of Ontario Hydro and Abbreviated Method 5 (17) measurements are being evaluated in the context of funding. If funding is available, the test program will perform these measurements as well.

The test program will also perform an M26A measurement during the KNX injection sequence to compare the halogens in the flue gas during normal ADA-37 injection and when adding the halogenated reagents.

\section{Sorbent Screening}

The test program will include sorbent screening to evaluate the effectiveness of various solid reagents in removing mercury at the Louisa station. This testing will be in addition to the parametric tests and are a precursor to testing solid high temperature reagents at Council Bluffs Unit No 2, a site designated for testing later in this DOE program. 
Upon completion of the parametric testing, the test team (MidAmerican, ADA-ES, $\mathrm{DOE}, \mathrm{EPRI}$ ) will review the parametric testing results to determine if any follow on testing is necessary.

\section{Task 6. Field-Tests - Long-Term Tests}

This test program is not currently scheduled to include long term testing.

\section{Task 7. Data Analysis}

The goal of the data collection and analysis for this program is to measure the effect of reagent injection on mercury control and speciation, and the impact on the existing ESP. The test program will characterize mercury levels and plant operation.

\section{Task 8. Sample Evaluation}

The test program will collect coal and combustion byproduct samples throughout the testing period. The program will analyze selected samples to better characterize mercury removal performance and factors that may influence this performance. Coal analyses will include ultimate and proximate analyses, as well as mercury and chlorine content. The ash analysis will include mercury and other possible tests such as alkalinity, size distribution, chlorine, fluorine, and metals such as selenium and arsenic.

Ash testing will also include standard leaching test methods such as the Toxicity Characteristic Leaching Procedure (TCLP, SW846-1311) and synthetic groundwater leaching procedure (SGLP). Further analysis can be performed per specific request of the team participants.

It is important to continue evaluating these byproducts for each condition using wellestablished and documented techniques, and new techniques designed to perform even more robust analyses of the byproducts.

DOE has a test program planned to evaluate the stability of mercury on coal combustion byproducts. The Louisa test program will provide ash samples to the DOE contractor for analysis. The program will also collect and archive additional ash for other tests, including EPA, DOE, and EPRI requested tests, and independent DOE and MidAmerican approved companies.

The test program requires a sample and data management process for tracking a large quantity of samples from various process streams during the testing efforts. ADA-ES has developed a Sample and Data Management System (SDMS) that will store test data from the evaluation. The SDMS data can generate reports, track sample history, and input results from laboratory analyses. 
For data control and security, the system limits full access to the project manager and site manager at ADA-ES and the sample manager. Operators collecting samples will upload information to the database and print sample labels and Chainof-Custody forms. ADA-ES will include testing results with regularly issued reports to the test team.

\section{Task 9. Site Report}

The test program will prepare a site report documenting measurements, test procedures, analyses, and results obtained in Tasks 4,5 , and 6 . This report is a stand-alone document providing a comprehensive review of the testing. The test program will submit this report to MidAmerican. The report will also include a section on the initial economics for full-scale permanent commercial implementation of the control scheme.

Based on input from the plant, the report will address modifications to existing plant equipment and develop a work scope document for the HIGH TEMPERATURE LIQUID INJECTION process. This may include modifications to the particulate collector, ash handling system, compressed air supply, electric power capacity, other plant auxiliary equipment, utilities, and other balance of plant engineering requirements.

Finally, the test program will develop a budget level cost estimate to implement/modify the HIGH TEMPERATURE LIQUID INJECTION control technology. This will include capital cost estimates for mercury control process equipment as well as projected annual operating costs. Where possible, the report will include order-of-magnitude estimates for plant modifications and balance of plant items.

\section{Task 10. Technology Transfer}

The ultimate goal of technology transfer efforts is to make the program testing results available to the public as quickly, comprehensively and accurately as possible. To accomplish this goal, ADA-ES will work with DOE/NETL to determine and support efforts for key meetings, presentations and publications at selected conferences to increase exposure of the test results and receive comments on the applicability of the technology to the industry.

Transferring the information generated during this program to the coal-fired utility industry is an important part of the program. Dr. Durham, who has led the technology transfer activities during the DOE Phase I and II programs, will lead this important activity. Technology transfer activities in the previous testing programs included participating in DOE/NETL-sponsored meetings, EPA Hg MACT Stakeholder meetings, presentations at more than 50 events or companies, hosting a project Web site for project team members and for presentation of project information, and publication of more than 100 technical papers. 
ADA-ES will work with DOE/NETL to determine and support efforts for key meetings, presentations and publications. ADA-ES will also establish a Web site for the project and participants. ADA-ES has done this on other NETL projects with excellent results.

\section{Task 11. Management and Reporting}

This task includes the overall program management, and preparation of financial and administrative reports. This task will also include periodic meetings with DOE to discuss progress and obtain overall direction of the program from the DOE project manager. 
Test Plan

\section{Schedule}

The current schedule for activities at Louisa Generating Station is shown in Figure 6.

Figure 6: Current Schedule for the Louisa Test Program.

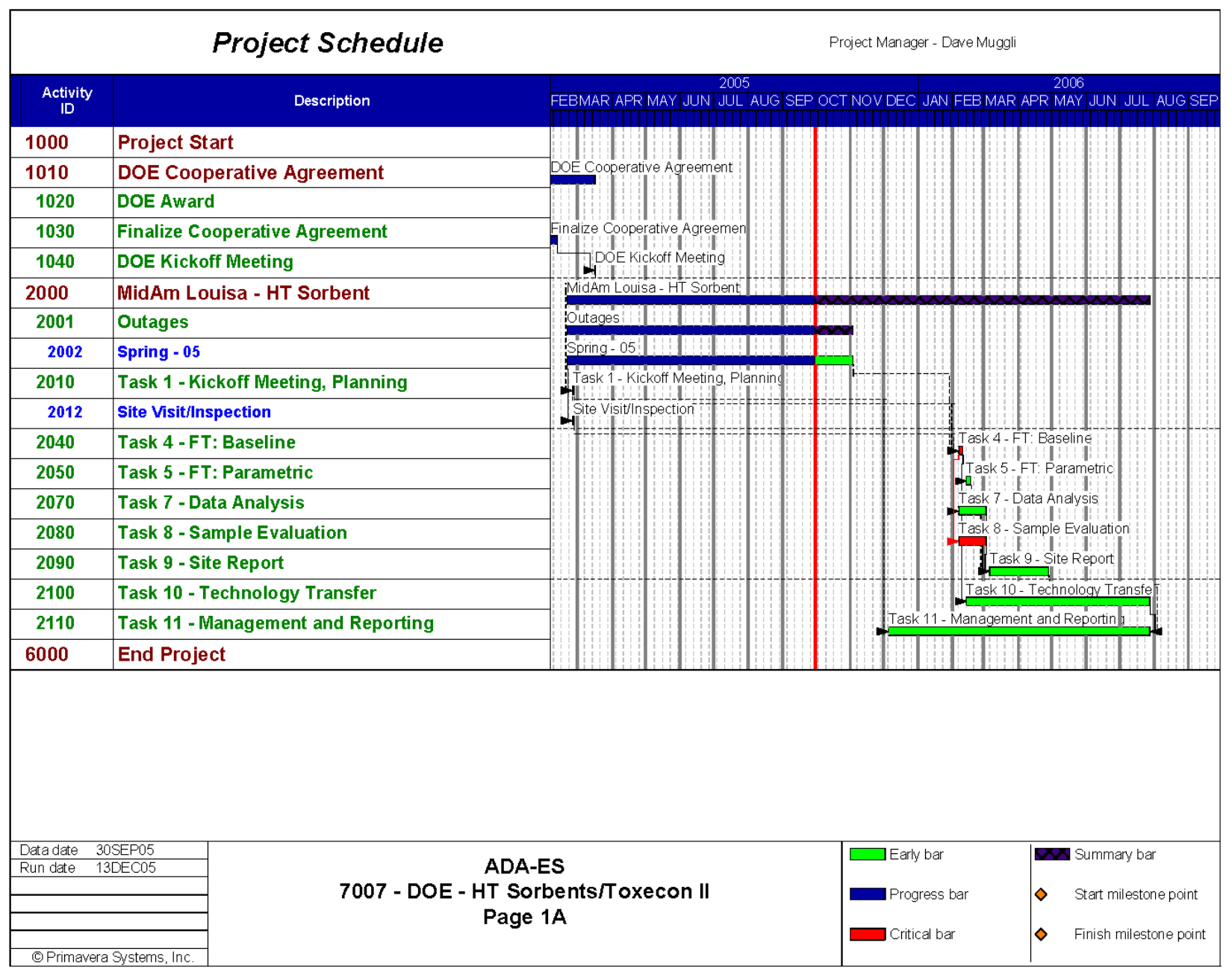


Test Plan

\section{Key Personnel}

Key personnel for the Louisa tests are identified in Table 7.

Table 7: Key Project Personnel for Louisa Mercury Field Evaluation.

\begin{tabular}{|c|c|c|c|c|}
\hline Name & Company & Role & Phone \# & E-Mail \\
\hline Andrew O’Palko & DOE/NETL & Project Manager & $304-285-4715$ & andrew.opalko@netl.doe.gov \\
\hline Kevin Dodson & MidAmerican & $\begin{array}{l}\text { MidAmerican } \\
\text { Technical Support }\end{array}$ & $563-333-8184$ & kddodson@midamerican.com \\
\hline Dave Muggli & ADA-ES & Program Manager & 303-339-8853 & davem@adaes.com \\
\hline Tom Campbell & ADA-ES & $\begin{array}{l}\text { Site Project } \\
\text { Manager }\end{array}$ & $303-339-8864$ & tomc@adaes.com \\
\hline Cody Wilson & ADA-ES & $\begin{array}{l}\text { Site Project } \\
\text { Engineer }\end{array}$ & $303-339-8860$ & codyw@adaes.com \\
\hline Ron Unser & MidAmerican & Unit Manager & $563-262-2861$ & reunser@midamerican.com \\
\hline Jerry Amrhein & ADA-ES & Hg Monitors & 303-339-8841 & jerrya@adaes.com \\
\hline Ken Baldrey & ADA-ES & Technical Expert & 303-734-1727 & kenb@adaes.com \\
\hline Jean Bustard & ADA-ES & Technical Expert & 303-734-1727 & jeanb@adaes.com \\
\hline Michael Durham & ADA-ES & Technical Expert & $303-734-1727$ & miked@adaes.com \\
\hline Cam Martin & ADA-ES & $\begin{array}{l}\text { Equipment } \\
\text { Design }\end{array}$ & $303-339-8849$ & camm@adaes.com \\
\hline Richard Schlager & ADA-ES & Contracts & $303-339-8855$ & Richards@adaes.com \\
\hline Sharon Sjostrom & ADA-ES & Technical Expert & $303-734-1727$ & sharons@adaes.com \\
\hline Connie Senior & $\begin{array}{l}\text { Reaction } \\
\text { Engineering }\end{array}$ & $\begin{array}{l}\text { Coal and } \\
\text { Byproduct Issues }\end{array}$ & $\begin{array}{l}\text { 801-364-6925 } \\
\text { ext } 37\end{array}$ & senior@reaction-eng.com \\
\hline Ramsay Chang & EPRI & Technical Expert & \begin{tabular}{|l|}
$650-855-2535$ \\
\end{tabular} & rchang@epri.com \\
\hline
\end{tabular}




\section{APPENDIX B}

Sample Collection and Management Plan 


\section{LABORATORY MERCURY FIELD EVALUATION}

Evaluation of Sorbent Injection for Mercury Control at MidAmerican Louisa Station

Sample Collection and Management Plan

Prepared by:

ADA Environmental Solutions, Inc. 8100 SouthPark Way, Unit B Littleton, CO 80120

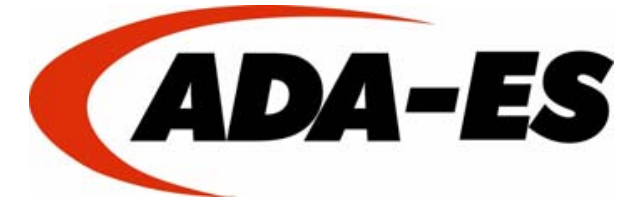

January 4, 2006 
ADA-ES, Inc. is conducting an evaluation looking at sorbent injection for mercury control at MidAmerican's Louisa Station. The overall objective of this project is to determine the cost and effects of reagent injection for control of mercury in stack emissions using a flue gas conditioning (FGC) injection configuration.

During the evaluation, fuel samples and certain process byproducts will be collected for determination of mercury content, stability, and other analytes. Process byproduct of primary interest is fly ash; however, other process byproducts may also be collected.

Sample and data management are needed for tracking approximately 100 samples from various solid process streams at Louisa Station. ADA-ES has developed a Sample and Data Management System (SDMS) that will store test data from the evaluation. These data can be used to generate reports, track sample history, and input results from laboratory analyses.

ADA-ES will also store plant operational data and other test data during the evaluation. Pertinent plant operating parameters will be logged electronically. For data control and security, full access will be limited to the project, site, and sample manager at ADA-ES as well as the MidAMerican designated representative. Operators collecting samples will be able to upload information to the database and print sample labels and Chain-of-Custody forms. ADA-ES will include results with regularly issued reports to the test team.

\section{Sampling Locations}

Samples of various gaseous and solid process streams will be collected during the evaluation. Specific flue gas samples are not included in this document. Sampling locations for Louisa Station Unit 1 are shown in Figure 1. 


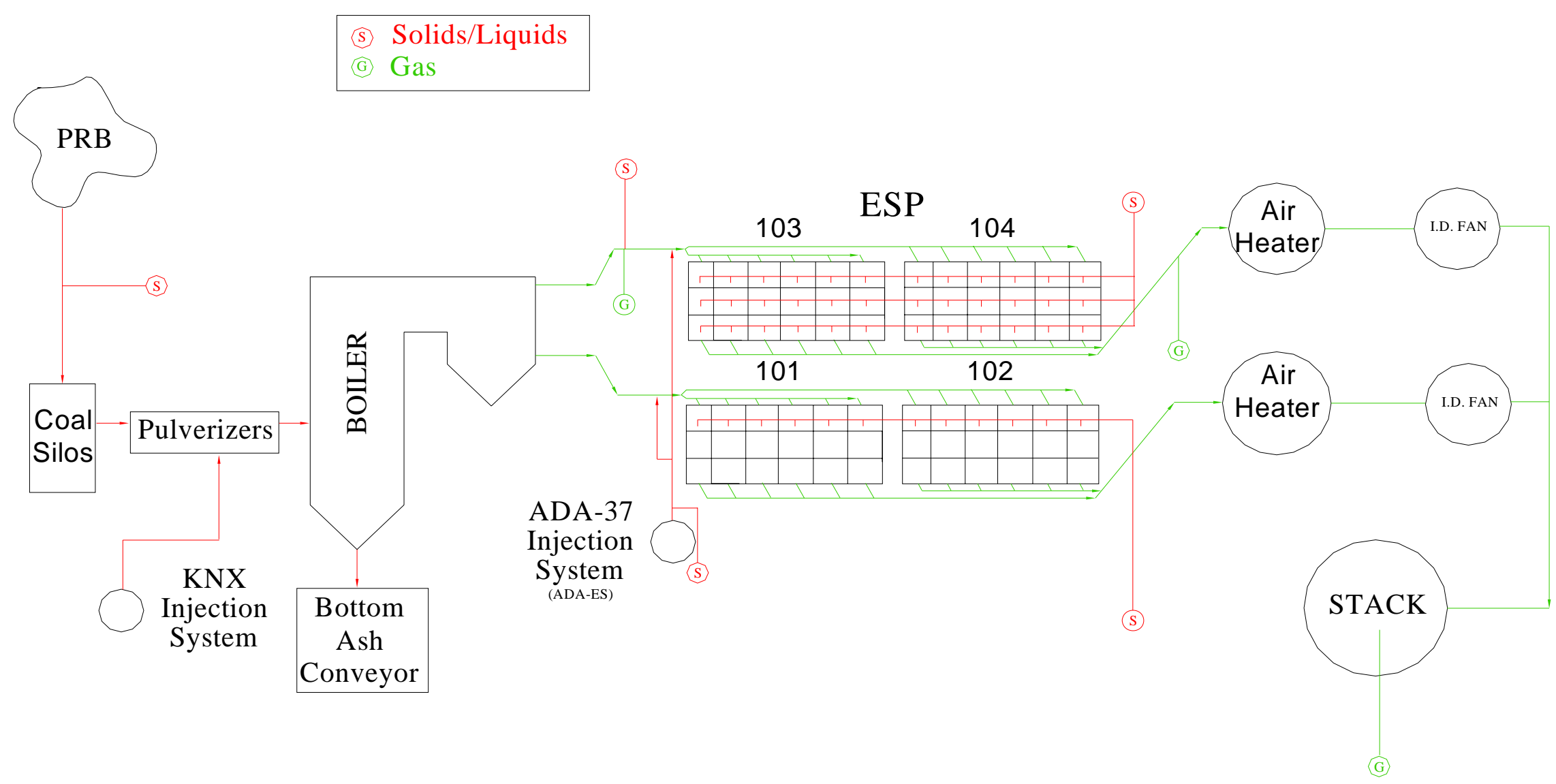

Figure 1. Louisa Station Unit 1 Configuration and Sampling Locations. 


\section{Sample Collection}

Coal and combustion byproducts will be collected during the mercury control evaluation. Samples will be segregated by the test condition (baseline and each parametric test). Collecting a representative sample is the primary objective of the sampling strategy. Representative samples will be collected only under stable and normal operating conditions unless otherwise directed by ADA-ES personnel.

\section{Sample Streams}

Coal Samples - Daily grab samples will be collected from the coal conveyor that feeds the unit 1 coal silos. Louisa plant personnel will collect the sample between 5:00 am and 11:00 am, thus representing the coal fired between 10:00am and 4:00pm. ADA-ES will provide the sample schedule and sample bottles.

ESP Fly Ash - Grab samples of ash will be collected from each row of ESP hoppers each day of testing. Samples will be segregated by the test condition (baseline and each parametric test). The samples will be stored in 1-quart sample containers for shipping to the analytical laboratories.

The schedule indicates sampling from multiple rows on both sides of the ESP. These samples will be used to determine if stratification exists throughout the system and to compare ash properties of the two sides. A sketch showing the collection fields from the ESP is shown in Figure 2. The shaded hoppers indicate the collection fields from which fly ash samples will be collected.

During testing, the rows of ESP hoppers, with the exception of the inlet row of hoppers, to be sampled should be isolated around 10:00am with ash samples being collected at 3:00 pm. This will ensure the sample collected represents the ash collected by the ESP during the test period, which typically starts at 10am and ends around 5:00pm. ADA will coordinate ash sampling and hopper emptying activities with plant operations. 


\begin{tabular}{|c|c|c|c|c|c|}
\cline { 3 - 4 } & \multicolumn{1}{c|}{ Flue Gas Flow - ESP 103 } \\
\hline 1 & 2 & 3 & 4 & 5 & 6 \\
\hline 7 & 8 & 9 & 10 & 11 & 12 \\
\hline 13 & 14 & 15 & 16 & 17 & 18 \\
\hline
\end{tabular}

\begin{tabular}{|c|c|c|c|c|c|} 
\\
\multicolumn{7}{|c|}{ Flue Gas Flow - ESP 104 } \\
\hline 1 & 2 & 3 & 4 & 5 & 6 \\
\hline 7 & 8 & 9 & 10 & 11 & 12 \\
\hline 13 & 14 & 15 & 16 & 17 & 18 \\
\hline
\end{tabular}

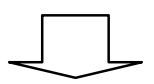

\begin{tabular}{|c|c|c|c|c|c|}
\hline \multicolumn{7}{|c|}{ Flue Gas Flow - ESP 101 } \\
\hline 1 & 2 & 3 & 4 & 5 & 6 \\
\hline 7 & 8 & 9 & 10 & 11 & 12 \\
\hline 13 & 14 & 15 & 16 & 17 & 18 \\
\hline
\end{tabular}

*Sampled Collection Fields

\begin{tabular}{|c|c|c|c|c|c|}
\hline \multicolumn{6}{|c|}{ Flue Gas Flow - ESP 102} \\
\hline 1 & 2 & 3 & 4 & 5 & 6 \\
\hline 7 & 8 & 9 & 10 & 11 & 12 \\
\hline 13 & 14 & 15 & 16 & 17 & 18 \\
\hline
\end{tabular}

Figure 2. ESP Hopper Layout and Sampling Locations.

If possible, plant personnel may collect a fly ash sample inside the ESP at the end of the testing period. This sample should be collected from any surface structures (e.g., ledges, corners) that are capable of holding fly ash material in place for a long period of time. This sample should be exposed to coal-derived flue gas for long periods of time. This sample will be analyzed for metals content (e.g., Hg, As, Se) to help determine if these toxics accumulate over time and surpass any recommended exposure limits. 
Table 1. Tentative Sampling Schedule.

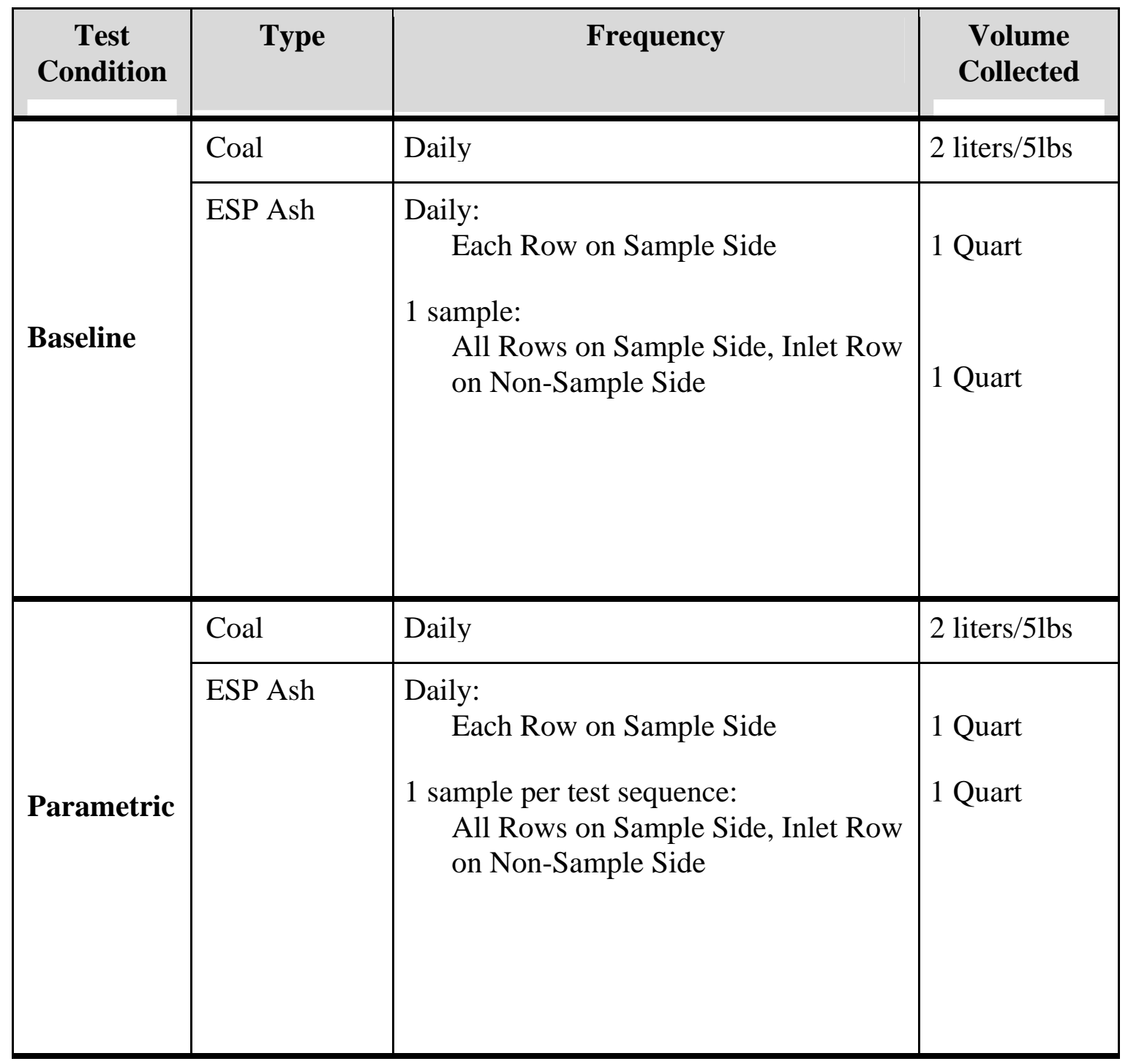




\section{Sample Management Strategy}

During the mercury control evaluation, Louisa plant personnel, as directed by ADA-ES, will collect the coal samples. ADA-ES personnel will collect the in-situ fly ash samples. The ADA-ES site manager will deliver a sampling schedule, which shows the sampling times, volume, and specific samples to collect during each testing day. A sample management flow chart is shown in Figure 3. 


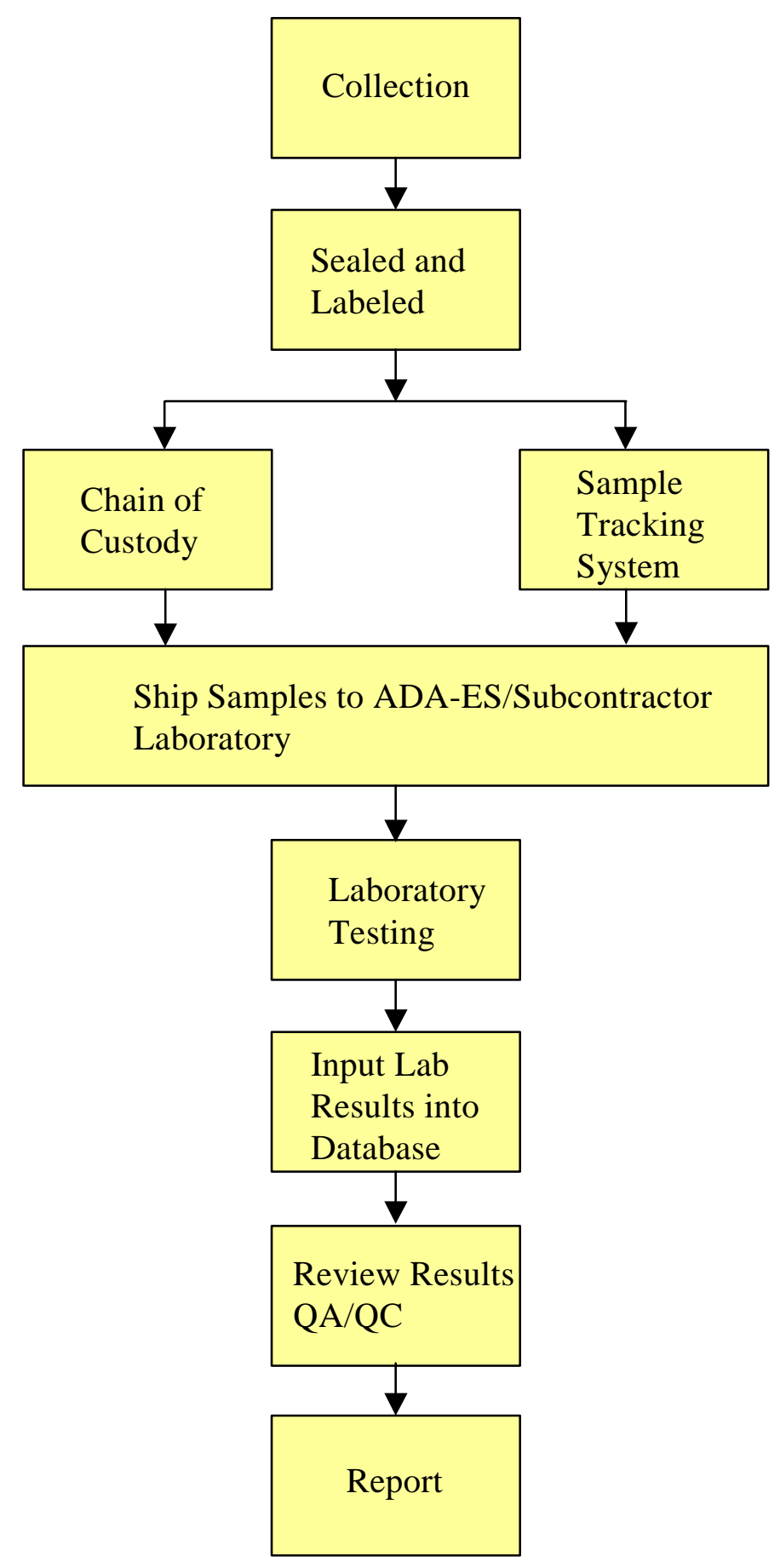

\section{Figure 3. Sample Management Flowchart.}

Once the samples have been collected, they will be delivered to ADA-ES personnel to be sealed and labeled. The samples will be logged into a database and given a sample identification number. Authorized project team members will have access to the database to see which samples have been collected and are available for testing.

Once the samples have been sealed and labeled, ADA-ES personnel will generate a Chain-of Custody (COC) form to be delivered with each shipment of samples. The COC will be used 
for sample tracking and identification. Although ADA-ES will not enforce the strict COC procedures (e.g., signatures to release sample custody, controlled access), all pertinent information will be recorded.

The samples, along with a COC, will be shipped to the ADA-ES laboratory for storage. Once received, ADA-ES will identify samples for mercury, and other, analyses. Other analyses will include ultimate and proximate analyses for coal and elemental analyses for coal and ash samples (including chlorine and fluorine contents).

\section{Sample Analysis}

Although previous tests from other programs have shown that the byproducts are extremely stable, it is important to continue evaluating these byproducts for each condition using wellestablished and documented techniques, and new techniques designed to perform even more robust analyses of the byproducts. Additional ash samples will be collected and archived for other tests, including tests requested by EPA, DOE, and independent companies approved by DOE. No samples will be shipped to outside firms without prior approval of MidAmerican and DOE.

Standard leaching test methods conducted on the fly ash samples will include the Toxicity Characteristic Leaching Procedure (TCLP, SW846-1311) and the synthetic groundwater leaching procedure (SGLP). Solid and liquid samples will be collected and analyzed according to the methods as prescribed in Table 2.

The final series of tests are optional, based on whether a determination is made that additional analyses are needed for purposes of troubleshooting or for gaining additional insight into control options. For example, it may be desirable to determine the size and composition of the ash for certain applications. These analyses will provide information on the impacts of mercury control on ash properties. The properties have a significant impact on the performance of combustion and environmental control systems. 
Table 2. Summary of Byproduct and Waste Characterization Testing

\begin{tabular}{|c|l|l|l|}
\hline Series & Test Purpose & Test Method & Comments \\
\hline 1 & Ash Disposal & TCLP (SW846-1311) & $\begin{array}{l}\text { Measures leachable Hg, As, Ba, Cd, } \\
\text { Cr, Pb, Se, Ag }\end{array}$ \\
\hline 2 & $\begin{array}{l}\text { Environmental } \\
\text { Ltability - }\end{array}$ & EERC SGLP & $\begin{array}{l}\text { Measures leachable Hg at 18 hours, } \\
\text { 2 weeks, and 4 weeks }\end{array}$ \\
\hline 3 & Special Testing & Various & $\begin{array}{l}\text { As needed for troubleshooting or site- } \\
\text { specific information needs }\end{array}$ \\
\hline
\end{tabular}

Once the laboratory testing is complete, results will be logged into the SDMS. Authorized project team members will have access to the database to view the results. A report will be generated summarizing results from the sample analyses.

\section{Flue Gas Samples}

Flue gas measurements will be made at the locations indicated on Figure 1. Flue gas analyses will include the EPA Method 26A. Hg analyzers and sorbent trap method tests (STM) will also be used at selected locations measuring near-real-time vapor-phase mercury concentrations in the flue gas. 
Table 3. Sampling and Analytical Matrix.

\begin{tabular}{|c|c|c|c|}
\hline Sampling Location & Sample/Type & Sampling Method & Analytical Method \\
\hline \multirow{3}{*}{$\begin{array}{l}\text { Economizer } \\
\text { Outlet/ESP Inlet }\end{array}$} & $\mathrm{Hg}$ - Vapor Phase & STM & EPA Method 1631 \\
\hline & $\begin{array}{l}\text { Total/Elemental Mercury - } \\
\text { Vapor Phase }\end{array}$ & Semi-Continuous & AF or AA -Analysis \\
\hline & Particulate $\mathrm{Hg}$ & Modified $\mathrm{PM}_{2.5}$ & Modified Ohio Lumix ASTM 6722D-01 \\
\hline \multirow{3}{*}{$\begin{array}{l}\text { ESP Outlet and/or } \\
\text { Stack }\end{array}$} & $\mathrm{HBr}, \mathrm{HCl}, \mathrm{HF}, \mathrm{BR}_{2}, \mathrm{CL}_{2}$ & M26A & Ion chromatography per the promulgated EPA Method 26a \\
\hline & $\mathrm{Hg}$ & STM & EPA Method 1631 \\
\hline & Total/Elemental Mercury & Continuous & AF or AA-Analysis \\
\hline \multirow[t]{6}{*}{ Coal Fuel to Boiler } & $\mathrm{Hg}$ & Grab Sample & ASTM D6414-99 or 01 \\
\hline & $\mathrm{Cl}$ & Grab Sample & Modified ASTM D5808 (Oxidative Hydrolysis Microcoulometry) \\
\hline & $\mathrm{F}$ & Grab Sample & TBD \\
\hline & Ultimate Analysis & Grab Sample & \\
\hline & Proximate Analysis & Grab Sample & \\
\hline & Trace Metals & Grab Sample & \\
\hline \multirow[t]{5}{*}{ Bottom Ash, Fly Ash } & $\mathrm{Hg}$ & Grab Sample & ASTM D6414-99 or 01 \\
\hline & $\mathrm{Cl}$ & Grab Sample & Modified ASTM D5808 (Oxidative Hydrolysis Microcoulometry) \\
\hline & LOI / Carbon Content & Grab Sample & ASTM C311-04 \\
\hline & Leaching & Grab Sample & TCLP, SW846-1311, SGLP \\
\hline & Trace Metals & Grab Sample & \\
\hline
\end{tabular}




\section{APPENDIX C \\ Gaseous Emissions Test, GE Energy}

Copyright $_{\odot} 2006$ GE Energy. This paper was written with support of the U.S. Department of Energy under Contract No. DE-FC26-05NT42307. The Government reserves for itself and others acting on its behalf a royalty-free, nonexclusive, irrevocable, worldwide license for Governmental purposes to publish, distribute, translate, duplicate, exhibit, and perform this copyrighted paper. 


\title{
GE Energy
}

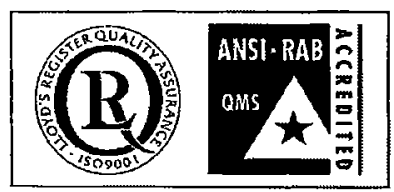

ISO 9001 Accredited

Quality System

\section{GASEOUS EMISSIONS TEST}

Performed For

ADA-ES, Inc.

\author{
At The \\ MidAmerican Energy \\ Louisa Generating Station \\ Unit 1 Stack \\ Muscatine, lowa
}

Test Dates

February 8 and 9, 2006

Report No.

GE Energy Management Services, Inc. Report M22E1180A

Report Submittal Date

March 10, 2006

GE Energy Management Services, Inc. 888 Industrial Drive

Elmhurst, Illinois 60126

USA 


\section{GE Energy}

\section{TABLE OF CONTENTS}

CERTIFICATION SHEET

1.0 INTRODUCTION

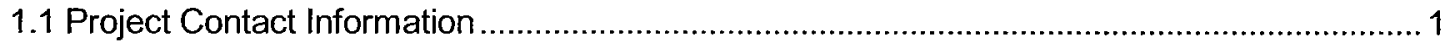

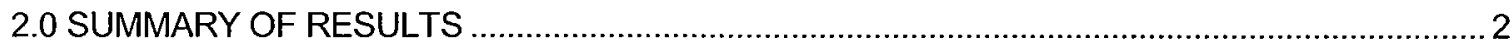

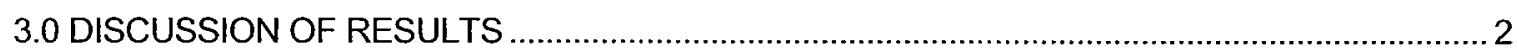

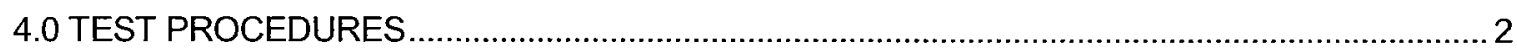

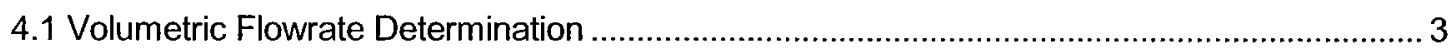

4.2 Oxygen $\left(\mathrm{O}_{2}\right)$ /Carbon Dioxide $\left(\mathrm{CO}_{2}\right)$ Determination............................................................ 3

4.3 Hydrogen Halides $(\mathrm{HCl}, \mathrm{HBr}, \mathrm{HF})$ and Halogens $\left(\mathrm{Cl}_{2}, \mathrm{Br}_{2}\right)$ Determination............................. 3

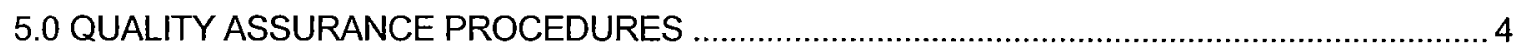

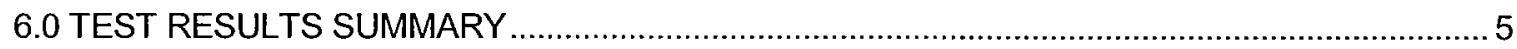

APPENDIX

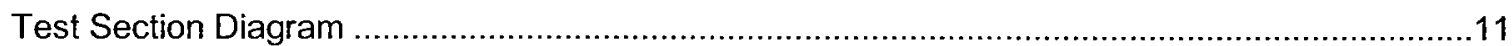

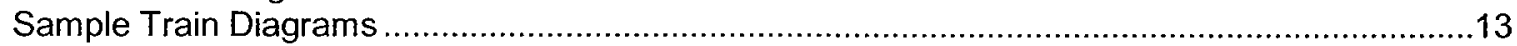

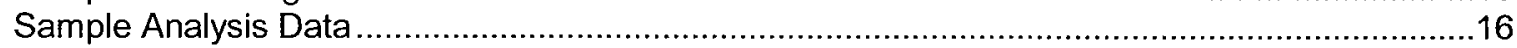

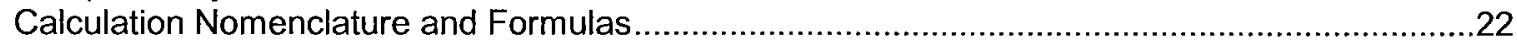

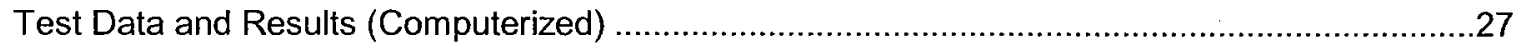

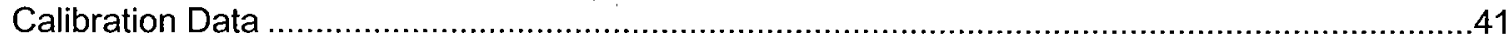

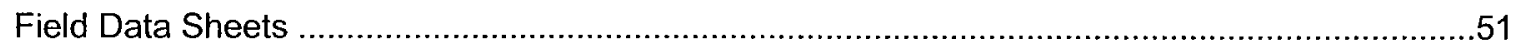




\section{GE Energy}

\section{CERTIFICATION SHEET}

Having reviewed the test program described in this report, I hereby certify the data, information, and results in this report to be accurate and true according to the methods and procedures used.

Data collected under the supervision of others is included in this report and is presumed to have been gathered in accordance with recognized standards.

GE ENERGY MANAGEMENT SERVICES, INC.

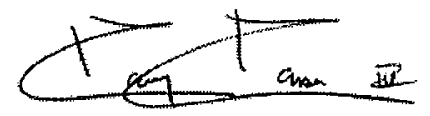

Harry Hanson

Senior Project Manager

(c) 2006, General Electric Company. All rights reserved. The contents of this document are the property of General Electric Company. No part of this work may be reproduced or transmitted in any form or by any means, except as permitted in written license agreement with General Electric Company. General Electric Company has made every reasonable attempt to ensure the completeness and accuracy of this document. The GE logo is a registered trademark of General Electric Company. 


\title{
GE Energy
}

\author{
GASEOUS EMISSIONS TEST \\ Performed For \\ ADA-ES, INC. \\ At the \\ MidAmerican Energy \\ Louisa Generating Station \\ Unit 1 Stack \\ Muscatine, lowa \\ February 8 and 9,2006
}

\subsection{INTRODUCTION}

GE Energy Management Services, Inc. ("GE Energy") performed a gaseous emission test program on the Unit 1 Stack at the Louisa Generating Station of MidAmerican Energy in Muscatine, lowa on February 8 and 9, 2006. The tests were authorized by MidAmerican Energy and performed for ADA-ES, Inc.

The purpose of this test program was to determine hydrogen chloride $(\mathrm{HCl})$, hydrogen fluoride $(\mathrm{HF})$, hydrogen bromide $(\mathrm{HBr})$, bromine $\left(\mathrm{Br}_{2}\right)$ and chlorine $\left(\mathrm{Cl}_{2}\right)$ concentrations and emission rates during normal operating conditions.

\subsection{Project Contact Information}

\begin{tabular}{|c|c|c|}
\hline Location & Address & Contact \\
\hline Test Facility & $\begin{array}{l}\text { MidAmerican Energy } \\
\text { Louisa Generating Station } \\
8602172^{\text {nd }} \text { Street } \\
\text { Muscatine, lowa } 52761\end{array}$ & $\begin{array}{l}\text { Mr. Jim Haack } \\
\text { (563) 262-2860 (phone) } \\
\text { (563) 262-2892 (fax) }\end{array}$ \\
\hline $\begin{array}{l}\text { Testing } \\
\text { Coordinator }\end{array}$ & $\begin{array}{l}\text { ADA-ES, Inc. } \\
8100 \text { SouthPark Way, Unit B } \\
\text { Littleton, Colorado } 80120\end{array}$ & $\begin{array}{l}\text { Mr. Eric Zipp } \\
\text { Field Engineer } \\
\text { (303) 734-1727 (phone) } \\
\text { (303) 734-0330 (fax) } \\
\text { ericz@adaes.com } \\
\end{array}$ \\
\hline $\begin{array}{l}\text { Testing Company } \\
\text { Representative }\end{array}$ & $\begin{array}{l}\text { GE Energy Management Services, Inc. } \\
888 \text { Industrial Drive } \\
\text { Elmhurst, Illinois } 60126\end{array}$ & $\begin{array}{l}\text { Mr. Christopher F. Miller } \\
\text { Project Supervisor } \\
630-530-6616 \text { (phone) } \\
630-530-6630 \text { (fax) } \\
\text { christopher.miller@ge.com }\end{array}$ \\
\hline
\end{tabular}

Messrs. M. Kielanowicz and C. Miller of GE Energy conducted the testing. 


\section{GE Energy}

\subsection{SUMMARY OF RESULTS}

During this test program, three (3) sixty-minute $\mathrm{HCl}, \mathrm{HF}, \mathrm{HBr}, \mathrm{Br}_{2}$ and $\mathrm{Cl}_{2}$ test runs were conducted on the Unit 1 Stack test location. The average test results were as follows:

\begin{tabular}{||c|c|c|c|}
\hline \multicolumn{2}{|c|}{ Parameter } & February 8, 2006 & February 9, 2006 \\
\hline \hline \multirow{2}{*}{$\mathrm{HCl}$} & $\mathrm{ppm}$ & 1.326 & 0.799 \\
\cline { 2 - 4 } & $\mathrm{lb} / \mathrm{hr}$ & 12.697 & 7.912 \\
\hline \multirow{3}{*}{$\mathrm{HF}$} & $\mathrm{ppm}$ & 0.312 & 0.265 \\
\cline { 2 - 4 } & $\mathrm{lb} / \mathrm{hr}$ & 1.639 & 1.440 \\
\hline \multirow{2}{*}{$\mathrm{HBr}$} & $\mathrm{ppm}$ & 0.129 & 0.380 \\
\cline { 2 - 4 } & $\mathrm{lb} / \mathrm{hr}$ & 2.733 & 8.324 \\
\hline \multirow{2}{*}{$\mathrm{Br}_{2}$} & $\mathrm{ppm}$ & 0.065 & 0.063 \\
\cline { 2 - 4 } & $\mathrm{lb} / \mathrm{hr}$ & 2.733 & 2.724 \\
\hline $\mathrm{Cl}_{2}$ & $\mathrm{ppm}$ & 0.289 & 0.163 \\
\cline { 2 - 5 } & $\mathrm{lb} / \mathrm{hr}$ & 5.376 & 3.129 \\
\hline
\end{tabular}

Complete test results summaries are tabulated and can be found in Section 6.0.

\subsection{DISCUSSION OF RESULTS}

No problems were encountered with the testing equipment during the test program. Source operation appeared normal during the entire test program. Unit operating data was recorded and retained by plant personnel.

\subsection{TEST PROCEDURES}

All testing, sampling, analytical, and calibration procedures used for this test program were performed as described in the Title 40, Code of Federal Regulations, Part 60 (40CFR60), Appendix A, Methods 1, 2, 3, 4, 26A and the latest revisions thereof. Where applicable, the Quality Assurance Handbook for Air Pollution Measurement Systems, Volume III, Stationary Source Specific Methods, United States Environmental Protection Agency (USEPA) 600/R94/038c, September 1994 was used to supplement procedures. 


\section{GE Energy}

\subsection{Volumetric Flowrate Determination}

In order to determine the emission rate on a $\mathrm{lbs} / \mathrm{hr}$ basis, the gas velocity and volumetric flowrate were determined using Method 2, 40CFR60.

Velocity pressures were determined by traversing the test location with an S-type pitot tube. Temperatures were measured using a K-type thermocouple with a calibrated digital temperature indicator. The molecular weight and moisture content of the gases were determined to permit the calculation of the volumetric flowrate. Sampling points utilized were determined using Method 1, 40CFR60.

\subsection{Oxygen $\left(\mathrm{O}_{2}\right) /$ Carbon Dioxide $\left(\mathrm{CO}_{2}\right)$ Determination}

Oxygen $\left(\mathrm{O}_{2}\right)$ and carbon dioxide $\left(\mathrm{CO}_{2}\right)$ gas contents were determined in accordance with Method 3, 40CFR60. This method collected samples in an integrated manner and analyzed the samples using a Hays Orsat gas analyzer. Several gas extractions were performed during each test run to ensure a stable reading. Mandatory leak checks were performed prior to and following each use. Chemicals are changed frequently and inspected for reactivity prior to each use.

\subsection{Hydrogen Halides $(\mathrm{HCl}, \mathrm{HBr}, \mathrm{HF})$ and Halogens $\left(\mathrm{Cl}_{2}, \mathrm{Br}_{2}\right)$ Determination} Hydrogen chloride $(\mathrm{HCl})$, hydrogen fluoride $(\mathrm{HF})$, Hydrogen bromide $(\mathrm{HBr})$, bromine $\left(\mathrm{Br}_{2}\right)$ and chlorine $\left(\mathrm{Cl}_{2}\right)$ concentrations were determined using Method 26A, 40CFR60. An integrated twenty-four-point sample was extracted from the gas stream and passed through $0.1 \mathrm{~N}$ sulfuric acid $\left(\mathrm{H}_{2} \mathrm{SO}_{4}\right)$ and $0.1 \mathrm{~N}$ sodium hydroxide $(\mathrm{NaOH})$. The samples were then analyzed by ion chromatography. The sample train consisted of a heated glass probe liner, a heated optional filter, and six impingers. The first impinger was short stemmed and empty to knock out heavy moisture, the second and third impingers contained the dilute sulfuric acid, the fourth and fifth impingers contained a $0.1 \mathrm{~N}$ sodium hydroxide $(\mathrm{NaOH})$ scrubber solution to remove any remaining chlorine, and the sixth impinger contained silica gel to absorb any remaining moisture. The train was leak checked prior to and after each run. The sample was then extracted isokinetically. The samples were recovered by quantitatively transferring the contents of the first three impingers (the knock out and the two acidic absorbing solution impingers) and deionized water rinses to a glass sample jar. Impingers 4 and 5 (alkaline absorbing solution) and deionized water rinses are transferred to a separate glass sample jar. The samples were labeled, and the level marked for transfer to the laboratory. The samples were then analyzed by ion chromatography.

The test trains were weighed before and after each test for moisture determination. 


\section{GE Energy}

The test crew performed sample recovery at the test site and initial analysis was performed on site. Samples were transported to an approved lab for final analysis. Copies of all sample analysis sheets are appended to this report.

Calculations were performed on the computer. An explanation of the nomenclature and calculations along with the complete test results are appended. Also appended are the calibration data and copies of the raw field data sheets.

Raw data are kept on file at the GE Energy office in Elmhurst, Illinois. All samples from this test program (not already used in analysis) will be retained for 60 days after the submittal of the report, after which they will be discarded unless GE Energy is advised otherwise.

\subsection{QUALITY ASSURANCE PROCEDURES}

GE Energy recognizes the previously described reference methods to be very technique oriented and attempts to minimize all factors which can increase error by implementing its Quality Assurance Program into every segment of its testing activities.

Shelf life of chemical reagents prepared at the GE Energy laboratory did not exceed those specified in the above mentioned methods; and those reagents having a shelf life of one week were prepared daily at the jobsite. When on-site analyses were required, the same person performing the analysis performed all reagent standardizations daily.

Dry test meters and wet test meters were calibrated according to methods described in the Quality Assurance Handbook, Sections 3.3.2, 3.4.2 and 3.5.2. Percent error for the wet test meter according to the methods was less than the allowable error of 1.0 percent. The dry test meters measured the test sample volumes to within 2 percent at the flowrate and conditions encountered during sampling. 


\section{GE Energy}

\subsection{TEST RESULTS SUMMARY}




\title{
GE Energy
}

GASEOUS TEST RESULTS SUMMARY

\author{
MidAmerican Energy \\ Louisa Generating Station \\ Unit 1 Stack \\ February 8, 2006
}

\begin{tabular}{|c|c|c|c|c|c|c|}
\hline \multirow[b]{2}{*}{ RUN \# } & \multirow[b]{2}{*}{ Time } & \multirow{2}{*}{$\begin{array}{c}\mathrm{CO}_{2} \\
\% \text { dry }\end{array}$} & \multirow{2}{*}{$\begin{array}{c}\mathrm{O}_{2} \\
\% \text { dry }\end{array}$} & \multirow{2}{*}{$\begin{array}{c}\text { Flow } \\
\text { dscfm }\end{array}$} & \multicolumn{2}{|c|}{$\mathrm{HCl}$} \\
\hline & & & & & ppm & lb/hr \\
\hline 1 & $11: 25-12: 25$ & 13.5 & 6.5 & $1,683,018$ & 0.705 & 6.743 \\
\hline 2 & $13: 15-14: 15$ & 13.5 & 6.5 & $1,685,823$ & 2.602 & 24.922 \\
\hline 3 & $14: 45-15: 45$ & 13.3 & 6.8 & $1,682,868$ & 0.672 & 6.428 \\
\hline \multicolumn{2}{|c|}{ Average } & 13.4 & 6.6 & $1,683,903$ & 1.326 & 12.697 \\
\hline
\end{tabular}

\begin{tabular}{|c|c|c|c|c|c|c|}
\hline \multirow{2}{*}{ RUN \# } & Time & $\begin{array}{c}\mathrm{CO}_{2} \\
\% \text { dry }\end{array}$ & $\begin{array}{c}\mathrm{O}_{2} \\
\% \text { dry }\end{array}$ & $\begin{array}{c}\text { Flow } \\
\text { dscfm }\end{array}$ & ppm & Ib/hr \\
\hline 1 & $11: 25-12: 25$ & 13.5 & 6.5 & $1,683,018$ & 0.350 & 1.834 \\
\hline 2 & $13: 15-14: 15$ & 13.5 & 6.5 & $1,685,823$ & 0.291 & 1.530 \\
\hline 3 & $14: 45-15: 45$ & 13.3 & 6.8 & $1,682,868$ & 0.296 & 1.552 \\
\hline \multicolumn{2}{|l}{ Average } & 13.4 & 6.6 & $1,683,903$ & 0.312 & 1.639 \\
\hline
\end{tabular}

\begin{tabular}{|c|c|c|c|c|c|c|}
\hline \multirow{2}{*}{ RUN \# } & Time & \multirow{2}{*}{$\begin{array}{c}\mathrm{CO}_{2} \\
\% \text { dry }\end{array}$} & \begin{tabular}{c}
\multirow{2}{*}{$\mathrm{O}_{2}$} \\
$\%$ dry
\end{tabular} & $\begin{array}{c}\text { Flow } \\
\text { dscfm }\end{array}$ & \multicolumn{2}{|c|}{$\mathrm{HBr}^{*}$} \\
\hline 1 & $11: 25-12: 25$ & 13.5 & 6.5 & $1,683,018$ & 0.127 & 2.697 \\
\hline 2 & $13: 15-14: 15$ & 13.5 & 6.5 & $1,685,823$ & 0.129 & 2.733 \\
\hline 3 & $14: 45-15: 45$ & 13.3 & 6.8 & $1,682,868$ & 0.131 & 2.771 \\
\hline \multicolumn{2}{|c|}{ Average } & 13.4 & 6.6 & $1,683,903$ & 0.129 & 2.733 \\
\hline
\end{tabular}

${ }^{*} \mathrm{HBr}$ laboratory results are below the detection limit of $0.05 \mathrm{mg}$.

Note: $\quad$ Test 1 flow value is the average flow runs pre 1.and post 1 .

Test 2 flow value is the average flow runs post 1 and post 2 .

Test 3 flow value is the average flow runs post 2 and post 3 . 


\section{GE Energy}

\section{GASEOUS TEST RESULTS SUMMARY}

MidAmerican Energy

Louisa Generating Station

Unit 1 Stack

February 8, 2006

\begin{tabular}{|c|c|c|c|c|c|c||}
\hline \multirow{2}{*}{ RUN \# } & Time & \multirow{2}{*}{$\begin{array}{c}\mathrm{CO}_{2} \\
\% \text { dry }\end{array}$} & $\begin{array}{c}\mathrm{O}_{2} \\
\% \text { dry }\end{array}$ & $\begin{array}{c}\text { Flow } \\
\text { dscfm }\end{array}$ & \multicolumn{2}{|c|}{$\mathrm{Br}_{2}{ }^{*}$} \\
\hline 1 & $11: 25-12: 25$ & 13.5 & 6.5 & $1,683,018$ & 0.064 & 2.697 \\
\hline 2 & $13: 15-14: 15$ & 13.5 & 6.5 & $1,685,823$ & 0.065 & 2.733 \\
\hline 3 & $14: 45-15: 45$ & 13.3 & 6.8 & $1,682,868$ & 0.066 & 2.771 \\
\hline \multicolumn{2}{|c}{ Average } & 13.4 & 6.6 & $1,683,903$ & 0.065 & 2.733 \\
\hline
\end{tabular}

${ }^{*} \mathrm{Br}_{2}$ laboratory results are below the detection limit of $0.05 \mathrm{mg}$.

\begin{tabular}{|c|c|c|c|c|c|c|}
\hline \multirow[b]{2}{*}{ RUN \# } & \multirow[b]{2}{*}{ Time } & \multirow{2}{*}{$\begin{array}{c}\mathrm{CO}_{2} \\
\% \text { dry }\end{array}$} & \multirow{2}{*}{$\begin{array}{c}\mathrm{O}_{2} \\
\% \text { dry }\end{array}$} & \multirow{2}{*}{$\begin{array}{l}\text { Flow } \\
\text { dscfm }\end{array}$} & \multicolumn{2}{|c|}{$\mathrm{Cl}_{2}$} \\
\hline & & & & & ppm & Ib/hr \\
\hline 1 & $11: 25-12: 25$ & 13.5 & 6.5 & $1,683,018$ & 0.339 & 6.311 \\
\hline 2 & $13: 15-14: 15$ & 13.5 & 6.5 & $1,685,823$ & 0.390 & 7.269 \\
\hline 3 & $14: 45-15: 45$ & 13.3 & 6.8 & $1,682,868$ & 0.137 & 2.549 \\
\hline & rage & 13.4 & 6.6 & $1,683,903$ & 0.289 & 5.376 \\
\hline
\end{tabular}

Note: $\quad$ Test 1 flow value is the average flow runs pre 1 .and post 1 .

Test 2 flow value is the average flow runs post 1 and post 2 .

Test 3 flow value is the average flow runs post 2 and post 3 . 


\section{GE Energy}

\section{GASEOUS TEST RESULTS SUMMARY}

MidAmerican Energy

Louisa Generating Station

Unit 1 Stack

February 9, 2006

\begin{tabular}{|c|c|c|c|c|c|c|}
\hline \multirow[b]{2}{*}{ RUN \# } & \multirow[b]{2}{*}{ Time } & \multirow{2}{*}{$\begin{array}{c}\mathrm{CO}_{2} \\
\% \text { dry }\end{array}$} & \multirow{2}{*}{$\begin{array}{c}\mathrm{O}_{2} \\
\% \text { dry }\end{array}$} & \multirow{2}{*}{$\begin{array}{c}\text { Flow } \\
\text { dscfm }\end{array}$} & \multicolumn{2}{|c|}{$\mathrm{HCl}$} \\
\hline & & & & & ppm & $\mathrm{lb} / \mathrm{hr}$ \\
\hline 1 & $12: 25-13: 25$ & 13.9 & 5.6 & $1,737,321$ & 0.898 & 8.868 \\
\hline 2 & $14: 05-15: 05$ & 14.1 & 5.7 & $1,714,553$ & 0.651 & 6.345 \\
\hline 3 & $15: 39-16: 39$ & 14.0 & 5.6 & $1,769,099$ & 0.848 & 8.523 \\
\hline \multicolumn{2}{|c|}{ Average } & 14.0 & 5.6 & $1,740,324$ & 0.799 & 7.912 \\
\hline
\end{tabular}

\begin{tabular}{|c|c|c|c|c|c|c|}
\hline \multirow[b]{2}{*}{ RUN \# } & \multirow[b]{2}{*}{ Time } & \multirow{2}{*}{$\begin{array}{c}\mathrm{CO}_{2} \\
\% \text { dry }\end{array}$} & \multirow{2}{*}{$\begin{array}{c}\mathrm{O}_{2} \\
\% \text { dry }\end{array}$} & \multirow{2}{*}{$\begin{array}{c}\text { Flow } \\
\text { dscfm }\end{array}$} & \multicolumn{2}{|c|}{ HF } \\
\hline & & & & & ppm & $\mathrm{lb} / \mathrm{hr}$ \\
\hline 1 & $12: 25-13: 25$ & 13.9 & 5.6 & $1,737,321$ & 0.221 & 1.197 \\
\hline 2 & $14: 05-15: 05$ & 14.1 & 5.7 & $1,714,553$ & 0.219 & 1.173 \\
\hline 3 & $15: 39-16: 39$ & 14.0 & 5.6 & $1,769,099$ & 0353 & 1.950 \\
\hline \multicolumn{2}{|c|}{ Average } & 14.0 & 5.6 & $1,740,324$ & 0.265 & 1.440 \\
\hline
\end{tabular}

\begin{tabular}{|c|c|c|c|c|c|c|}
\hline \multirow{2}{*}{ RUN \# } & Time & \multirow{2}{*}{$\begin{array}{c}\mathrm{CO}_{2} \\
\% \text { dry }\end{array}$} & $\begin{array}{c}\mathrm{O}_{2} \\
\% \text { dry }\end{array}$ & $\begin{array}{c}\text { Flow } \\
\text { dscfm }\end{array}$ & \multicolumn{2}{|c|}{$\mathrm{HBr}$} \\
\hline 1 & $12: 25-13: 25$ & 13.9 & 5.6 & $1,737,321$ & 0.338 & 7.399 \\
\hline 2 & $14: 05-15: 05$ & 14.1 & 5.7 & $1,714,553$ & 0.434 & 9.384 \\
\hline 3 & $15: 39-16: 39$ & 14.0 & 5.6 & $1,769,099$ & 0.367 & 8.189 \\
\hline \multicolumn{2}{|l}{ Average } & 14.0 & 5.6 & $1,740,324$ & 0.380 & 8.324 \\
\hline
\end{tabular}

Note: $\quad$ Test 1 flow value is the average flow runs pre 1 .and post 1 .

Test 2 flow value is the average flow runs post 1 and post 2 .

Test 3 flow value is the average flow runs post 2 and post 3 . 


\section{GE Energy}

GASEOUS TEST RESULTS SUMMARY

MidAmerican Energy

Louisa Generating Station

Unit 1 Stack

February 9, 2006

\begin{tabular}{|c|c|c|c|c|c|c|}
\hline \multirow[b]{2}{*}{ RUN \# } & \multirow[b]{2}{*}{ Time } & \multirow{2}{*}{$\begin{array}{c}\mathrm{CO}_{2} \\
\% \text { dry }\end{array}$} & \multirow{2}{*}{$\begin{array}{c}\mathrm{O}_{2} \\
\% \text { dry }\end{array}$} & \multirow{2}{*}{$\begin{array}{c}\text { Flow } \\
\text { dscfm }\end{array}$} & \multicolumn{2}{|c|}{$\mathrm{Br}_{2}{ }^{*}$} \\
\hline & & & & & ppm & $\mathrm{lb} / \mathrm{hr}$ \\
\hline 1 & $11: 25-12: 25$ & 13.5 & 6.5 & $1,683,018$ & 0.063 & 2.720 \\
\hline 2 & $13: 15-14: 15$ & 13.5 & 6.5 & $1,685,823$ & 0.062 & 2.666 \\
\hline 3 & $14: 45-15: 45$ & 13.3 & 6.8 & $1,682,868$ & 0.063 & 2.785 \\
\hline \multicolumn{2}{|c|}{ Average } & 13.4 & 6.6 & $1,683,903$ & 0.063 & 2.724 \\
\hline
\end{tabular}

${ }^{*} \mathrm{Br}_{2}$ laboratory results are below the detection limit of $0.05 \mathrm{mg}$.

\begin{tabular}{|c|c|c|c|c|c|c|}
\hline \multirow[b]{2}{*}{ RUN \# } & \multirow[b]{2}{*}{ Time } & \multirow{2}{*}{$\begin{array}{c}\mathrm{CO}_{2} \\
\% \text { dry }\end{array}$} & \multirow{2}{*}{$\begin{array}{c}\mathrm{O}_{2} \\
\% \text { dry }\end{array}$} & \multirow{2}{*}{$\begin{array}{l}\text { Flow } \\
\text { dscfm }\end{array}$} & \multicolumn{2}{|c|}{$\mathrm{Cl}_{2}$} \\
\hline & & & & & ppm & $\mathrm{lb} / \mathrm{hr}$ \\
\hline 1 & $11: 25-12: 25$ & 13.5 & 6.5 & $1,683,018$ & 0.306 & 5.875 \\
\hline 2 & $13: 15-14: 15$ & 13.5 & 6.5 & $1,685,823$ & 0.065 & 1.226 \\
\hline 3 & $14: 45-15: 45$ & 13.3 & 6.8 & $1,682,868$ & 0.117 & 2.284 \\
\hline \multicolumn{2}{|c|}{ Average } & 13.4 & 6.6 & $1,683,903$ & 0.163 & 3.129 \\
\hline
\end{tabular}

Note: $\quad$ Test 1 flow value is the average flow runs pre 1 .and post 1 .

Test 2 flow value is the average flow runs post 1 and post 2 .

Test 3 flow value is the average flow runs post 2 and post 3 . 


\section{APPENDIX}




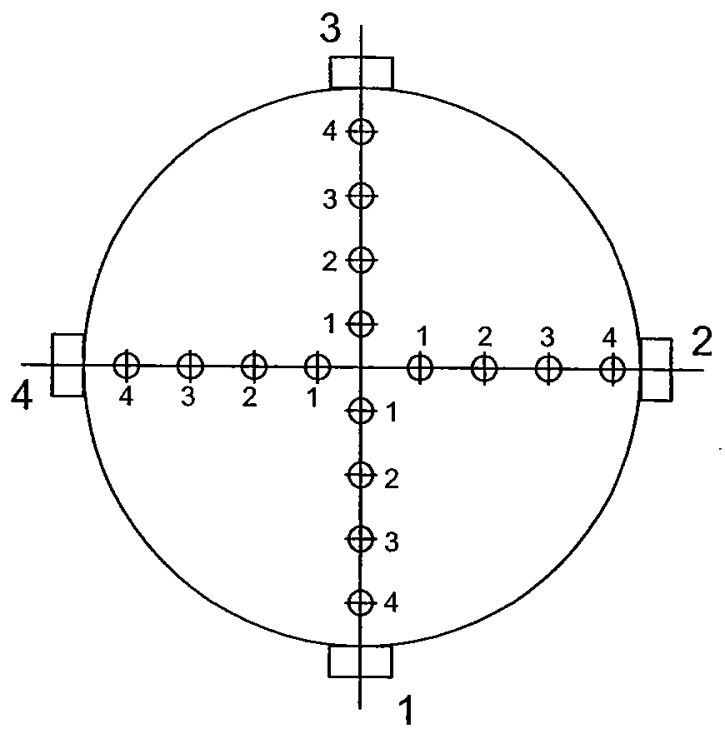

Job: MidAmerican Energy Louisa Generating Station Muscatine, lowa

Date: February 8 and 9, 2006

Test Location: Unit 1 Stack

Diameter: 32.15 Feet

Area: 811.81 Square Feet

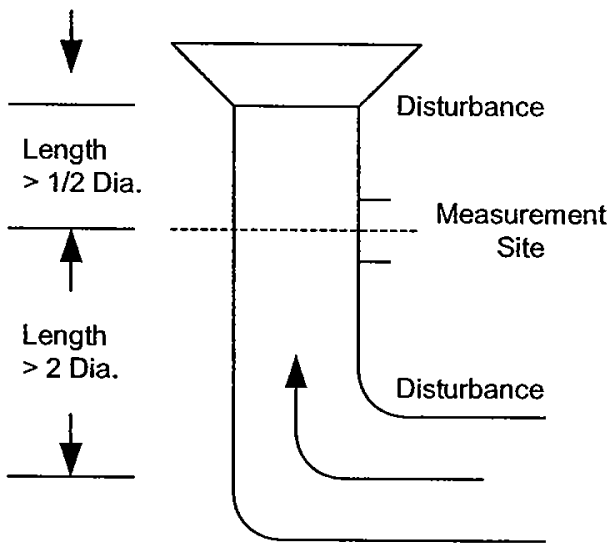

No. Points Across Diameter: 8

No. of Ports: 4 


\section{EQUAL AREA TRAVERSE FOR ROUND DUCTS}

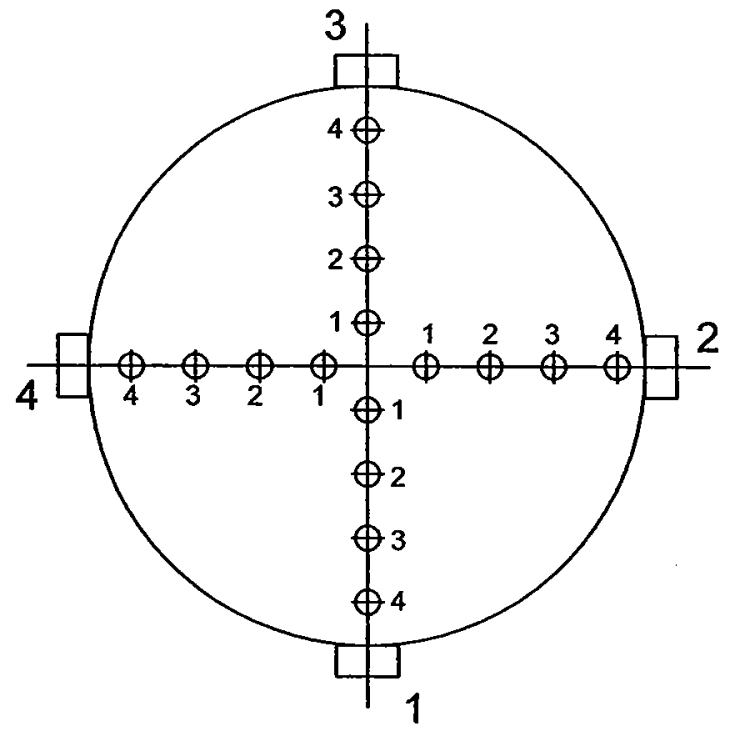

Job: MidAmerican Energy Louisa Generating Station Muscatine, lowa

Date: February 8 and 9, 2006

Test Location: Unit 1 Stack

Diameter: 32.15 Feet

Area: 811.81 Square Feet

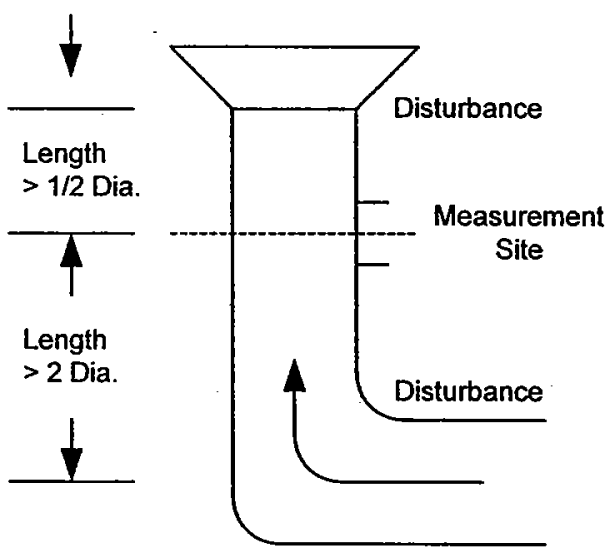

No. Points Across Diameter: 8

No. of Ports: 4 


\section{GE Energy}

\section{S-Type Pitot Tube Manometer Assembly}

\section{USEPA Method 2}

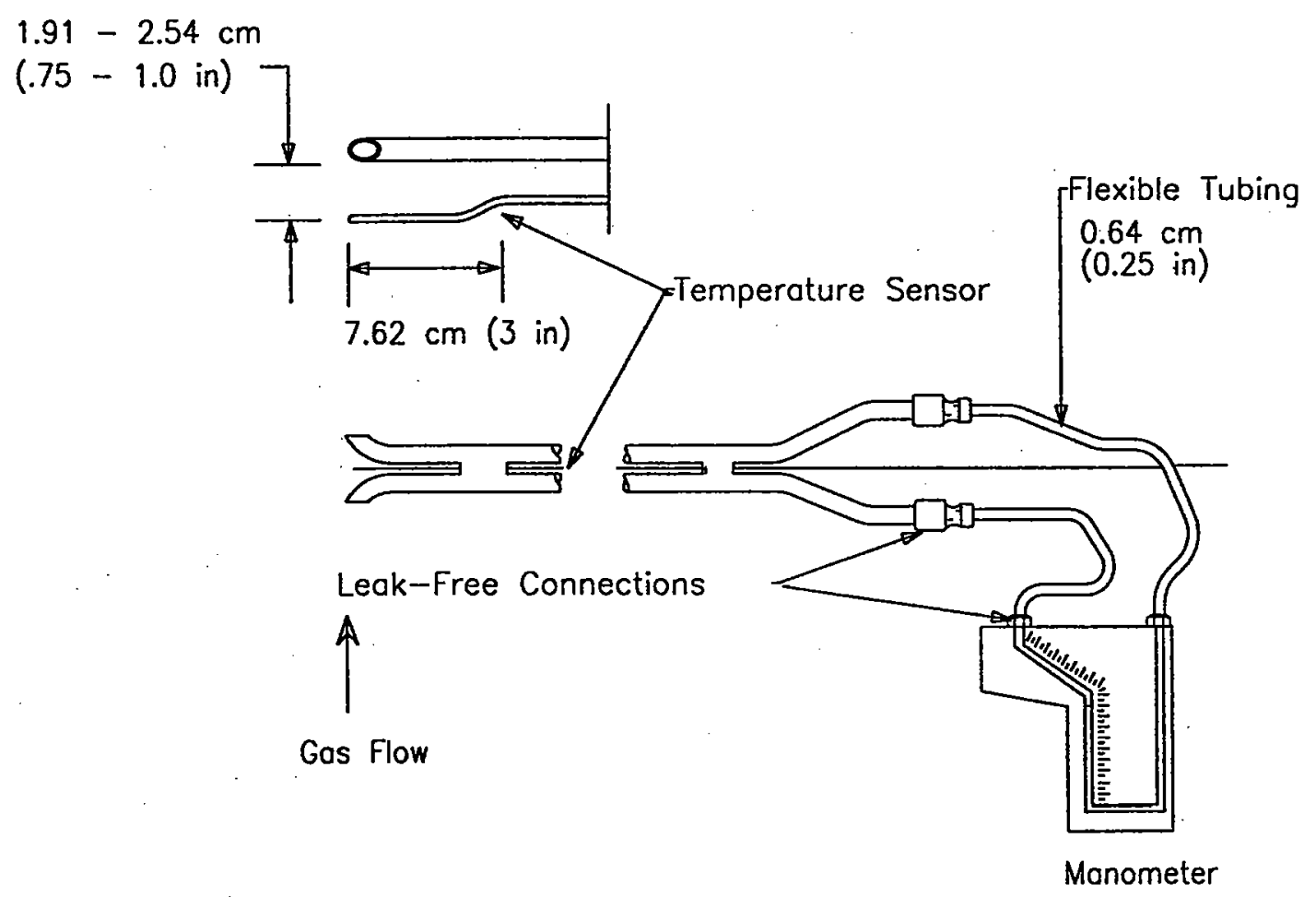

Dwg - AD 


\section{GE Energy}

\section{Sampling Train for Integrated Gas Sampling}

\section{USEPA Method 3}

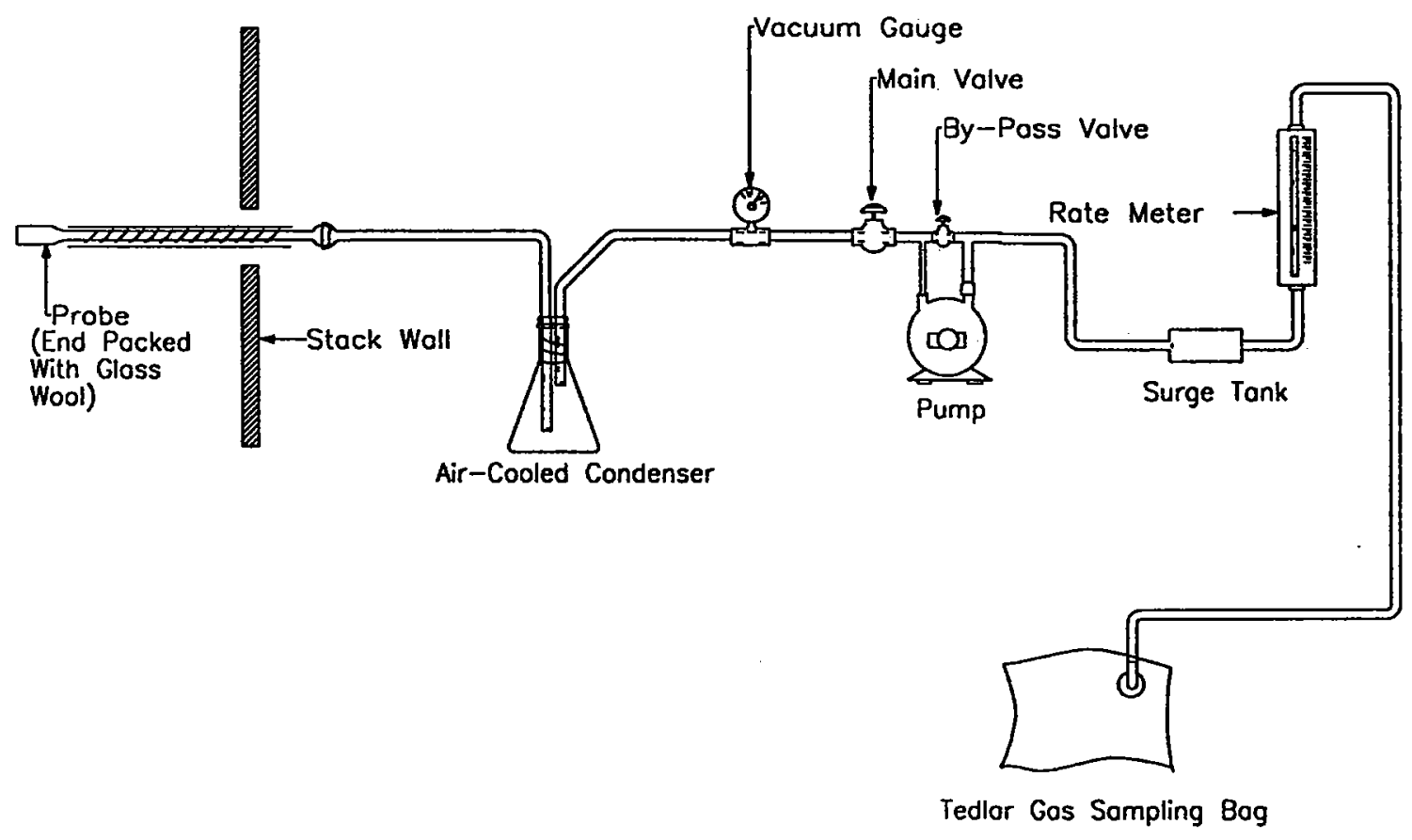

Dwg - E 


\section{GE Energy}

\section{Determination of $\mathrm{HCl}, \mathrm{HF}, \mathrm{HBr}, \mathrm{Br}_{2}$ and $\mathrm{Cl}_{2}$ Concentrations in Stack Gases}

\section{USEPA Method 26A Sample Train}

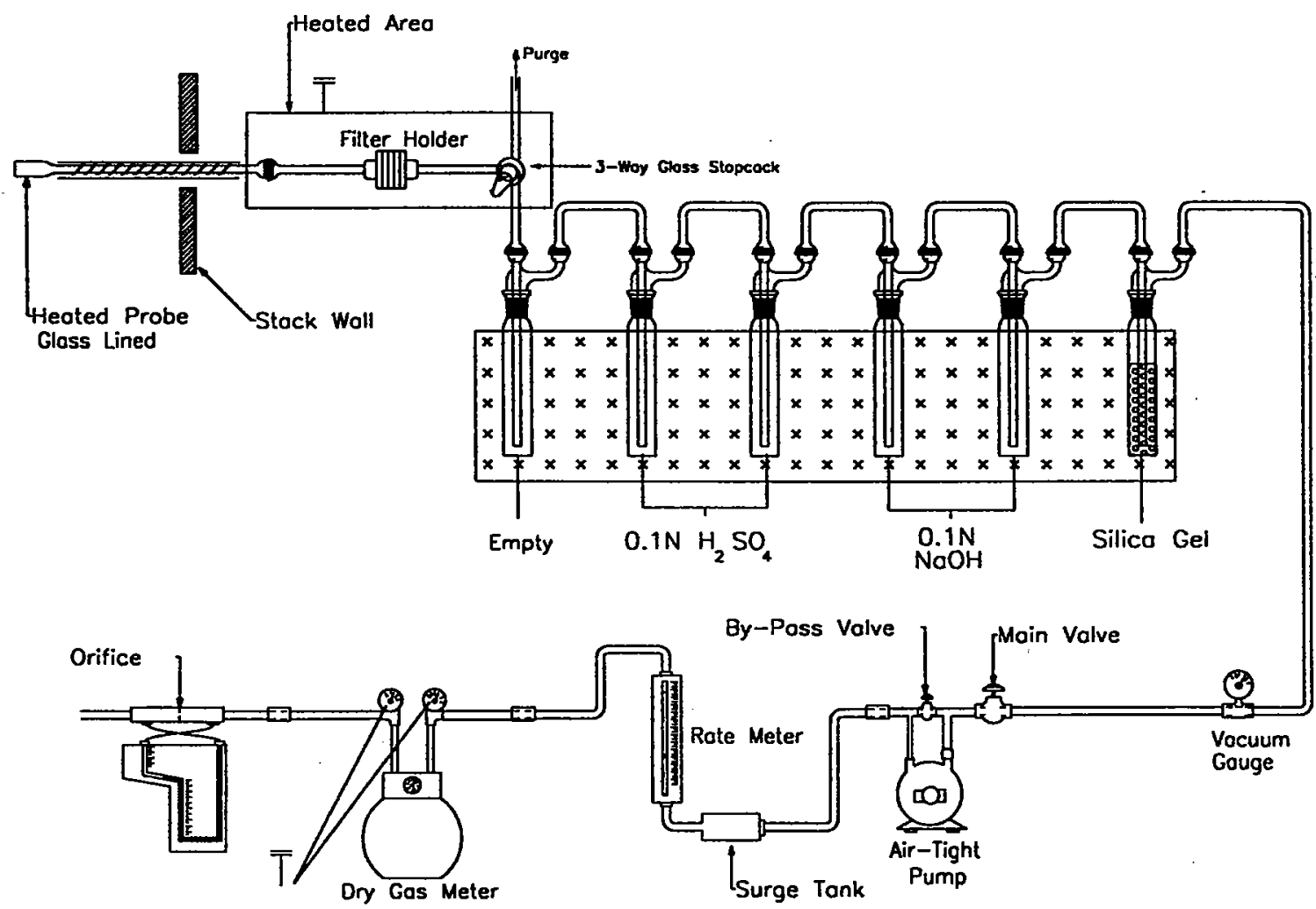

E:=3 Ice Both

T Temperoture

Dwg - R 


\section{LABORATORY REPORT}

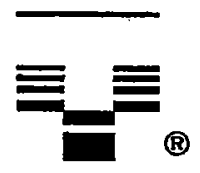

TEl Analytical, Inc.

7177 N. Austin

Niles, IL 60714-4617

847-647-1345

PREPARED FOR:

PAGE 1 of 4

Frank Jarke

GE Energy Management Services, Inc.

888 Industrial Dr.

Elmhurst, IL 60126
Report \#: 70899

Report Date: 2/22/2006

Sample Received:

2/13/06 12:19

\section{M22E1180-02}

$2 / 8$ TEI Number: 70899 Sample: 001 TH

TEST

$\mathrm{HBr}(\mathrm{M} 26 \mathrm{~A})$

$\mathrm{HCl}$ (M26A)

HF (M26A)

2/8 TEI Number: 70900 Sample: 002 T 2

TEST

$\mathrm{HBr}$ (M26A)

$\mathrm{HCl}(\mathrm{M} 26 \mathrm{~A})$

HF (M26A)

$2 / 8$ TEI Number: 7090

TEST

$\mathrm{HBr}(\mathrm{M} 26 \mathrm{~A})$

$\mathrm{HCl}$ (M26A)

HF (M26A)
RESULTS

$<0.05$

0.125

0.034

RESULTS

$<0.05$

0.456

0.028

Sample: 003 T3

RESULTS

$<0.05$

0.116

0.028
DATE PERFORMED

$\mathrm{mg} \quad 2 / 15 / 2006$

$\mathrm{mg} \quad 2 / 15 / 2006$

$\mathrm{mg} \quad 2 / 15 / 2006$
DATE PERFORMED

mg

$\mathrm{mg}$

$\mathrm{mg}$

2/15/2006

$2 / 15 / 2006$

2/15/2006

\section{DATE PERFORMED}

2/15/2006

2/15/2006

2/15/2006

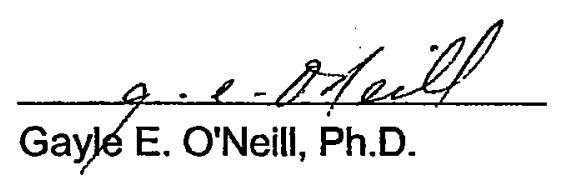

This report may not be reprdffuced except in its entirety. 


\section{LABORATORY REPORT}

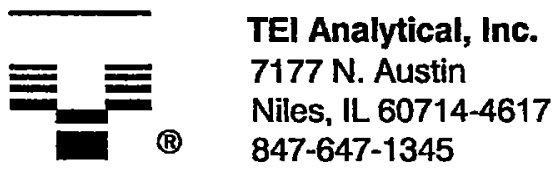

PREPARED FOR:

PAGE 2 of 4

Frank Jarke

GE Energy Management Services, Inc.

888 Industrial Dr.

Elmhurst, IL 60126
Report \#: 70899

Report Date: 2/22/2006

Sample Received:

2/13/06 12:19

\section{M22E1180-02}

$2 / 9$

TEl Number: $\quad 70902$

TEST

$\mathrm{HBr}$ (M26A)

$\mathrm{HCl}(\mathrm{M} 26 \mathrm{~A})$

HF (M26A)

$219 \begin{aligned} & \text { TEI Number: } \\ & \text { TEST }\end{aligned}$

$\mathrm{HBr}(\mathrm{M} 26 \mathrm{~A})$

$\mathrm{HCl}(\mathrm{M} 26 \mathrm{~A})$

HF (M26A)

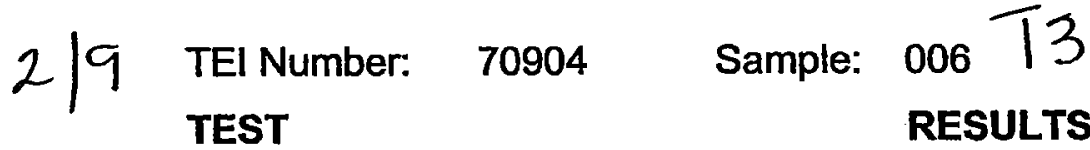

$\mathrm{HBr}(\mathrm{M} 26 \mathrm{~A})$

$\mathrm{HCl}(\mathrm{M} 26 \mathrm{~A})$

HF (M26A)
Sample: $004 T$ |

RESULTS

0.136

0.163

0.022

$\mathrm{mg}$

$\mathrm{mg}$

mg

DATE PERFORMED

2/15/2006

$2 / 15 / 2006$

2/15/2006
RESULTS

0.176

0.119

0.022

$\mathrm{mg}$

$\mathrm{mg}$

$\mathrm{mg}$

DATE PERFORMED

2/15/2006

$2 / 15 / 2006$

$2 / 15 / 2006$

RESULTS

0.147

0.153

0.035
DATE PERFORMED

$\mathrm{mg}$

mg

mg
2/15/2006

$2 / 15 / 2006$

$2 / 15 / 2006$

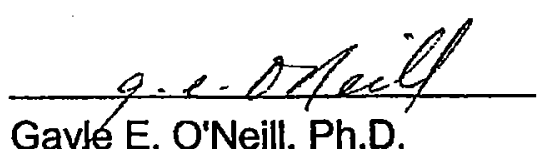

This report may not be repreduced except in its entirety. 


\section{LABORATORY REPORT}

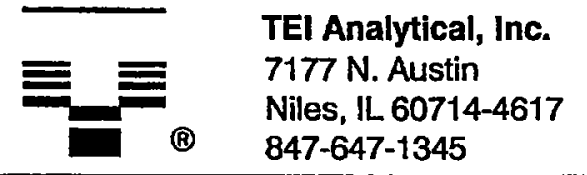

PREPARED FOR:

PAGE 3 of 4

Frank Jarke

Report \#: 70899

GE Energy Management Services, Inc.

Report Date: 2/22/2006

888 Industrial Dr.

Elmhurst, IL 60126

Sample Received:

2/13/06 12:19

M22E1180-02

TEI Number: 70905 Sample: 007 blank

TEST

$\mathrm{HBr}(\mathrm{M} 26 \mathrm{~A})$

$\mathrm{HCl}$ (M26A)

HF (M26A)

$2 / 8$

TEI Number: 70906

TEST

Bromine (M26A)

Chlorine (M26A)

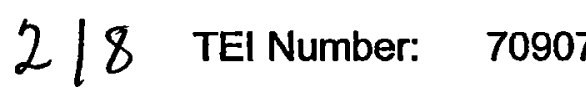

TEST

Bromine (M26A)

Chlorine (M26A)

$2 / 8$ TEI Number: 70908

TEST

Bromine (M26A)

Chlorine (M26A)
RESULTS

$<0.05$

$<0.01$

$<0.01$

Sample: 008 T

RESULTS

$<0.05$

0.117

Sample: $009 T 2$

RESULTS

$<0.05$

0.133

Sample: 010 T3

RESULTS

$<0.05$

0.046
DATE PERFORMED

mg

$\mathrm{mg}$

$\mathrm{mg}$

2/15/2006

2/15/2006

2/15/2006

DATE PERFORMED

mg

$\mathrm{mg}$

$2 / 15 / 2006$

$2 / 15 / 2006$
DATE PERFORMED

$\mathrm{mg}$

$\mathrm{mg}$

2/15/2006

DATE PERFORMED

2/15/2006

$2 / 15 / 2006$

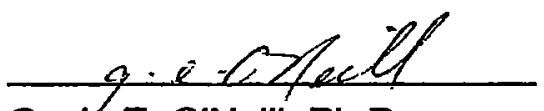

Gayle E. O'Neill, Ph.D.

This report may not be reprb8uced except in its entirety. 


\section{LABORATORY REPORT}

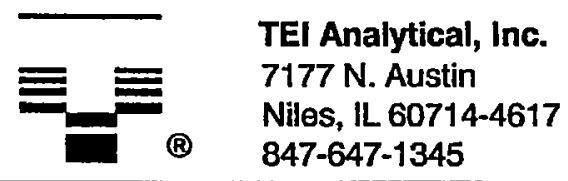

PREPARED FOR:

PAGE 4 of 4

Frank Jarke

GE Energy Management Services, Inc.

888 Industrial Dr.

Elmhurst, IL 60126
Report \#: 70899

Report Date: 2/22/2006

Sample Received:

2/13/06 12:19

\section{M22E1180-02}

$2 / 9 \begin{aligned} & \text { TEI Number: } 70909 \quad \text { Sample: } \\ & \text { TEST }\end{aligned}$

Bromine (M26A)

Chlorine (M26A)

$2 / 9$ TEI Number: 70910

\section{TEST}

Bromine (M26A)

Chlorine (M26A)

$2 / 9$ TEI Number: 70911

TEST

Bromine (M26A)

Chlorine (M26A)

TEI Number: 70912

TEST

Bromine (M26A)

Chlorine (M26A)
RESULTS

$<0.05$

0.108

Sample: 012 T2

RESULTS
$<0.05$
0.023

Sample: 013 T3

RESULTS

$$
<0.05
$$

0.041

$\mathrm{mg}$

$\mathrm{mg}$

DATE PERFORMED

2/16/2006

$2 / 16 / 2006$
DATE PERFORMED

2/16/2006

$2 / 16 / 2006$

Sample: 014 blank

RESULTS

$<0.05$

$<0.01$
DATE PERFORMED

$2 / 16 / 2006$

$2 / 16 / 2006$

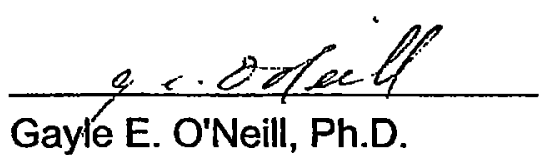

This report may not be reprbauced except in its entirety. 


\section{GE Energy}

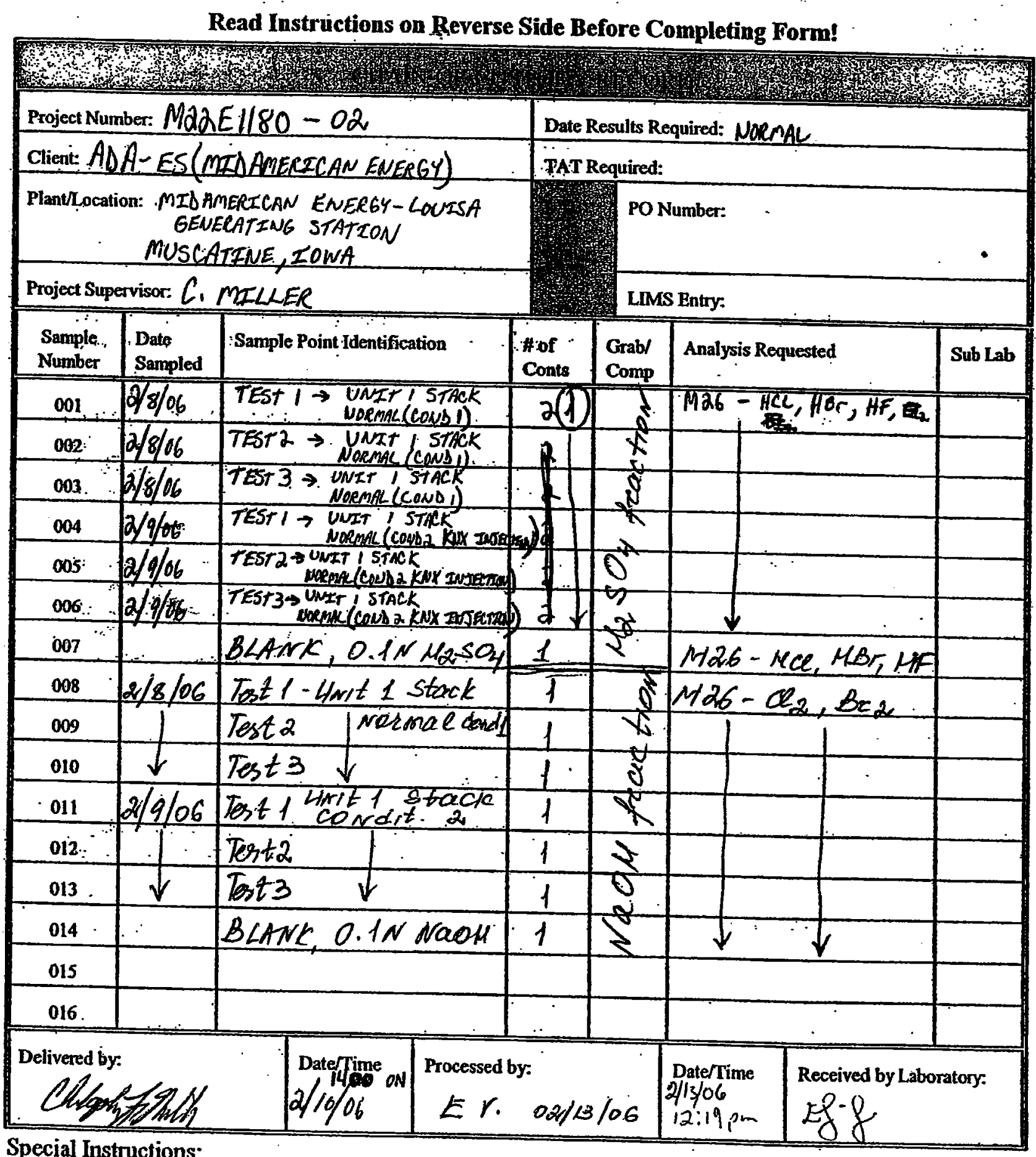


in

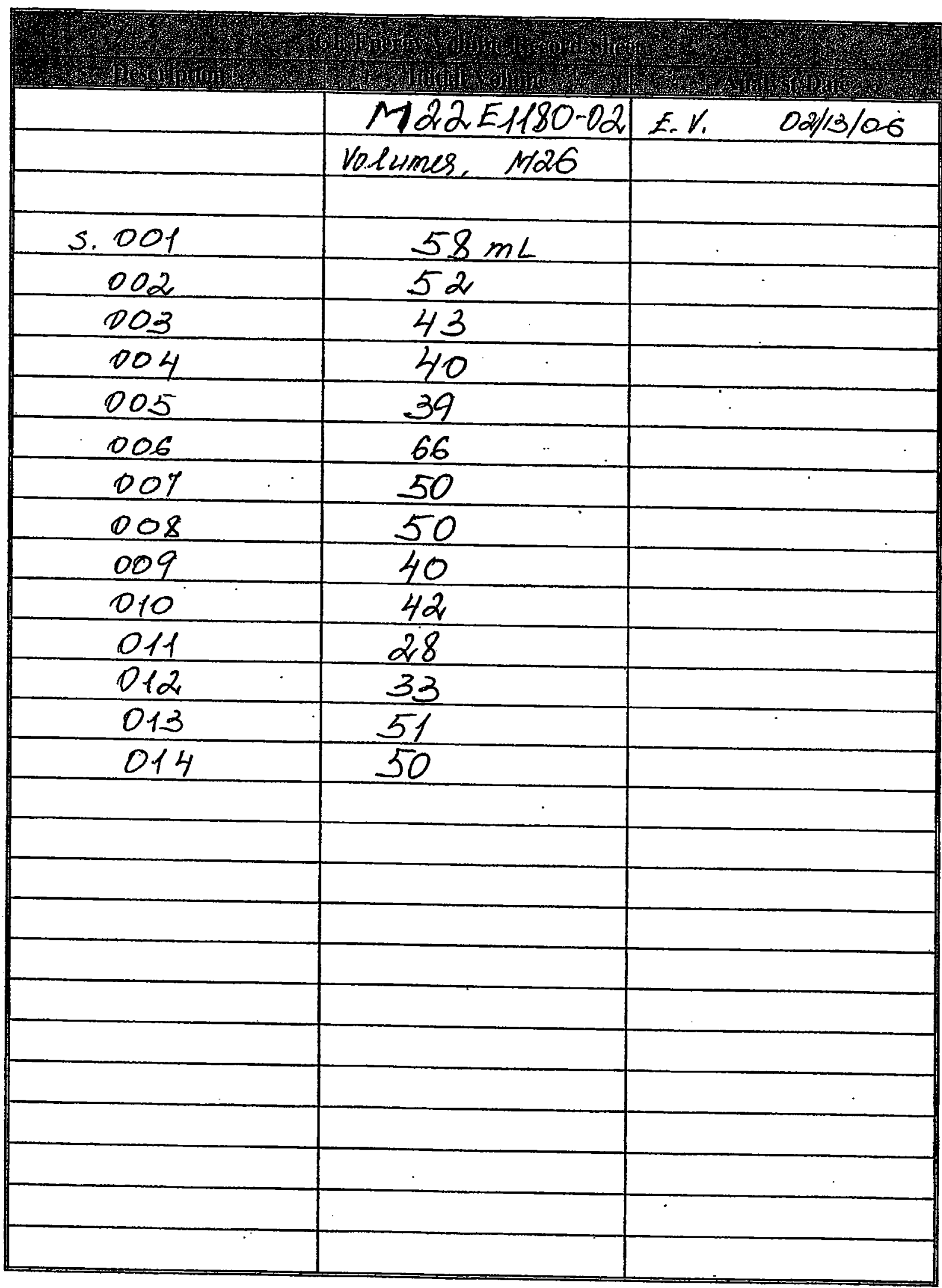




\section{Example Calculations - Volumetric Flow}

\section{Company: MidAmerican}

Plant: Louisa Generating Station

Source: $\quad$ Unit 1 Stack

Run: $\quad$ Normal Load, Run Pre 1

Date: $\quad 02 / 08 / 06$

Moisture Content

$$
\begin{aligned}
V m(s t d) & =17.647 \times V m \times \frac{P b+\frac{\Delta H}{13.6}}{(460+T m)} \times Y d \\
V w(s t d) & =\left(0.04707 \times V i c \text { silica net } \mathrm{H}_{2} \mathrm{O}\right)+\left(0.04715 \times \text { Vlc net } \mathrm{H}_{2} \mathrm{O}\right) \\
B w s & =\frac{V w(s t d)}{V w(s t d)+V m(s t d)} \\
V w(s t d) & =\frac{0.528}{\text { Bws }}=\frac{\mathbf{0 . 1 1 4}}{\mathrm{V}(\mathrm{std})=4.093}
\end{aligned}
$$

Dry Molecular Weight

$$
\begin{aligned}
\mathrm{Md} & =0.44 \times\left(\% \mathrm{CO}_{2}\right)+0.32 \times\left(\% \mathrm{O}_{2}\right)+0.28 \times \% \mathrm{~N}_{2} \\
\% \mathrm{CO}_{2} & =\frac{13.5}{30.42} \quad \% \mathrm{O}_{2}=\frac{6.5}{\mathrm{Md}_{2}=}=80.0 \\
& =\frac{30.42}{}
\end{aligned}
$$

Wet Molecular Weight

$$
\begin{aligned}
& M s=M d \times(1-B w s)+(18.0 \times B w s) \\
& M d=\frac{30.42}{29.00} \quad B w s=0.114 \\
& M s=
\end{aligned}
$$

\section{Average Duct Velocity}

$$
\begin{aligned}
& V s=85.49 \times C p \times \text { Sqrt } \Delta P(\text { avg }) \times((T s(\text { avg })+460) /(P s \times M s))^{1 / 2} \\
& C p=\frac{0.840}{29.84} \text { Ts (avg) }=\frac{297.7}{29.00} \text { Sqrt } \Delta P \text { avg: } \quad 0.846 \\
& P s=\frac{56.83}{V s}=
\end{aligned}
$$

\section{Volumetric Flow Rate}

$$
\begin{aligned}
Q \text { (Actual Basis) } & =V s \times A \times 60 \\
V s & =\frac{56.83}{\mathbf{Q}}=\mathbf{2 7 6 8 1 5 7} \mathbf{a c f m}
\end{aligned}
$$

$$
\text { Qs (Standard Basis) }=17.647 \times \quad Q \quad \times \frac{\text { Ps }}{460+\text { Ts (avg) }}
$$

$$
\begin{aligned}
Q & =\frac{2768157}{1923795} \mathrm{scfm} \\
Q s & =\underline{1923}=\underline{29.84} \text { Ts (avg) }=\underline{297.7}
\end{aligned}
$$

Qs (Standard Basis) $=\mathrm{scfm} \times 60 \mathrm{~min} / \mathrm{hr}$

$$
Q s=\underline{115427720} \mathrm{scth}
$$




\section{Example Calculations \\ MidAmerican Energy \\ Louisa Generating Station - Unit 1 Stack \\ February 8, 2006 - Test 1}

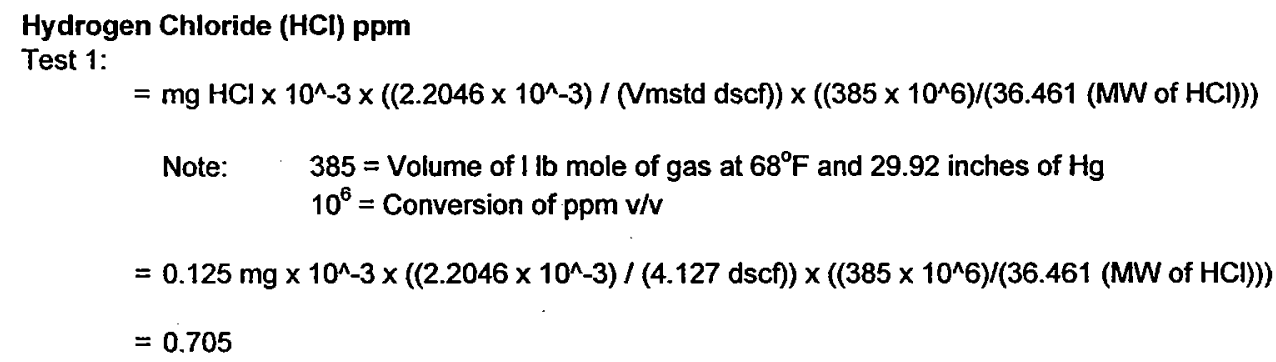

Hydrogen Chloride $(\mathrm{HCl}) \mathrm{lb} / \mathrm{hr}$

Test 1:

$=\mathrm{mg} \mathrm{HCl} \times 10^{\wedge}-3 \times\left(\left(2.2046 \times 10^{\wedge}-3\right) /(\right.$ Vmstd dscf $\left.)\right) \times \mathrm{dscfm} \times 60 \mathrm{~min} / \mathrm{hr}$

$=0.125 \mathrm{mg} \times 10^{\wedge}-3 \times\left(\left(2.2046 \times 10^{\wedge}-3\right) /(4.127 \mathrm{dscf})\right) \times 1,683,018 \mathrm{dscfm} \times 60 \mathrm{~min} / \mathrm{hr}$

$=6.743$

Hydrogen Fluoride (HF) ppm

Test 1:

$=m g \mathrm{HF} \times 10^{\wedge}-3 \times\left(\left(2.2046 \times 10^{\wedge}-3\right) /(\mathrm{Vmstd} \mathrm{dscf})\right) \times\left(\left(385 \times 10^{\wedge} 6\right) /(20.006(\mathrm{MW}\right.$ of HF) $))$

$=0.034 \mathrm{mg} \times 10^{\wedge}-3 \times\left(\left(2.2046 \times 10^{\wedge}-3\right) /(4.127 \mathrm{dscf})\right) \times\left(\left(385 \times 10^{\wedge} 6\right) /(20.006(\mathrm{MW} \mathrm{of} \mathrm{HF}))\right.$

$=0.350$

Hydrogen Fluoride (HF) lb/hr

Test 1:

$=\mathrm{mg} \mathrm{HF} \times 10^{\wedge}-3 \times\left(\left(2.2046 \times 10^{\wedge}-3\right) /(\mathrm{Vmstd} \mathrm{dscf})\right) \times \mathrm{dscfm} \times 60 \mathrm{~min} / \mathrm{hr}$

$=0.034 \mathrm{mg} \times 10^{\wedge}-3 \times\left(\left(2.2046 \times 10^{\wedge}-3\right) /(4.127 \mathrm{dscf})\right) \times 1,683,018 \mathrm{dscfm} \times 60 \mathrm{~min} / \mathrm{hr}$

$=1.834$

Hydrogen Bromide ( $\mathrm{HBr}$ ) ppm

Test 1:

$=\mathrm{mg} \mathrm{HBr} \times 10^{\wedge}-3 \times\left(\left(2.2046 \times 10^{\wedge}-3\right) /(\right.$ Vmstd dscf $\left.)\right) \times\left(\left(385 \times 10^{\wedge} 6\right) /(80.917(\mathrm{MW}\right.$ of $\left.\mathrm{HBr}))\right)$

$=0.050 \mathrm{mg} \times 10^{\wedge}-3 \times\left(\left(2.2046 \times 10^{\wedge}-3\right) /(4.127 \mathrm{dscf})\right) \times\left(\left(385 \times 10^{\wedge} 6\right) /(80.917(\mathrm{MW}\right.$ of HBr $\left.))\right)$

Note: Laboratory results are below the detection limit of $0.05 \mathrm{mg}$.

$=0.127$

Hydrogen Bromide ( $\mathrm{HBr}$ ) lb/hr

Test 1:

$=\mathrm{mg} \mathrm{HBr} \times 10^{\wedge}-3 \times\left(\left(2.2046 \times 10^{\wedge}-3\right) /(\mathrm{Vmstd} \mathrm{dscf})\right) \times \mathrm{dscfm} \times 60 \mathrm{~min} / \mathrm{hr}$

$=0.050 \mathrm{mg} \times 10^{\wedge}-3 \times\left(\left(2.2046 \times 10^{\wedge}-3\right) /(4.127 \mathrm{dscf})\right) \times 1,683,018 \mathrm{dscfm} \times 60 \mathrm{~min} / \mathrm{hr}$

$=2.697$ 


\section{Example Calculations \\ MidAmerican Energy \\ Louisa Generating Station - Unit 1 Stack \\ February 8, 2006 - Test 1}

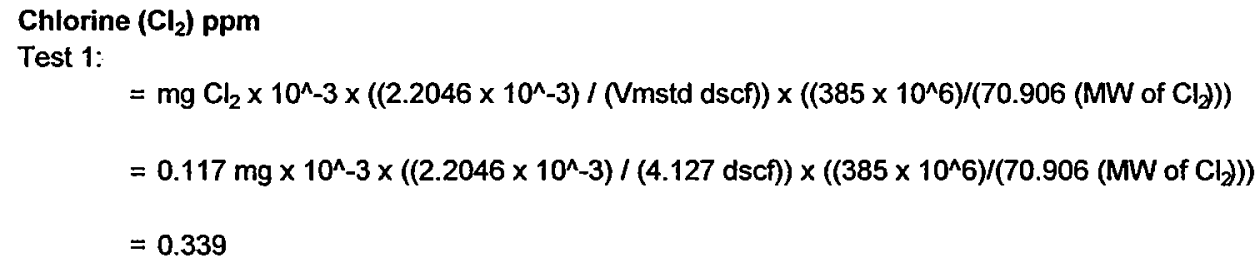

Chlorine $\left(\mathrm{Cl}_{2}\right) \mathrm{lb} / \mathrm{hr}$

Test 1:

$=m g \mathrm{Cl}_{2} \times 10^{\wedge}-3 \times\left(\left(2.2046 \times 10^{\wedge}-3\right) /(\mathrm{Vmstd} \mathrm{dscf})\right) \times \mathrm{dscfm} \times 60 \mathrm{~min} / \mathrm{hr}$

$=0.117 \mathrm{mg} \times 10^{\wedge}-3 \times\left(\left(2.2046 \times 10^{\wedge}-3\right) /(4.127 \mathrm{dscf})\right) \times 1,683,018 \mathrm{dscfm} \times 60 \mathrm{~min} / \mathrm{hr}$

$=6.311$

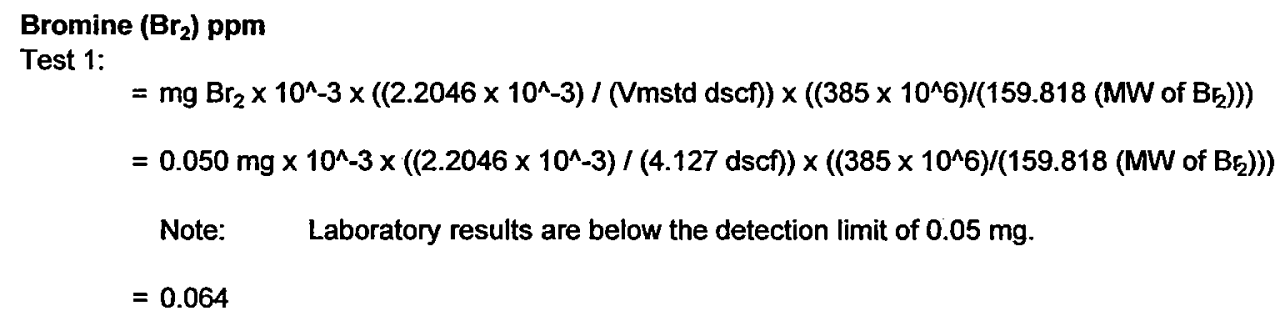




\section{VOLUMETRIC AIR FLOW CALCULATIONS}

$\mathrm{Vm}(\mathrm{std})=17.647 \times \mathrm{Vm} \times\left[\frac{\mathrm{P}_{\mathrm{bar}}+\frac{\mathrm{DH}}{13.6}}{(460+\mathrm{Tm})}\right] \times \mathrm{Y}$

$V_{w}(\mathrm{std})=0.0471 \times \mathrm{Vlc}$

Vlc $=$ water + silica net

$$
\begin{aligned}
& \mathrm{Bws}=\left[\frac{\mathrm{Vw}(\mathrm{std})}{\mathrm{Vw}(\mathrm{std})+\mathrm{Vm}(\mathrm{std})}\right] \\
& \mathrm{Md}=\left(0.44 \times \% \mathrm{CO}_{2}\right)+\left(0.32 \times \% \mathrm{O}_{2}\right)+\left[0.28 \times\left(100-\% \mathrm{CO}_{2}-\% \mathrm{O}_{2}\right)\right] \\
& \mathrm{MS}=\mathrm{Md} \times(1-\mathrm{Bws})+(18 \times \mathrm{Bws}) \\
& \mathrm{Vs}=\sqrt{\frac{(\mathrm{Ts}+460)}{\mathrm{Ms} \times \mathrm{Ps}}} \times \sqrt{\mathrm{DP}} \times \mathrm{Cp} \times 85.49 \quad \mathrm{Cp}=\text { pitot tube correction factor } \\
& \text { Ps = absolute flue gas pressure } \\
& \mathrm{Ms}=\text { molecular weight of gas ( } \mathrm{lb} / \mathrm{lb} \text { mole) } \\
& \mathrm{Md}=\text { dry molecular weight of gas } \\
& \text { (lb/lb mole) } \\
& \text { Bws }=\text { water vapor in gas stream proportion } \\
& \text { Acfm }=\text { Vs } \times \text { Area (of stack or duct) } \times 60 \\
& \text { by volume }
\end{aligned}
$$

$$
\begin{aligned}
& \text { Dscfm }=\operatorname{Acfm} \times 17.647 \times\left[\frac{\text { Ps }}{(460+\mathrm{Ts})}\right] \times(1-\mathrm{Bws}) \\
& \operatorname{Scfm}=\operatorname{Acfm} \times 17.647 \times\left[\frac{\mathrm{Ps}}{(460+\mathrm{Ts})}\right] \\
& \mathrm{Scfh}=\operatorname{Scfm} \times 60 \frac{\mathrm{min}}{\mathrm{hr}}
\end{aligned}
$$




\section{MOISTURE CALCULATIONS}

$$
\begin{aligned}
& \mathrm{V}_{\mathrm{w}(\mathrm{std})}=\frac{\left(\mathrm{V}_{\mathrm{f}}-\mathrm{V}_{\mathrm{i}}\right) \rho_{\mathrm{w}} \mathrm{RT}_{\mathrm{std}}}{\mathrm{P}_{\mathrm{std}} \mathrm{M}_{\mathrm{w}}}=0.04707\left(\mathrm{~V}_{\mathrm{f}}-\mathrm{V}_{\mathrm{i}}\right) \\
& V_{\text {wgg(std) }}=\frac{\left(\mathrm{W}_{\mathrm{f}}-\mathrm{W}_{\mathrm{i}}\right) \mathrm{RT}_{\mathrm{std}}}{\mathrm{P}_{\mathrm{std}} \mathrm{M}_{\mathrm{w}}}=0.04715\left(\mathrm{~W}_{\mathrm{f}}-\mathrm{W}_{\mathrm{i}}\right) \\
& \mathrm{V}_{\mathrm{m}(\mathrm{std})}=17.64 \mathrm{~V}_{\mathrm{m}} \mathrm{Y} \frac{\mathrm{P}_{\mathrm{bar}}+\frac{\Delta \mathrm{H}}{13.6}}{\mathrm{~T}_{\mathrm{m}}} \\
& B_{\mathrm{ws}}=\frac{\mathrm{V}_{\mathrm{wc}(\mathrm{std})}+\mathrm{V}_{\mathrm{wsg}(\mathrm{std})}}{\mathrm{V}_{\mathrm{wc}(\mathrm{std})}+\mathrm{V}_{\mathrm{wsg}(\mathrm{std})}+\mathrm{V}_{\mathrm{m}(\mathrm{std})}}
\end{aligned}
$$

Where:

$\mathrm{B}_{\mathrm{ws}}=$ Water vapor in gas stream, proportion by volume

$\mathrm{M}_{\mathrm{w}}=$ Molecular weight of water, $18.015 \mathrm{lb} / \mathrm{lb}$-mole

$\mathrm{P}_{\mathrm{bar}}=$ Barometric pressure at the testing site, in. $\mathrm{Hg}$

$P_{\text {std }}=$ Standard absolute pressure, 29.92 in. $\mathrm{Hg}$

$\mathrm{R}=$ Ideal gas constant, $0.048137($ in. $\mathrm{Hg})\left(\mathrm{ft}^{3}\right) /(\mathrm{g}$-mole $)\left({ }^{\circ} \mathrm{R}\right)=$ [21.8348(in. Hg)(ft $\left.{ }^{3}\right) /(\mathrm{lb}-$ mole $\left.)\left({ }^{\circ} \mathrm{R}\right)\right] / 453.592 \mathrm{~g}$-mole/lb-mole

$\mathrm{T}_{\mathrm{m}}=$ Absolute average dry gas meter temperature, ${ }^{\circ} \mathrm{R}$

$\mathrm{T}_{\text {std }}=$ Standard absolute temperature, $528^{\circ} \mathrm{R}$

$\mathrm{V}_{\mathrm{f}}=$ Final volume of condenser water, $\mathrm{ml}$

$V_{i}=$ Initial volume of condenser water, $\mathrm{ml}$

$\mathrm{V}_{\mathrm{m}}=$ Dry gas volume measured by dry gas meter, dcf

$\mathrm{V}_{\mathrm{m}(\mathrm{std})}=$ Dry gas volume measured by dry gas meter, corrected to standard conditions, scf

$\mathrm{V}_{\mathrm{wc}(\mathrm{std})}=$ Volume of condensed water vapor, corrected to standard conditions, scf

$\mathrm{V}_{\mathrm{wsg}(\mathrm{std})}=$ Volume of water vapor collected in silica gel, corrected to standard conditions, scf

$\mathrm{W}_{\mathrm{f}}=$ Final weight of silica gel, $\mathrm{g}$

$\mathrm{W}_{\mathrm{i}}=$ Initial weight of silica gel, $\mathrm{g}$

$\mathrm{Y}=$ Dry gas meter calibration factor

$\Delta \mathrm{H}=$ Average pressure exerted on dry gas meter outlet by gas sample bag, in. $\mathrm{H}_{2} \mathrm{O}$

$\rho_{\mathrm{w}}=$ Density of water, $0.9982 \mathrm{~g} / \mathrm{ml}$

$13.6=$ Specific gravity of mercury $(\mathrm{Hg})$

$17.64=\mathrm{T}_{\text {std }} / \mathrm{P}_{\text {std }}$

$0.04707=\mathrm{ft}^{3} / \mathrm{ml} \quad 0.04715=\mathrm{ft}^{3} / \mathrm{g}$ 
METHOD 26 TEST RESULTS

$\begin{array}{llll}\text { Date: } & \text { 2/8/2006 } & \text { Condition: } & \text { Normal } \\ \text { Project: } & \text { MidAmerican } & \text { Data Taken By: } & \text { CFMMMK } \\ \text { Location: } & \text { Louisa Generating Station } & \text { Fuel Factor: } & \text { N/A } \\ \text { Source: } & \text { Unit 1 Stack } & & \end{array}$

\begin{tabular}{|c|c|c|c|c|}
\hline Test Number: & 1 & Time: & \multicolumn{2}{|c|}{$11: 25-12: 25$} \\
\hline Pressure, Barometric(Hg"):......................... & 29.920 & \multicolumn{3}{|c|}{ Carbon Dioxide Content(\%):........................................ } \\
\hline 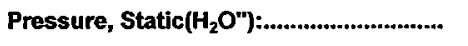 & -1.10 & Oxyget & ............... & 6.50 \\
\hline Pressure, Stack(Hg"):................................ & 29.839 & Nitroge & (....................... & 80.00 \\
\hline 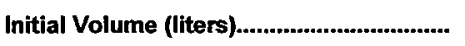 & 6737.29 & HF (mg & .......... & 0.034 \\
\hline Final Volume (liters) ..................................... & 6857.49 & $\mathrm{HCl}(\mathrm{m}$ & .............. & \\
\hline 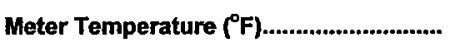 & 90.23 & Water & (n)................ & $0: 1$ \\
\hline 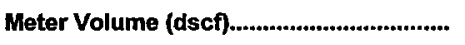 & 4.127 & HF (pp & (n................ & 35 \\
\hline 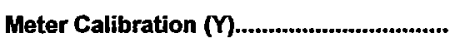 & 1.007 & $\mathrm{HCl}$ (Pr & .................... & 0.705 \\
\hline Initial Wt. (grms or mls) & 826.6 & HF (lbs & (n)................... & 1.834 \\
\hline Final Wt. (grms or mls) & 837.8 & $\mathrm{HCl}(\mathrm{lb}$ & .................. & 6.743 \\
\hline Average Delta $\mathrm{H}(\Delta \mathrm{H}) \ldots \ldots$ & 2.500 & HF (lbs & ..................... & $\mathbf{N} / \mathbf{A}$ \\
\hline Dry Standard Flow Rate (dscfm): "........... & $1,683,018$ & $\mathrm{HCl}(\mathrm{lb}$ & (.................... & N/A \\
\hline
\end{tabular}

- Test 1 flow value is the average flow runs pre 1 and post 1.

Test Number:

Pressure, Barometric(Hg"):........................

Pressure, Static $\left(\mathrm{H}_{2} \mathrm{O}\right.$ "):..............................

Pressure, Stack(Hg"):..................................

Initial Volume (liters)..................................

Final Volume (liters).....................................

Meter Temperature $\left({ }^{\circ} \mathrm{F}\right)$..............................

Meter Volume (dscf)..

Meter Calibration ( $Y$ ).

Initial Wt. (grms or mls).

Final Wt. (grms or $\mathrm{mls}$ ).

Average Delta $\mathrm{H}(\Delta \mathrm{H})$.......

Dry Standard Flow Rate (dscfm): •
2

29.920

$-1.10$

29.839

6858.12

6978.37

96.77

4.080

1.007

670.5

679.7

2.500

$1,685,823$
Time:

13:15-14:15

Garbon Dioxide Content(\%):...................................... 13.50

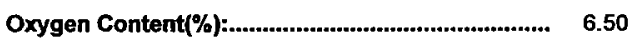

Nitrogen Content(\%):............................................ $\quad 80.00$

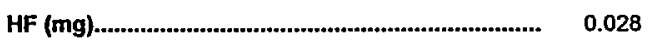

HCl (mg)............................................................. 0.456

Water Vapor in Flue Gas (Bws):.............................. 0.096

HF (ppm):............................................................ 0.291

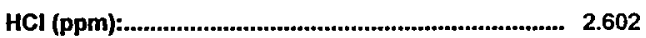

HF (Ibs/hr):-............................................................... 1.530

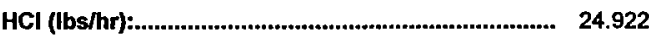

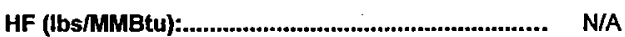

HCl (bs/MMBtu): ............................................... N/A

* Test 2 flow value is the average flow runs post 1 and post 2.

\section{Test Number:}

Pressure, Barometric(Hg"):........................

Pressure, Static $\left(\mathrm{H}_{2} \mathrm{O}^{\prime \prime}\right)$

Pressure, Stack(Hg"):.

Final Volume (liters).

Meter Temperature $(\mathrm{F})$............................

Meter Volume (dscf)....................................

Meter Calibration $(M$.

Initial Wt. (grms or mls)...............................

Final Wt. (grms or $\mathrm{m} / \mathrm{s}$ )

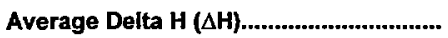

Dry Standard Flow Rate (dscfm): *.
3

29.920

$-1.10$

29.839

6983.680

7103.940

105.54

4.017

1.007

714.0

724.5

2.500

$1,682,868$
Time:

Carbon Dioxide Content(\%):....................................... 13.30

Oxygen Content(\%):................................................... $\quad 6.80$

Nitrogen Content(\%):.............................................. $\quad 79.90$

HF (mg) ............................................................ 0.028

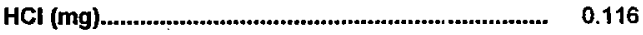

Water Vapor in Flue Gas (Bws):................................ 0.110

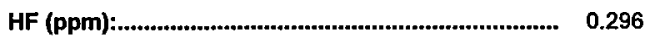

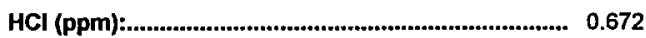

HF (lbs/hr):.............................................................. 1.552

HCI (lbs/hr):............................................................ 6.428

HF (Ibs/MMBtu):_............................................... N/A

HCI (lbs/MMBtu):................................................ N/A

* Test 3 flow value is the average flow runs post 2 and post 3.

\section{Average HCI Ibs/hr:}

Average $\mathrm{HCl}$ ppm:

Average Flow Rate (dscfm)

12.697
1.326

1683903
Average HF lbs/hr:

Average $\mathrm{HF}$ ppm: 


$\begin{array}{llll}\text { Date: } & 2 / 8 / 2006 & \text { Condition: } & \text { Normal } \\ \text { Project: } & \text { MidAmerican } & \text { Data Taken By: } & \text { CFM/MJK } \\ \text { Location: } & \text { Louisa Generating Station } & \text { Fuel Factor: } & \text { N/A } \\ \text { Source: } & \text { Unit } 1 \text { Stack } & & \end{array}$

\begin{tabular}{|c|c|c|c|}
\hline Test Number: & 1 & $11: 25-12:$ & \\
\hline Pressure, Barometric(Hg"):..................... & 29.920 & Carbon Dioxide Content(\%):............................... & 13.50 \\
\hline Pressure, Static $\left(\mathrm{H}_{2} \mathrm{O}^{\prime \prime}\right)$ :.......................... & -1.10 & 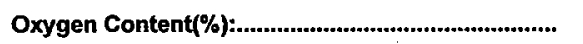 & 6.50 \\
\hline Pressure, Stack(Hg") & 29.839 & 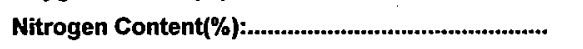 & 80.00 \\
\hline Initial Volume (liters) & 6737.29 & HBr (mg) & 0.050 \\
\hline Final Volume (liters) .................................... & 6857.49 & $\mathrm{HCl}(\mathrm{mg})$ & N/A \\
\hline 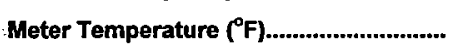 & 90.23 & Water Vapor in Flue Gas (Bws): & 0.113 \\
\hline Meter Volume (dscf) & 4.127 & $\mathrm{HBr}(\mathrm{ppm}):$ & 0.127 \\
\hline 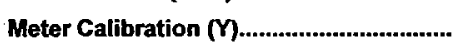 & 1.007 & $\mathrm{HCl}(\mathrm{ppm}):$ & N/A \\
\hline 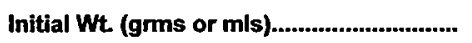 & 826.6 & HBr (lbs/hr): & 2.697 \\
\hline Final Wt. (grms or mls) & 837.8 & 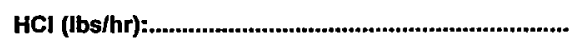 & N/A \\
\hline Average Delta $H(\Delta H) \ldots \ldots \ldots \ldots \ldots \ldots$ & 2.500 & 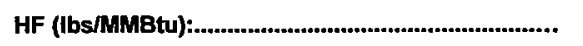 & N/A \\
\hline Dry Standard Flow Rate (dscfin): ".......... & $1,683,018$ & 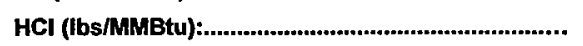 & N/A \\
\hline
\end{tabular}

- Test 1 flow value is the average flow runs pre 1 and post 1.

\begin{tabular}{|c|c|c|c|}
\hline Test Number: & 2 & 13:15-14: & 15 \\
\hline Pressure, Barometric(Hg!):...................... & 29.920 & 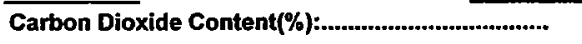 & 13.50 \\
\hline Pressure, Static $\left(\mathrm{H}_{2} \mathrm{O}^{\prime \prime}\right)$ :............................. & -1.10 & 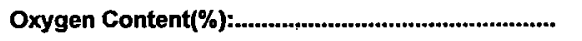 & 6.50 \\
\hline Pressure, Stack(Hg"):................................ & 29.839 & Nitrogen Content(\%):.............................................. & 80.00 \\
\hline Initial Volume (liters)..................................... & 6858.12 & HBr (mg) & 0.050 \\
\hline Final Volume (liters)...................................... & 6978.37 & 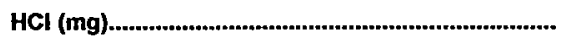 & N/A \\
\hline Meter Temperature ( ${ }^{\circ}$ F) & 96.77 & Water Vapor in Flue Gas (Bws):................. & 0.096 \\
\hline Meter Volume (dscf)..................................... & 4.080 & 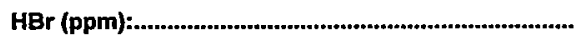 & 0.129 \\
\hline Meter Calibration (Y)................................. & 1.007 & 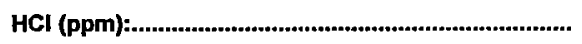 & N/A \\
\hline Initial Wt (grms or mls)............................. & 670.5 & 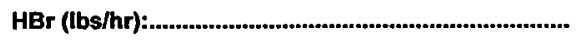 & 2.733 \\
\hline Final Wt. (grms or mls)................................ & 679.7 & 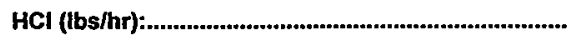 & N/A \\
\hline 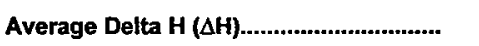 & 2.500 & 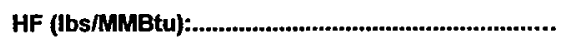 & N/A \\
\hline Dry Standard Flow Rate (dscfm): *............. & $1,685,823$ & 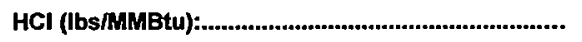 & N/A \\
\hline
\end{tabular}

* Test 2 flow value is the average flow runs post 1 and post 2 .

\section{Test Number:}

Pressure, Barometric( $\left.\mathbf{H g}^{\prime \prime)}\right)$........................

Pressure, Static $\left(\mathrm{H}_{2} \mathrm{O}^{\prime \prime}\right)$ :-

Pressure, Stack(Hg"):-...................

Initial Volume (liters)

Final Volume (liters).

Meter Temperature $\left({ }^{\circ} \mathrm{F}\right)$

Meter Volume (dscf).

Meter Calibration ( $Y$ )

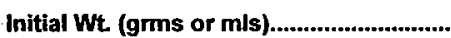

Final Wt: (grms or mls).

Average Delta $\mathbf{H}(\mathrm{AH})$

Dry Standard Flow Rate (dscfm): *

\begin{tabular}{l}
3 \\
\hline 29.920 \\
-1.10 \\
29.839 \\
6983.680 \\
7103.940 \\
105.54 \\
4.017 \\
1.007 \\
714.0 \\
724.5 \\
2.500 \\
$1,682,868$
\end{tabular}

Time:

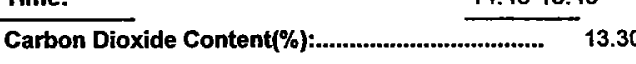

Oxygen Content(\%):.................................................. $\quad 6.80$

Nitrogen Content(\%):........................................... $\quad 79.90$

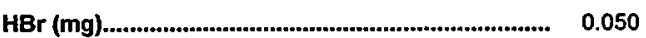

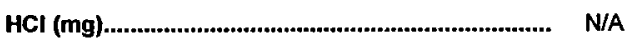

Water Vapor in Flue Gas (Bws):.............................. 0.110

HBr (ppm):......................................................................... 0.131

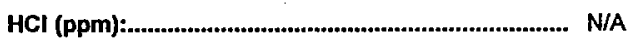

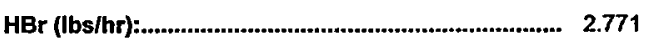

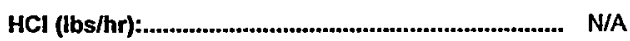

HF (Ibs/MMBtu) :............................................. N/A

HCl (Ibs/MMBtu):................................................. N/A

* Test 3 flow value is the average flow runs post 2 and post 3.

Note: $\mathrm{HBr}$ laboratory results are below the detection limit of $0.05 \mathrm{mg}$.

Average $\mathrm{HBr}$ lbs/hr: $\quad 2.733$

Average $\mathrm{HBr}$ ppm: $\quad 0.129$

Average Flow Rate (dscfm) 1683903 


$\begin{array}{lllll}\text { Date: } & 2 / 8 / 2006 & 1 & \text { Condition: } & \text { Nomal } \\ \text { Project: } & \text { MidAmerican } & & \text { Data Taken By: } & \text { CFM/MJK } \\ \text { Location: } & \text { Louisa Generating Station } & \text { Fuel Factor: } & \text { N/A } \\ \text { Source: } & \text { Unit 1 Stack } & & \end{array}$

\begin{tabular}{|c|c|c|c|}
\hline Test Number: & 1 & $11: 25-12:$ & \\
\hline Pressure, Barometric(Hg"):......................... & 29.920 & 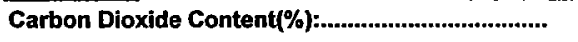 & 13.50 \\
\hline Pressure, Static $\left(\mathrm{H}_{2} \mathrm{O}^{\prime \prime}\right)$ :............................. & -1.10 & 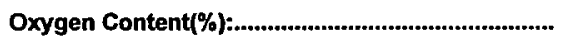 & 6.50 \\
\hline 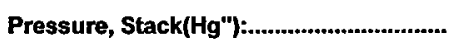 & 29.839 & 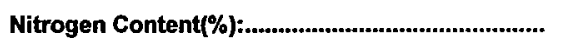 & 80.00 \\
\hline Initial Volume (liters)..................................... & 6737.29 & $B r_{2}(m g)$ & 0.050 \\
\hline Final Volume (liters)....................................... & 6857.49 & $\mathrm{Cl}_{2}(\mathrm{mg})$ & 0.117 \\
\hline 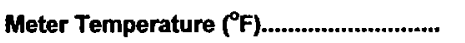 & 90.23 & 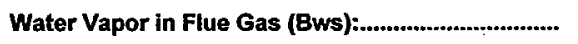 & 0.113 \\
\hline Meter Volume (dscf)....................................... & 4.127 & 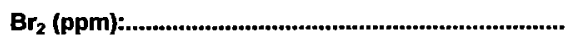 & 0.064 \\
\hline Meter Calibration (Y).................................. & 1.007 & 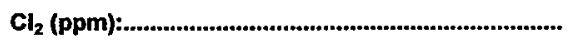 & 0.339 \\
\hline 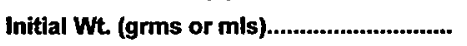 & 826.6 & $\mathrm{Br}_{2}(\mathrm{lbs} / \mathrm{hr}): \ldots$ & 2.697 \\
\hline 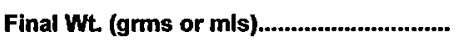 & 837.8 & 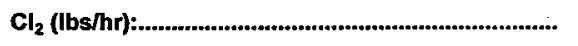 & 6.311 \\
\hline Average Delta $H(\Delta H) \ldots \ldots \ldots$ & 2.500 & $\mathrm{Br}_{2}$ (bs/MMBtu): & N/A \\
\hline Dry Standard Flow Rate (dscfm): *......... & $1,683,018$ & 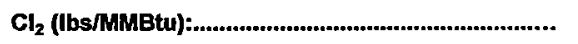 & N/A \\
\hline
\end{tabular}

* Test 1 flow value is the average flow runs pre 1 and post 1.

\begin{tabular}{|c|c|c|c|}
\hline Test Number: & 2 & 13:15-14: & \\
\hline Pressure, Barometric(Hg"):....................... & 29.920 & Carbon Dioxide Content(\%):...................................... & 13.50 \\
\hline Pressure, Static $\left(\mathrm{H}_{2} \mathrm{O}^{\prime \prime}\right)$ :.............................. & -1.10 & 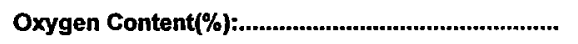 & 6.50 \\
\hline Pressure, Stack(Hg"):................................. & 29.839 & 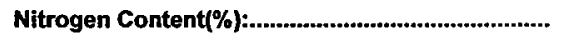 & 80.00 \\
\hline Initial Volume (liters)..................................... & 6858.12 & 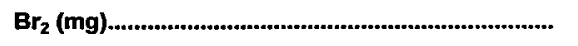 & 0.050 \\
\hline Final Volume (titers)............................... & 6978.37 & $\mathrm{Cl}_{2}$ (mg) & 0.133 \\
\hline Meter Temperature ( $\left.{ }^{\circ} F\right)$ & 96.77 & 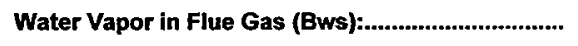 & 0.096 \\
\hline Meter Volume (dscf)................................... & 4.080 & $\mathrm{Br}_{2}(\mathrm{ppm}):$ & 0.065 \\
\hline Meter Calibration (M)................................... & 1.007 & $\mathrm{Cl}_{2}(\mathrm{ppm})$ & 0.390 \\
\hline Initial Wt. (grms or mls)............................. & 670.5 & $\mathrm{Br}_{2}(\mathrm{lbs} / \mathrm{hr}): \ldots$ & 2.733 \\
\hline 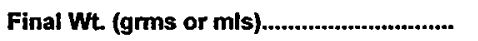 & 679.7 & $\mathrm{Cl}_{2}$ (lbs/hr): & 7.269 \\
\hline Average Delta $H(\Delta H)$ & 2.500 & 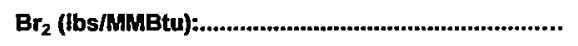 & N/A \\
\hline Dry Standard Flow Rate (dscfm): *............. & $1,685,823$ & 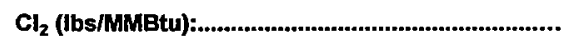 & N/A \\
\hline
\end{tabular}

- Test 2 flow value is the average flow runs post 1 and post 2.

Test Number:

Pressure, Barometric(Hg"):......................

Pressure, Static $\left(\mathrm{H}_{2} \mathrm{O}^{\prime \prime}\right)$ :

Pressure, Stack(Hg"):..............

Initial Volume (liters)

Final Volume (liters).

Meter Temperature $\left({ }^{\circ} \mathrm{F}\right)$..

Meter Volume (dscf).

Meter Calibration $(\mathrm{Y}$ ).

Initial Wt. (grms or mls)

Final Wt. (grms or mis)

Average Delta $H(\Delta H)$.

Avy Standard Flow Rate

\begin{tabular}{l}
3 \\
\hline 29.920 \\
-1.10 \\
29.839 \\
6983.680 \\
7103.940 \\
105.54 \\
4.017 \\
1.007 \\
714.0 \\
724.5 \\
2.500 \\
$1,682,868$
\end{tabular}

Time:

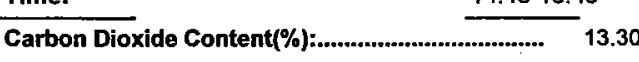

Oxygen Content(\%):.................................................... $\quad 6.80$

Nitrogen Content(\%):-.......................................... $\quad 79.90$

$\mathrm{Br}_{2}$ (mg)........................................................... 0.050

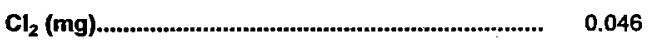

Water Vapor in Flue Gas (Bws):............................... 0.110

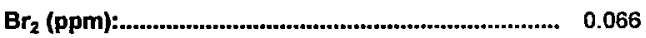

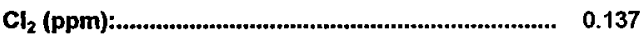

$\mathrm{Br}_{2}$ (lbs/hr):.......................................................... 2.771

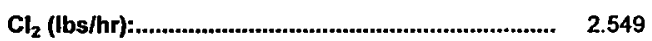

$\mathrm{Br}_{2}$ (Ibs/MMBtu):.................................................. N/A

$\mathrm{Cl}_{2}$ (Ibs/MMBtu):............................................ N/A

- Test 3 flow value is the average flow runs post 2 and post 3.

Note: $\mathrm{Br}_{2}$ Jaboratory results are below the detection limit of $0.05 \mathrm{mg}$.

Average $\mathrm{Cl}_{2}$ lbs/hr:

Average $\mathrm{Cl}_{2}$ ppm:

5.376

Average Flow Rate (dscfm)
0.289

1683903
Average $\mathrm{Br}_{2}$ lbs/hr: $\quad 2.733$

Average $\mathrm{Br}_{2}$ ppm: $\quad 0.065$ 


$\begin{array}{llll}\text { Date: } & \text { 2/9/2006 } & \text { Condition: } & \text { Normal } \\ \text { Project: } & \text { MidAmerican } & \text { Data Taken By: } & \text { CFMMJK } \\ \text { Location: } & \text { Louisa Generating Station } & \text { Fuel Factor: } & \text { N/A } \\ \text { Source: } & \text { Unit 1 Stack } & & \end{array}$

\begin{tabular}{|c|c|c|c|c|}
\hline Test Number: & 1 & Time: & \multicolumn{2}{|c|}{$12: 25-13: 25$} \\
\hline Pressure, Barometric(Hg"):...................... & 29.960 & Carbor & (.................... & 13.90 \\
\hline Pressure, Static $\left(\mathrm{H}_{2} \mathrm{O}\right.$ "): & -1.00 & Oxyge & ................ & 5.60 \\
\hline Pressure, Stack(Hg"):-................................ & 29.886 & Nitrog & $\ldots . . . . . . . . .$. & 80.50 \\
\hline Initial Volume (liters) & 7127.26 & HF (mg & (n.................. & 0.022 \\
\hline 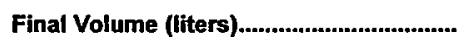 & 7247.5 & $\mathrm{HCl}(\mathrm{m}$ & (n)..................... & 0.163 \\
\hline 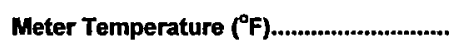 & 78.46 & Water & ...................... & 0.110 \\
\hline Meter Volume (dscf) & 4.224 & HF (pp & (n..................... & 0.221 \\
\hline 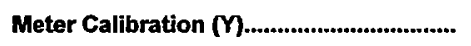 & 1.007 & $\mathrm{HCl}(\mathrm{pr}$ & ...................... & 0.898 \\
\hline 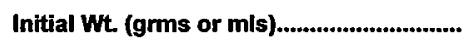 & 698.9 & HF (lbs & ................... & 1.197 \\
\hline Final Wt. (grms or mls) & 740.0 & $\mathrm{HCl}(\mathrm{lb}$ & .................. & 8.868 \\
\hline Average Delta $H(\Delta H) \ldots$ & 2.500 & HF (Ibs & ................ & NAA \\
\hline Dry Standard Flow Rate (dscfm): '........... & $1,737,321$ & $\mathrm{HCl}(\mathrm{Ib}$ & (.................... & N/A \\
\hline
\end{tabular}

- Test 1 flow value is the average flow runs pre 1 and post 1.

\begin{tabular}{|c|c|}
\hline & 2 \\
\hline Pressure, Barometric(Hg"):........................ & 29.960 \\
\hline 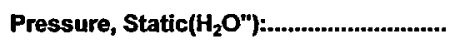 & -1.00 \\
\hline 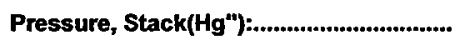 & 29.886 \\
\hline 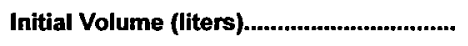 & 7252.31 \\
\hline 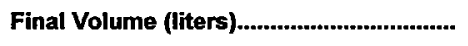 & 7372.52 \\
\hline Meter Temperature $\left({ }^{\circ} \mathrm{F}\right) \ldots \ldots \ldots \ldots \ldots$ & 74.62 \\
\hline 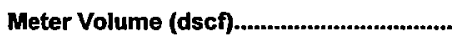 & 4.254 \\
\hline 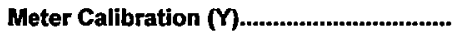 & 1.007 \\
\hline Initial Wt. (grms or mls) & 698.9 \\
\hline Final Wt (gms or mls) & 711.5 \\
\hline Average Delta $H(\Delta H)$ & 2.500 \\
\hline Dry Standard Flow Rate (dscfm): * *.............. & $1,714,553$ \\
\hline
\end{tabular}

\begin{tabular}{|c|c|c|}
\hline Time: & 14:05-15: & \\
\hline Carbon & $\ldots$ & \\
\hline Oxygen & $\ldots$ & \\
\hline Nitroge & 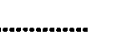 & \\
\hline HF $(\mathrm{mg}$ & ................... & \\
\hline $\mathrm{HCl}$ (mg & .......... & \\
\hline Water & $\ldots$ & \\
\hline HF (ppr & $\ldots . . . . .$. & \\
\hline $\mathrm{HCl}(\mathrm{pp}$ & 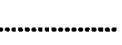 & \\
\hline HF (lbs & ............... & \\
\hline $\mathrm{HCl}(\mathrm{lbs}$ & ......... & \\
\hline HF (Ibs & $\ldots$ & \\
\hline $\mathrm{HCl}(\mathrm{lbs}$ & ....... & \\
\hline
\end{tabular}

- Test 2 flow value is the average flow runs post 1 and post 2.

\begin{tabular}{|c|c|}
\hline Test & 3 \\
\hline Pressure, Barometric(Hg"):......................... & 29.960 \\
\hline Pressure, Static $\left(\mathrm{H}_{2} \mathrm{O}^{\prime \prime}\right)$ & -1.00 \\
\hline Pressure, Stack(Hg"):................................. & 29.886 \\
\hline Initial Volume (liters) & 7375.450 \\
\hline Final Volume (liters) ...................................... & 7495.640 \\
\hline 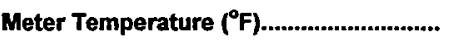 & 81.23 \\
\hline Meter Volume (dscf) & 4.201 \\
\hline 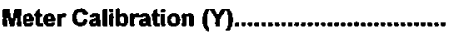 & 1.007 \\
\hline 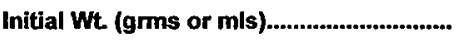 & 715.6 \\
\hline Final Wt. (grms or mls) & 725.2 \\
\hline Average Delta $H(\Delta H) \ldots$ & 2.500 \\
\hline Dry Standard Flow Rate (dscfm): * ................. & $1,769,099$ \\
\hline
\end{tabular}

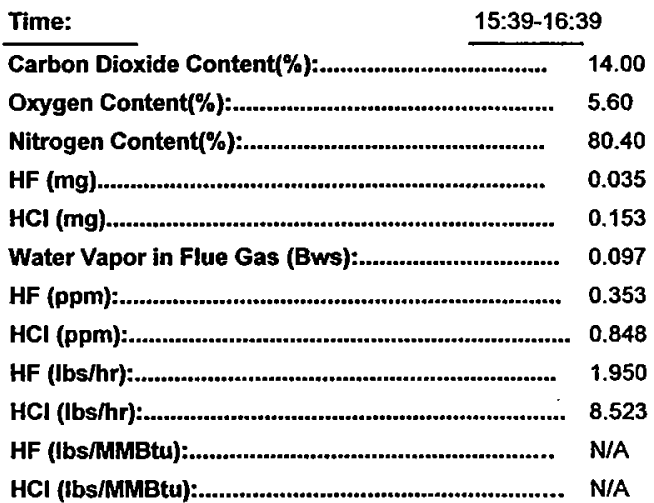

- Test 3 flow value is the average flow runs post 2 and post 3.

\begin{tabular}{|c|c|c|c|}
\hline Average HCl lbs/hr: & 7.912 & Average HF lbs/hr: & $\% 1.440$ \\
\hline Average $\mathrm{HCl}$ ppm: & 0.799 & Average HF ppm: & 0.265 \\
\hline Average Flow Rate (dscfm) & 17403 & & \\
\hline
\end{tabular}




$\begin{array}{llll}\text { Date: } & 2 / 9 / 2006 & \text { Condition: } & \text { Normal } \\ \text { Project: } & \text { MidAmerican } & \text { Data Taken By: } & \text { CFM/MJK } \\ \text { Location: } & \text { Louisa Generating Station } & \text { Fuel Factor: } & \text { N/A } \\ \text { Source: } & \text { Unit } 1 \text { Stack } & & \end{array}$

\begin{tabular}{|c|c|c|c|}
\hline Test Number: & 1 & $12: 25-13: 2$ & 25 \\
\hline Pressure, Barometric(Hg"):......................... & 29.960 & 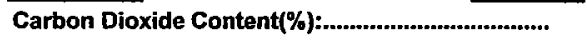 & 13.90 \\
\hline Pressure, Static $\left(\mathrm{H}_{2} \mathrm{O}^{\prime \prime}\right)$ :............................ & -1.00 & 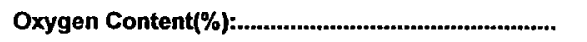 & 5.60 \\
\hline Pressure, Stack(Hg"):............................... & 29.886 & 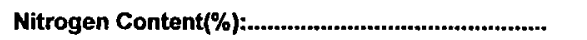 & 80.50 \\
\hline Initial Volume (liters) & 7127.26 & HBr (mg) & 0.136 \\
\hline Final Volume (liters)...................................... & 7247.5 & 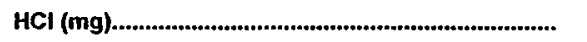 & N/A \\
\hline Meter Temperature ('F)............................ & 78.46 & 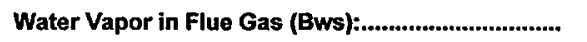 & 0.110 \\
\hline Meter Volume (dscf).................................... & 4.224 & HBr (ppm): & 0.338 \\
\hline Meter Calibration (Y).................................... & 1.007 & 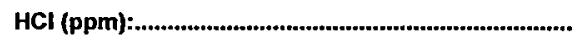 & N/A \\
\hline 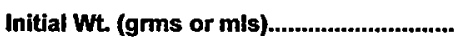 & 698.9 & HBr (lbs/hr): & 7.399 \\
\hline Final Wt. (grms or mls) ............................... & 710.0 & HCl (lbs/hr): & N/A \\
\hline 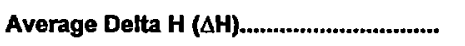 & 2.500 & 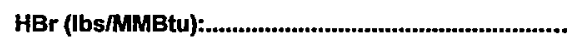 & N/A \\
\hline Dry Standard Flow Rate (dscfm): “......... & $1,737,321$ & 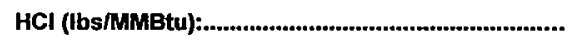 & N/A \\
\hline
\end{tabular}

* Test 1 flow value is the average fiow runs pre 1 and post 1.

\section{Test Number:}

Pressure, Barometric $\left(\mathrm{Hg}^{\prime \prime}\right)$ :......................

Pressure, Static $\left(\mathrm{H}_{2} \mathrm{O}^{\prime \prime}\right)$ :

Pressure, Stack(Hg"):

Initial Volume (liters)

Final Volume (liters).

Meter Temperature ( $\mathbf{F}$ )

Meter Volume (dscf).

Meter Calibration $(\mathrm{Y})$.

Initial Wt. (grms or mis).

Final Wt. (grms or mls)

Average Delta $H(\Delta H)$.

Dry Standard Flow Rate (dscfm):

\begin{tabular}{l}
2 \\
\hline 29.960 \\
-1.00 \\
29.886 \\
7252.31 \\
7372.52 \\
74.62 \\
4.254 \\
1.007 \\
698.9 \\
711.5 \\
2.500 \\
$1,714,553$
\end{tabular}

Time:

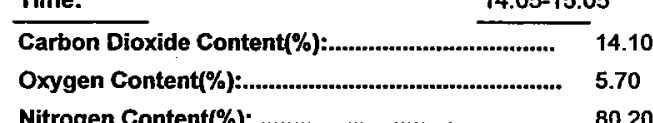

Nitrogen Content(\%):

HBr (mg).

80.20

HCI (mg). 0.176

Water Vapor in Flue Gas (Bws):.............................. 0.123

HBr (ppm):................................................................ 0.434

HCl (ppm):............................................................. N/A

HBr (lbs/hr):....................................................... 9.384

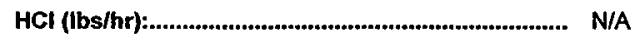

HBr (lbs/MMBtu):.............................................. N/A

HCl (Ibs/MMBtu):............................................... N/A

* Test 2 flow value is the average flow runs post 1 and post 2 .

Test Number:

Pressure, Barometric(Hg"):......................

Pressure, Static $\left(\mathrm{H}_{2} \mathrm{O}^{\mathrm{m}}\right)$ :

Pressure, Stack(Hg"):

Initial Volume (liters)

Final Volume (liters).

Meter Temperature $\left({ }^{\circ} \mathbf{F}\right.$ ).

Meter Volume (dscf).

Meter Calibration (Y).

Initial Wt. (grms or m/s)

Final Wt. (grms or mls).

Average Delta $H(\Delta H)$.

Dry Standard Flow Rate (dscfm):
3

29.960

$-1.00$

29.886

7375.450

7495.640

81.23

4.201

1.007

715.6

725.2

2.500

1,769,099
Time:

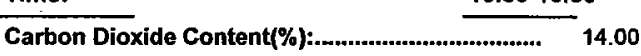

Oxygen Content $(\%)$ :.............................................. $\quad 5.60$

Nitrogen Content(\%):........................................ 80.40

HBr (mg) .............................................................. 0.147

HCl (mg)..................................................... N/A

Water Vapor in Flue Gas (Bws):........................... 0.097

HBr (ppm):................................................................ 0.367

HCI (ppm):........................................................... N/A

HBr (lbs/hr):............................................................ 8.189

HCl (lbs/hr):................................................. N/A

HBr (tbs/MMBtu):........................................... N/A

HCl (Ibs/MMBtu):.............................................. N/A

* Test 3 flow value is the average flow runs post 2 and post 3 .

\begin{tabular}{ll}
\hline Average HBr lbs/hr: & 8.324 \\
Average HBr ppm: & 0.380 \\
Average Flow Rate (dsctm) & 1740324
\end{tabular}




$\begin{array}{llll}\text { Date: } & \text { 2/9/2006 } & \text { Condition: } & \text { Normal } \\ \text { Project: } & \text { MidAmerican } & \text { Data Taken By: } & \text { CFM/MJK } \\ \text { Location: } & \text { Louisa Generating Station } & \text { Fuel Factor: } & \text { N/A } \\ \text { Source: } & \text { Unit 1 Stack } & & \end{array}$

Test Number:

Pressure, Barometric(Hg"):........................

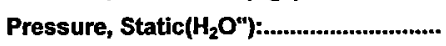

Pressure, Stack(Hg"):..................................

Initial Volume (liters)...................................

Final Volume (liters)..

Meter Temperature ('F)............................

Meter Volume (dscf)...................................

Meter Calibration ( $M$.

Initial Wt. (grms or mls)...

Final Wt. (grms or mls)................................

Average Delta $\mathbf{H}(\mathbf{A H})$.

Dry Standard Flow Rate (dscfm): *..........
1

29.960

$-1.00$

29.886

7127.26

7247.5

78.46

4.224

1.007

698.9

710.0

2.500

$1,737,321$
Time: 12:25-13:25

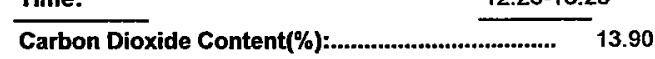

Oxygen Content(\%):................................................... $\quad 5.60$

Nitrogen Content(\%):............................................ $\quad \mathbf{8 0 . 5 0}$

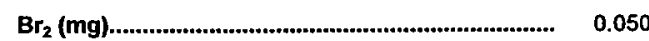

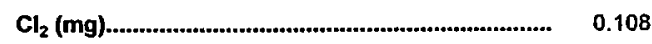

Water Vapor in Flue Gas (Bws):.............................. 0.110

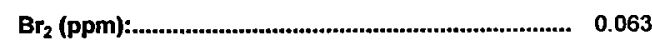

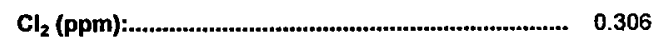

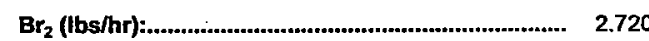

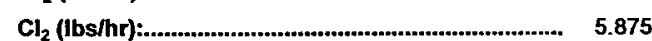

$\mathrm{Br}_{2}$ (lbs/MMBtu):............................................ N/A

$\mathrm{Cl}_{2}$ (bs/MMBtu):............................................... N/A

* Test 1 flow value is the average flow runs pre 1 and post 1.

Test Number:

Pressure, Barometric( $\mathrm{Hg}$ "):........................

Pressure, Static( $\left.\mathrm{H}_{2} \mathrm{O}^{\prime \prime}\right)$ :

Pressure, Stack(Hg"):

Initial Volume (liters)..

Final Volume (liters).

Meter Temperature $\left({ }^{\circ} \mathrm{F}\right)$.

Meter Volume (dscf).....................................

Meter Calibration (M)

Initial Wt. (grms or mls)..............................

Final Wt (grms or mls).

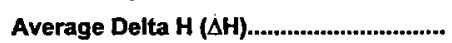

Dry Standard Flow Rate (dscfm): *.

$\frac{2}{29.960}$
-1.00
29.886
7252.31
7372.52
74.62
4.254
1.007
698.9
711.5
2.500
$1,714,553$

Time

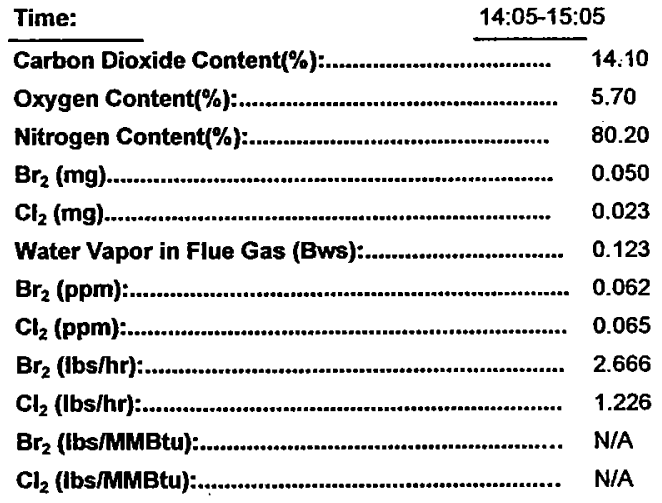

- Test 2 flow value is the average flow runs post 1 and post 2.

\begin{tabular}{|c|c|c|c|}
\hline Test Number: & 3 & 15:39-16: & \\
\hline Pressure, Barometric(Hg"):....................... & 29.960 & 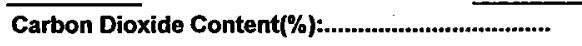 & 14.00 \\
\hline 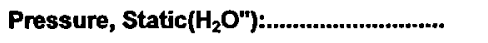 & -1.00 & Oxygen Content(\%): & 5.60 \\
\hline Pressure, Stack(Hg"):_................................. & 29.886 & Nitrogen Content(\%): & 80.40 \\
\hline 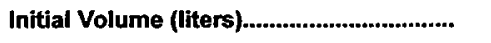 & 7375.450 & $\mathrm{Br}_{\mathbf{2}}(\mathrm{mg})$ & 0.050 \\
\hline Final Volume (liters)..................................... & 7495.640 & $\mathrm{Cl}_{2}$ (mg) & 0.041 \\
\hline 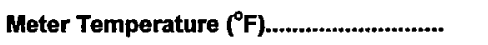 & 81.23 & 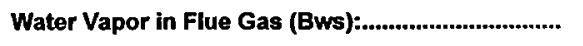 & 0.097 \\
\hline Meter Volume (dscf)..................................... & 4.201 & $\mathrm{Br}_{2}(\mathrm{ppm}):$ & 0.063 \\
\hline 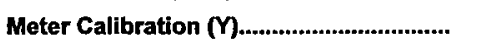 & 1.007 & $\mathrm{Cl}_{2}$ (ppm): & 0.117 \\
\hline 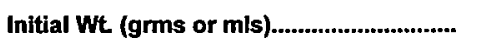 & 715.6 & $\mathrm{Br}_{2}$ (lbs/hr): & 2.785 \\
\hline Final Wt. (grms or mls)................................. & 725.2 & $\mathrm{Cl}_{2}$ (lbs/hr): & 2.284 \\
\hline Average Delta $H(\Delta H) \ldots$ & 2.500 & $\mathrm{Br}_{2}$ (lbs/MMBtu) & N/A \\
\hline Dry Standard Flow Rate (dscfm): *.............. & $1,769,099$ & $\mathrm{Cl}_{2}$ (lbs/MMBtu): & N/A \\
\hline \multicolumn{4}{|c|}{ Note: $\mathrm{Br}_{2}$ laboratory results are below the detection limit of $0.05 \mathrm{mg}$. } \\
\hline Average $\mathrm{Cl}_{2} \mathrm{lbs} / \mathrm{hr}$ : & 3.129 & Average $\mathrm{Br}_{2} \mathrm{lbs} / \mathrm{hr}$ : & 2.724 \\
\hline Average $\mathrm{Cl}_{2}$ ppm: & 0.163 & Average $\mathrm{Br}_{2} \mathrm{ppm}$ : & 0.063 \\
\hline Average Flow Rate (dscfm) & 1740324 & & \\
\hline
\end{tabular}


METHOD 2 VOLUMETRIC FLOW DATA

$\begin{array}{ll}\text { Project No: } & \text { M22E1180 } \\ \text { Company: } & \text { MidAmerican } \\ \text { Plant: } & \text { Louisa Generating Station } \\ \text { Source: } & \text { Unit 1 Stack } \\ \text { Pitot ID: } & 789 \mathrm{~A} \\ \text { Pitot Coefficient: } & 0.840\end{array}$

Pitot Coefficient: $\quad 0.840$

\section{Test Parameters}

$P_{\text {bar }}$ - Barometric pressure, inches $\mathrm{Hg}$

$\mathrm{P}_{\mathrm{g}}$ - Stack Pressure, inches of $\mathrm{H}_{2} \mathrm{O}$

$P_{s}$ - Absolute stack pressure, inches $\mathrm{Hg}$

$t_{s}$ - Average stack temperature, ${ }^{\circ} \mathrm{F}$

$\% \mathrm{CO}_{2}$

$\% \mathrm{O}_{2}$

$\% \mathrm{~N}_{2}$

Md - dry basis $\mathrm{lb} / \mathrm{lb}$ mole

Ms - wet basis lb/lb mole

Stack Diameter, Feet

Cross Sectional Area of Stack, $\mathrm{Ft}^{2}$

$\begin{array}{ll}\text { Source Condition: } & \text { Normal } \\ \text { Run No.: } & \text { Pre } 1 \\ \text { Date: } & 2 / 8 / 2006 \\ \text { Start Time: } & 10: 45 \\ \text { End Time: } & 11: 05 \\ \text { RM Testers: } & \text { CFM/MJK }\end{array}$

Moisture Determination

Meter Calibration:

0.998

Initial Meter Volume:

237.925

Final Meter Volume:

242.170

Meter Temperature:

90.23

297.7

13.5

6.5

80.0

30.42

29.00

32.15

811.81
4.093

0.528

2.50

826.600

837.800

$\begin{array}{ll}\text { Condensate Initial Vol: } & 0.000 \\ \text { Condensate Final Vol: } & 0.000\end{array}$

Condensate Final Vol: $\quad 0.000$

\begin{tabular}{|c|c|c|c|c|c|c|c|c|c|c|}
\hline Port Point & $\underset{\text { (in. } \mathrm{H}_{2} \mathrm{O} \text { ) }}{\Delta P}$ & $\underset{\Delta p}{\text { Sqrt. }}$ & $\underset{(F)}{T e m p}$ & $\begin{array}{c}\text { Velocity } \\
\text { (V) }\end{array}$ & Port & Point & $\begin{array}{c}\Delta P \\
\left.\text { (in. } H_{2} O\right)\end{array}$ & $\underset{\Delta P}{\text { Sqrt. }}$ & $\underset{(T F)}{T e m p}$ & $\begin{array}{c}\text { Velocity } \\
\text { (V) }\end{array}$ \\
\hline A 02 & 0.70 & 0.8367 & 298 & 56.23 & & 02 & 0.77 & 0.8775 & 298 & 58.97 \\
\hline A 04 & 0.52 & 0.7211 & 296 & 48.40 & & 04 & 0.61 & 0.7810 & 297 & 52.45 \\
\hline
\end{tabular}

$\begin{array}{rllll}\text { B 01 } & 0.76 & 0.8718 & 298 & 58.59 \\ \text { B 02 } & 0.78 & 0.8832 & 298 & 59.35 \\ \text { B 03 } & 0.78 & 0.8832 & 296 & 59.28 \\ \text { B 04 } & 0.61 & 0.7810 & 296 & 52.42\end{array}$

$\begin{array}{llll}\text { D 01 } & 0.80 & 0.8944 & 298 \\ \text { D 02 } & 0.78 & 0.8832 & 299 \\ \text { D 03 } & 0.79 & 0.8888 & 299 \\ \text { D 04 } & 0.63 & 0.7937 & 299\end{array}$

60.11

59.39

59.77

53.38

\begin{tabular}{ll}
\hline Method 2 Results & \\
Average $\Delta P$ & 0.7181 \\
Average Sqrt $\Delta P$ & 0.8460 \\
Average Velocity Vs (ft/sec) & 56.831 \\
No WAF Applied to this Test & \\
Q - ACFM & $2,768,157$ \\
Qsd - DSCFM & $1,704,483$ \\
Qs - SCFM & $1,923,795$ \\
Qs - SCFH & $115,427,720$
\end{tabular}




\section{METHOD 2 VOLUMETRIC FLOW DATA}

$\begin{array}{ll}\text { Project No: } & \text { M22E1180 } \\ \text { Company: } & \text { MidAmerican } \\ \text { Plant: } & \text { Louisa Generating Station } \\ \text { Source: } & \text { Unit 1 Stack } \\ \text { Pitot ID: } & 789 \mathrm{~A} \\ \text { Pitot Coefficient: } & 0.840\end{array}$

Test Parameters

$\mathrm{P}_{\text {bar }}$ - Barometric pressure, inches $\mathrm{Hg}$

$P_{g}$ - Stack Pressure, inches of $\mathrm{H}_{2} \mathrm{O}$

$P_{\mathbf{s}}$ - Absolute stack pressure, inches $\mathrm{Hg}$

$\mathrm{t}_{\mathrm{s}}$ - Average stack temperature, ${ }^{\text {UF }}$

$\% \mathrm{CO}_{2}$

$\% \mathrm{O}_{2}$

$\% \mathrm{~N}_{2}$

Md - dry basis lb/lb mole

Ms - wet basis $\mathrm{lb} / \mathrm{lb}$ mole

Stack Diameter, Feet

Cross Sectional Area of Stack, $\mathbf{F t}^{2}$

29.92

$-1.10$

29.84

296.6

13.1

6.7

80.2

30.36

28.95

32.15

811.81

$\begin{array}{ll}\text { Source Condition: } & \text { Normal } \\ \text { Run No.: } & \text { Post 1/Pre 2 } \\ \text { Date: } & 2 / 8 / 2006 \\ \text { Start Time: } & 12: 44 \\ \text { End Time: } & 12: 59 \\ \text { RM Testers: } & \text { CFM/MJK }\end{array}$

Moisture Determination

Meter Calibration:

0.998

Initial Meter Volume:

237.925

Final Meter Volume:

242.170

Meter Temperature:

Meter Volume Vm(std):

90.23

4.093

Meter Volume Vw(std):

0.528

Delta $\mathrm{H}$ :

2.50

Train Initial Wt:

826.600

Train Final Wt:

837.800

Condensate Initial Vol:

0.000

Condensate Final Vol:

0.000

Bws - Moisture content fraction $\quad 0.114$

\begin{tabular}{|c|c|c|c|c|c|c|c|c|c|}
\hline Port Point & $\begin{array}{c}\Delta P \\
\text { (in. } H_{2} \mathrm{O} \text { ) }\end{array}$ & $\underset{\Delta P}{\text { Sqrt. }}$ & $\underset{(\mathrm{T})}{\operatorname{Temp}}$ & $\begin{array}{c}\text { Velocity } \\
\text { (V) }\end{array}$ & Port Point & $\begin{array}{c}\Delta P \\
\text { (in. } H_{2} \mathrm{O} \text { ) }\end{array}$ & $\underset{\Delta \mathbf{P}}{\text { Sqrt. }}$ & $\underset{(F F)}{\text { Temp }}$ & $\begin{array}{c}\text { Velocity } \\
\text { (V) }\end{array}$ \\
\hline A 01 & 0.80 & 0.8944 & 297 & 60.12 & C 01 & 0.77 & 0.8775 & 297 & 58.98 \\
\hline A 02 & 0.71 & 0.8426 & 297 & 56.64 & C 02 & 0.72 & 0.8485 & 297 & 57.04 \\
\hline A 04 & 0.51 & 0.7141 & 297 & 48.00 & C 04 & 0.58 & 0.7616 & 296 & 51.16 \\
\hline
\end{tabular}

$\begin{array}{lllll}\text { B 01 } & 0.79 & 0.8888 & 297 & 59.75 \\ \text { B 02 } & 0.71 & 0.8426 & 297 & 56.64 \\ \text { B 03 } & 0.69 & 0.8307 & 296 & 55.80 \\ \text { B 04 } & 0.55 & 0.7416 & 296 & 49.82\end{array}$

$\begin{array}{lllll}\text { D 01 } & 0.72 & 0.8485 & 298 & 57.07 \\ \text { D 02 } & 0.67 & 0.8185 & 298 & 55.06 \\ \text { D 03 } & 0.65 & 0.8062 & 295 & 54.12 \\ \text { D 04 } & 0.58 & 0.7616 & 295 & 51.12\end{array}$

\begin{tabular}{ll}
\hline Method 2 Results & \\
Average $\Delta P$ & 0.6806 \\
Average Sqrt $\Delta P$ & 0.8234 \\
Average Velocity Vs (ft/sec) & 55.322 \\
No WAF Applied to this Test & \\
Q - ACFM & $2,694,652$ \\
Qsd - DSCFM & $1,661,552$ \\
Qs - SCFM & $1,875,341$ \\
Qs - SCFH & $112,520,462$
\end{tabular}


METHOD 2 VOLUMETRIC FLOW DATA

$\begin{array}{ll}\text { Project No: } & \text { M22E1180 } \\ \text { Company: } & \text { MidAmerican } \\ \text { Plant: } & \text { Louisa Generating Station } \\ \text { Source: } & \text { Unit 1 Stack } \\ \text { Pitot ID: } & 789 \mathrm{~A} \\ \text { Pitot Coefficient: } & 0.84\end{array}$

Test Parameters

$P_{\text {bar }}$ - Barometric pressure, inches $\mathrm{Hg}$

$P_{g}$ - Stack Pressure, inches of $\mathrm{H}_{2} \mathrm{O}$

$P_{s}$ - Absolute stack pressure, inches $\mathrm{Hg}$

$t_{s}$ - Average stack temperature, ${ }^{\text {U }} \mathrm{F}$

$\% \mathrm{CO}_{2}$

$\% \mathrm{O}_{2}$

$\% \mathrm{~N}_{2}$

Md - dry basis lb/lb mole

Ms - wet basis $\mathrm{lb} / \mathrm{lb}$ mole

Stack Diameter, Feet

Cross Sectional Area of Stack, $\mathrm{Ft}^{2}$

29.92

$-1.10$

29.84

298.3

13.5

6.5

80.0

30.42

29.19

32.15

811.81

$\begin{array}{ll}\text { Source Condition: } & \text { Normal } \\ \text { Run No.: } & \text { Post 2/Pre 3 } \\ \text { Date: } & 2 / 8 / 2006 \\ \text { Start Time: } & 14: 24 \\ \text { End Time: } & 14: 35 \\ \text { RM Testers: } & \text { CFM/MJK }\end{array}$

Moisture Determination

Meter Calibration:

0.998

Initial Meter Volume:

242.192

Final Meter Volume:

246.439

Meter Temperature:

96.77

Meter Volume Vm(std):

4.046

Meter Volume Vw(std):

0.443

Delta H:

2.50

Train Initial Wt:

670.500

Train Final Wt:

679.900

Condensate Initial Vol:

0.000

Condensate Final Vol:

0.000

Bws - Moisture content fraction $\quad 0.099$

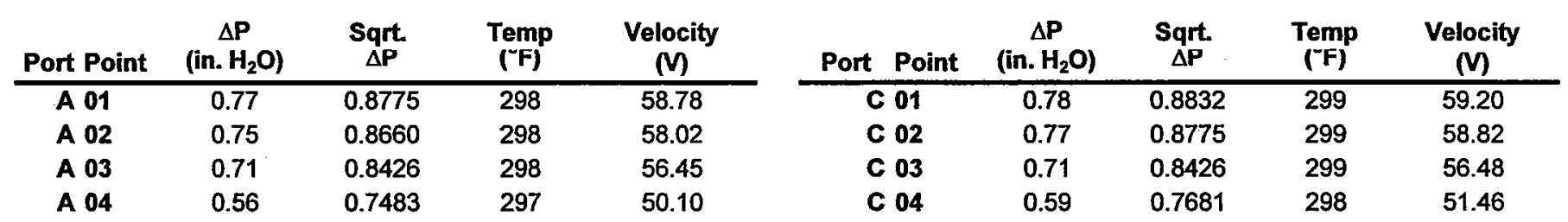

$\begin{array}{lllll}\text { B 01 } & 0.79 & 0.8888 & 298 & 59.54 \\ \text { B 02 } & 0.78 & 0.8832 & 298 & 59.16 \\ \text { B 03 } & 0.70 & 0.8367 & 299 & 56.09 \\ \text { B 04 } & 0.60 & 0.7746 & 298 & 51.89\end{array}$

Method 2 Results

Average $\triangle P$

Average Sqrt $\Delta P$

Average Velocity Vs (ft/sec)

No WAF Applied to this Test

Q - ACFM

Qsd - DSCFM

Qs - SCFM

Qs - SCFH
0.7038

0.8377

56.115

$2,733,286$

$1,710,094$

$1,897,995$

$113,879,726$

$\begin{array}{lllll}\text { D 01 } & 0.74 & 0.8602 & 298 & 57.63 \\ \text { D 02 } & 0.70 & 0.8367 & 299 & 56.09 \\ \text { D 03 } & 0.72 & 0.8485 & 299 & 56.88 \\ \text { D 04 } & 0.59 & 0.7681 & 298 & 51.46\end{array}$




\section{METHOD 2 VOLUMETRIC FLOW DATA}

$\begin{array}{ll}\text { Project No: } & \text { M22E1180 } \\ \text { Company: } & \text { MidAmerican } \\ \text { Plant: } & \text { Louisa Generating Station } \\ \text { Source: } & \text { Unit 1 Stack } \\ \text { Pitot ID: } & 789 \mathrm{~A} \\ \text { Pitot Coefficient: } & 0.84\end{array}$

Test Parameters

$P_{\text {bar }}$ - Barometric pressure, inches $\mathrm{Hg}$

$\mathrm{P}_{\mathrm{g}}$ - Stack Pressure, inches of $\mathrm{H}_{2} \mathrm{O}$

$P_{s}$ - Absolute stack pressure, inches $\mathrm{Hg}$

$t_{s}$ - Average stack temperature, ${ }^{~} \mathrm{~F}$

$\% \mathrm{CO}_{2}$

$\% \mathrm{O}_{2}$

$\% \mathrm{~N}_{2}$

Md - dry basis lb/lb mole

Ms - wet basis lb/b mole

Stack Diameter, Feet

Cross Sectional Area of Stack, $\mathrm{Ft}^{2}$

29.92

$-1.10$

29.84

296.1

13.3

6.8

79.9

30.40

29.02

32.15

811.81

$\begin{array}{ll}\text { Source Condition: } & \text { Normal } \\ \text { Run No.: } & \text { Post } 3 \\ \text { Date: } & 2 / 8 / 2006 \\ \text { Start Time: } & 15: 45 \\ \text { End Time: } & 15: 58 \\ \text { RM Testers: } & \text { CFM/MJK }\end{array}$

Moisture Determination

Meter Calibration:

Initial Meter Volume:

Final Meter Volume:

Meter Temperature:

Meter Volume Vm(std):

Meter Volume Vw(std):

CFM/MJK
Delta $\mathrm{H}$ :

Train Initial Wt:

Train Final Wt:

Condensate Initial Vol:

Condensate Final Vol:

Bws - Moisture content fraction
0.998

246.626

250.873

105.54

3.984

0.495

2.50

714.000

724.500

0.000

0.000

0.111

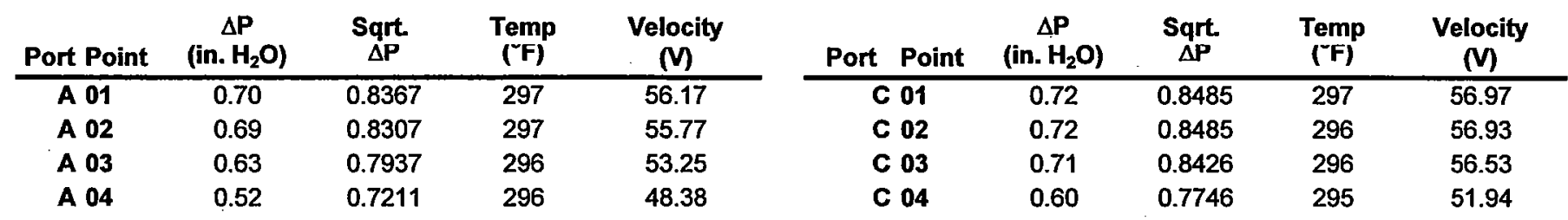

$\begin{array}{llllllllll}\text { B 01 } & 0.71 & 0.8426 & 297 & 56.57 & \text { D 01 } & 0.69 & 0.8307 & 296 & 55.73 \\ \text { B 02 } & 0.72 & 0.8485 & 296 & 56.93 & \text { D 02 } & 0.70 & 0.8367 & 296 & 56.14 \\ \text { B 03 } & 0.74 & 0.8602 & 296 & 57.72 & \text { D 03 } & 0.69 & 0.8307 & 296 & 55.73 \\ \text { B 04 } & 0.57 & 0.7550 & 296 & 50.66 & \text { D 04 } & 0.63 & 0.7937 & 295 & 53.22\end{array}$

\begin{tabular}{ll}
\hline Method 2 Results & \\
Average $\Delta P$ & 0.6713 \\
Average Sqrt $\Delta P$ & 0.8184 \\
Average Velocity Vs (ft/sec) & 54.903 \\
No WAF Applied to this Test & \\
Q - ACFM & $2,674,237$ \\
Qsd - DSCFM & $1,655,642$ \\
Qs - SCFM & $1,862,364$ \\
Qs - SCFH & $111,741,838$
\end{tabular}




$\begin{array}{ll}\text { Project No: } & \text { M22E1180 } \\ \text { Company: } & \text { MidAmerican } \\ \text { Plant: } & \text { Louisa Generating Station } \\ \text { Source: } & \text { Unit } 1 \text { Stack } \\ \text { Pitot ID: } & 789 \mathrm{~A} \\ \text { Pitot Coefficient: } & 0.840\end{array}$

\section{Test Parameters}

$P_{\text {bar }}$ - Barometric pressure, inches $\mathrm{Hg}$

$P_{g}$ - Stack Pressure, inches of $\mathrm{H}_{2} \mathrm{O}$

$P_{\mathrm{s}}$ - Absolute stack pressure, inches $\mathrm{Hg}$

$\mathrm{t}_{\mathrm{s}}$ - Average stack temperature, ${ }^{\circ} \mathrm{F}$

$\% \mathrm{CO}_{2}$

$\% \mathrm{O}_{2}$

$\% \mathrm{~N}_{2}$

Md - dry basis lb/lb mole

Ms - wet basis $\mathrm{lb} / \mathrm{lb}$ mole

Stack Diameter, Feet

Cross Sectional Area of Stack, Ft $^{2}$

29.96

$-1.00$

29.89

304.1

13.9

5.6

80.5

30.45

29.07

32.15

811.81

$\begin{array}{ll}\text { Source Condition: } & \text { Normal } \\ \text { Run No.: } & \text { Pre } 1 \\ \text { Date: } & 2 / 9 / 2006 \\ \text { Start Time: } & 11: 46 \\ \text { End Time: } & 12: 05 \\ \text { RM Testers: } & \text { CFM/MJK }\end{array}$

Moisture Determination

Meter Calibration:

Initial Meter Volume:

Final Meter Volume:

Meter Temperature:

Meter Volume Vm(std):

Meter Volume Vw(std):

Delta H:

Train Initial Wt:

Train Final Wt:

Condensate Initial Vol:

Condensate Final Vol:

Bws - Moisture content fraction
0.998

251.697

255.943

78.46

4.189

0.523

2.50

698.900

710.000

0.000

0.000

0.111

\begin{tabular}{|c|c|c|c|c|c|c|c|c|c|}
\hline Port Point & $\underset{\text { (in. } \mathrm{H}_{2} \mathrm{O} \text { ) }}{\Delta P}$ & $\underset{\Delta \mathbf{P}}{\text { Sqrt. }}$ & $\underset{(\sim F)}{\text { Temp }}$ & $\begin{array}{c}\text { Velocity } \\
\text { (V) }\end{array}$ & Port Point & $\begin{array}{c}\Delta P \\
\text { (in. } \mathrm{H}_{2} \mathrm{O} \text { ) }\end{array}$ & $\underset{\Delta \mathbf{P}}{\text { Sqrt. }}$ & $\underset{(-F)}{\text { Temp }}$ & $\begin{array}{c}\text { Velocity } \\
\text { (V) }\end{array}$ \\
\hline A 01 & 0.84 & 0.9165 & 304 & 61.72 & C 01 & 0.84 & 0.9165 & 304 & 61.72 \\
\hline A 02 & 0.86 & 0.9274 & 304 & 62.45 & C 02 & 0.83 & 0.9110 & 305 & 61.39 \\
\hline A 04 & 0.65 & 0.8062 & 303 & 54.26 & C 04 & 0.63 & 0.7937 & 303 & 53.42 \\
\hline
\end{tabular}

$\begin{array}{lllll}\text { B 01 } & 0.84 & 0.9165 & 304 & 61.72 \\ \text { B 02 } & 0.83 & 0.9110 & 304 & 61.35 \\ \text { B 03 } & 0.80 & 0.8944 & 304 & 60.24 \\ \text { B 04 } & 0.66 & 0.8124 & 304 & 54.71\end{array}$

\section{Method 2 Results}

Average $\Delta P$

Average Sqrt $\Delta P$

Average Velocity Vs (ft/sec)

No WAF Applied to this Test

$Q$ - ACFM

Qsd - DSCFM

Qs - SCFM

Qs - SCFH
0.7856

0.8852

59.604

$2,903,188$

$1,781,392$

$2,003,816$

$120,228,938$

$\begin{array}{lllll}\text { D 01 } & 0.86 & 0.9274 & 304 & 62.45 \\ \text { D 02 } & 0.87 & 0.9327 & 305 & 62.86 \\ \text { D 03 } & 0.83 & 0.9110 & 305 & 61.39 \\ \text { D 04 } & 0.69 & 0.8307 & 305 & 55.98\end{array}$




$\begin{array}{ll}\text { Project No: } & \text { M22E1180 } \\ \text { Company: } & \text { MidAmerican } \\ \text { Plant: } & \text { Louisa Generating Station } \\ \text { Source: } & \text { Unit 1 Stack } \\ \text { Pitot ID: } & 789 \mathrm{~A} \\ \text { Pitot Coefficient: } & 0.840\end{array}$

\begin{tabular}{ll}
\hline Test Parameters & \\
$\mathrm{P}_{\text {bar }}$ - Barometric pressure, inches $\mathrm{Hg}$ & 29.96 \\
$\mathrm{P}_{\mathrm{g}}$ - Stack Pressure, inches of $\mathrm{H}_{2} \mathrm{O}$ & -1.00 \\
$\mathrm{P}_{\mathrm{s}}$ - Absolute stack pressure, inches $\mathrm{Hg}$ & 29.89 \\
$\mathrm{t}_{\mathrm{s}}$ - Average stack temperature, ${ }^{\circ} \mathrm{F}$ & 303.6 \\
$\% \mathrm{CO}_{2}$ & 13.4 \\
$\% \mathrm{O}_{2}$ & 6.2 \\
$\% \mathrm{~N}_{2}$ & 80.4 \\
$\mathrm{Md}$ - dry basis Ib/lb mole & 30.39 \\
$\mathrm{Ms}$ - wet basis lb/lb mole & 29.02 \\
Stack Diameter, Feet & 32.15 \\
Cross Sectional Area of Stack, $\mathrm{Ft}^{2}$ & 811.81
\end{tabular}

$\begin{array}{ll}\text { Source Condition: } & \text { Normal } \\ \text { Run No.: } & \text { Post 1/Pre 2 } \\ \text { Date: } & 2 / 9 / 2006 \\ \text { Start Time: } & 12: 38 \\ \text { End Time: } & 13: 55 \\ \text { RM Testers: } & \text { CFM/MJK }\end{array}$

\begin{tabular}{|c|c|c|c|c|c|c|c|c|c|c|}
\hline Port Point & $\begin{array}{c}\Delta P \\
\text { (in. } H_{2} O \text { ) }\end{array}$ & $\begin{array}{c}\text { Sqrt } \\
\Delta \mathbf{P}\end{array}$ & $\underset{(\widetilde{F})}{\operatorname{Temp}}$ & $\begin{array}{c}\text { Velocity } \\
\text { (N) }\end{array}$ & Port & Point & $\begin{array}{c}\Delta P \\
\left(\text { in. } H_{2} O\right)\end{array}$ & $\underset{\Delta P}{\text { Sqrt. }}$ & $\underset{(F)}{\text { Temp }}$ & $\begin{array}{c}\text { Velocity } \\
\text { (V) }\end{array}$ \\
\hline A 01 & 0.81 & 0.9000 & 306 & 60.74 & & 01 & 0.78 & 0.8832 & 303 & 59.49 \\
\hline A 02 & 0.79 & 0.8888 & 306 & 59.99 & & 02 & 0.75 & 0.8660 & 304 & 58.37 \\
\hline A 04 & 0.57 & 0.7550 & 304 & 50.89 & & 04 & 0.60 & 0.7746 & 303 & 52.18 \\
\hline
\end{tabular}

$\begin{array}{llllllllll}\text { B 01 } & 0.75 & 0.8660 & 304 & 58.37 & \text { D 01 } & 0.75 & 0.8660 & 303 & 58.33 \\ \text { B 02 } & 0.73 & 0.8544 & 303 & 57.55 & \text { D 02 } & 0.75 & 0.8660 & 303 & 58.33 \\ \text { B 03 } & 0.70 & 0.8367 & 303 & 56.36 & \text { D 03 } & 0.69 & 0.8307 & 302 & 55.92 \\ \text { B 04 } & 0.59 & 0.7681 & 303 & 51.74 & \text { D 04 } & 0.61 & 0.7810 & 302 & 52.57\end{array}$

\begin{tabular}{ll}
\hline Method 2 Results & \\
Average $\Delta P$ & 0.7081 \\
Average Sqrt $\Delta P$ & 0.8403 \\
Average Velocity Vs (ft/sec) & 56.613 \\
No WAF Applied to this Test & \\
Q - ACFM & $2,757,509$ \\
Qsd - DSCFM & $1,693,250$ \\
Qs - SCFM & $1,904,668$ \\
Qs - SCFH & $114,280,077$
\end{tabular}




$\begin{array}{ll}\text { Project No: } & \text { M22E1180 } \\ \text { Company: } & \text { MidAmerican } \\ \text { Plant: } & \text { Louisa Generating Station } \\ \text { Source: } & \text { Unit 1 Stack } \\ \text { Pitot ID: } & 789 \mathrm{~A} \\ \text { Pitot Coefficient: } & 0.84\end{array}$

\begin{tabular}{ll}
\hline Test Parameters & \\
$\mathrm{P}_{\text {bar }}$ - Barometric pressure, inches $\mathrm{Hg}$ & 29.96 \\
$\mathrm{P}_{\mathrm{g}}$ - Stack Pressure, inches of $\mathrm{H}_{2} \mathrm{O}$ & -1.00 \\
$\mathrm{P}_{\mathrm{s}}$ - Absolute stack pressure, inches $\mathrm{Hg}$ & 29.89 \\
$\mathrm{t}_{\mathrm{s}}-$ Average stack temperature, $^{\circ} \mathrm{F}$ & 299.8 \\
$\% \mathrm{CO}_{2}$ & 14.1 \\
$\% \mathrm{O}_{2}$ & 5.7 \\
$\% \mathrm{~N}_{2}$ & 80.2 \\
$\mathrm{Md}$ - dry basis Ib/lb mole & 30.48 \\
$\mathrm{Ms}$ - wet basis lb/lb mole & 28.95 \\
Stack Diameter, Feet & 32.15 \\
Cross Sectional Area of Stack, $\mathrm{Ft}^{2}$ & 811.81
\end{tabular}

$\begin{array}{ll}\text { Source Condition: } & \text { Normal } \\ \text { Run No.: } & \text { Post 2/Pre 3 } \\ \text { Date: } & 2 / 9 / 2006 \\ \text { Start Time: } & 15: 20 \\ \text { End Time: } & 15: 35 \\ \text { RM Testers: } & \text { CFM/MJK }\end{array}$

Moisture Determination

Meter Calibration: $\quad 0.998$

Initial Meter Volume: $\quad 256.113$

Final Meter Volume: $\quad 260.358$

Meter Temperature: $\quad 74.62$

Meter Volume Vm(std): $\quad 4.218$

Meter Volume Vw(std): $\quad 0.594$

Delta H: $\quad 2.50$

Train Initial Wt: $\quad 698.900$

Train Final Wt: $\quad \mathbf{7 1 1 . 5 0 0}$

Condensate Initial Vol: $\quad 0.000$

Condensate Final Vol: $\quad 0.000$

Bws - Moisture content fraction $\quad 0.123$

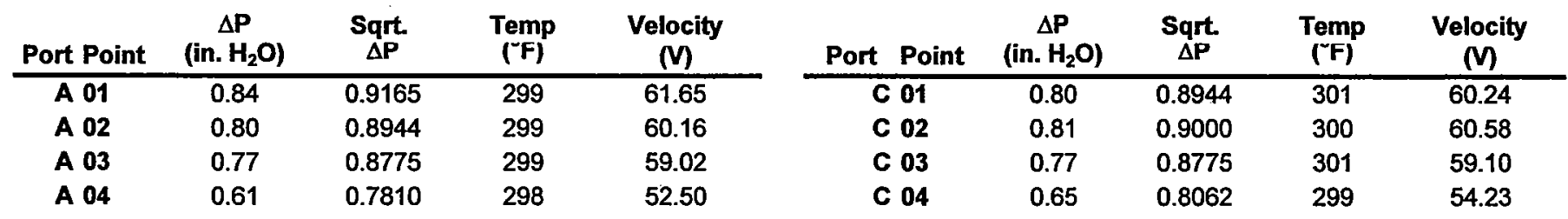

$\begin{array}{llllllllll}\text { B 01 } & 0.81 & 0.9000 & 300 & 60.58 & \text { D 01 } & 0.84 & 0.9165 & 301 & 61.73 \\ \text { B 02 } & 0.80 & 0.8944 & 300 & 60.20 & \text { D 02 } & 0.79 & 0.8888 & 301 & 59.86 \\ \text { B 03 } & 0.78 & 0.8832 & 300 & 59.44 & \text { D 03 } & 0.76 & 0.8718 & 300 & 58.68 \\ \text { B 04 } & 0.66 & 0.8124 & 299 & 54.64 & \text { D 04 } & 0.65 & 0.8062 & 299 & 54.23\end{array}$

\begin{tabular}{ll}
\hline Method 2 Results & \\
Average $\Delta P$ & 0.7588 \\
Average Sqrt $\Delta P$ & 0.8701 \\
Average Velocity Vs (ft/sec) & 58.538 \\
No WAF Applied to this Test & \\
Q - ACFM & $2,851,267$ \\
Qsd - DSCFM & $1,735,856$ \\
Qs - SCFM & $1,979,311$ \\
Qs - SCFH & $118,758,668$
\end{tabular}




$\begin{array}{ll}\text { Project No: } & \text { M22E1180 } \\ \text { Company: } & \text { MidAmerican } \\ \text { Plant: } & \text { Louisa Generating Station } \\ \text { Source: } & \text { Unit 1 Stack } \\ \text { Pitot ID: } & 789 \mathrm{~A} \\ \text { Pitot Coefficient: } & 0.84\end{array}$

\begin{tabular}{ll}
\hline Test Parameters & \\
$\mathrm{P}_{\text {bar }}$ - Barometric pressure, inches $\mathrm{Hg}$ & 29.96 \\
$\mathrm{P}_{\mathrm{g}}$ - Stack Pressure, inches of $\mathrm{H}_{2} \mathrm{O}$ & -1.00 \\
$\mathrm{P}_{\mathrm{s}}$ - Absolute stack pressure, inches $\mathrm{Hg}$ & 29.89 \\
$\mathrm{t}_{\mathrm{s}}$ - Average stack temperature, ${ }^{\mathrm{U}} \mathrm{F}$ & 303.1 \\
$\% \mathrm{CO}_{2}$ & 14.0 \\
$\% \mathrm{O}_{2}$ & 5.6 \\
$\% \mathrm{~N}_{2}$ & 80.4 \\
$\mathrm{Md}$ - dry basis lb/lb mole & 30.46 \\
$\mathrm{Ms}$ - wet basis lb/lb mole & 29.24 \\
Stack Diameter, Feet & 32.15 \\
Cross Sectional Area of Stack, $\mathrm{Ft}^{2}$ & 811.81
\end{tabular}

$\begin{array}{ll}\text { Source Condition: } & \text { Normal } \\ \text { Run No.: } & \text { Post } 3 \\ \text { Date: } & 2 / 9 / 2006 \\ \text { Start Time: } & 16: 32 \\ \text { End Time: } & 16: 51 \\ \text { RM Testers: } & \text { CFM/MJK }\end{array}$

\begin{tabular}{|c|c|c|c|c|c|c|c|c|c|c|}
\hline Port Point & $\underset{\text { (in. } H_{2} \mathrm{O} \text { ) }}{\Delta P}$ & $\underset{\Delta \mathbf{P}}{\text { Sqrt }}$ & $\begin{array}{c}\text { Temp } \\
\left({ }^{\prime} F\right)\end{array}$ & $\begin{array}{c}\text { Velocity } \\
\text { (V) }\end{array}$ & Port & Point & $\underset{\text { (in. } \mathrm{H}_{2} \mathrm{O} \text { ) }}{\Delta \mathrm{P}}$ & $\underset{\Delta \mathbf{P}}{\text { Sqrt. }}$ & $\underset{(-F)}{\text { Temp }}$ & $\begin{array}{c}\text { Velocity } \\
\text { (V) }\end{array}$ \\
\hline A 01 & 0.83 & 0.9110 & 303 & 61.13 & & 01 & 0.84 & 0.9165 & 305 & 61.58 \\
\hline A 02 & 0.82 & 0.9055 & 303 & 60.76 & & 02 & 0.82 & 0.9055 & 304 & 60.80 \\
\hline A 04 & 0.67 & 0.8185 & 302 & 54.89 & & 04 & 0.64 & 0.8000 & 303 & 53.68 \\
\hline
\end{tabular}

$\begin{array}{llllllllll}\text { B 01 } & 0.86 & 0.9274 & 303 & 62.22 & \text { D 01 } & 0.82 & 0.9055 & 303 & 60.76 \\ \text { B 02 } & 0.85 & 0.9220 & 304 & 61.90 & \text { D 02 } & 0.80 & 0.8944 & 303 & 60.01 \\ \text { B 03 } & 0.80 & 0.8944 & 304 & 60.05 & \text { D 03 } & 0.82 & 0.9055 & 302 & 60.72 \\ \text { B 04 } & 0.69 & 0.8307 & 303 & 55.74 & \text { D 04 } & 0.68 & 0.8246 & 301 & 55.26\end{array}$

\begin{tabular}{ll}
\hline Method 2 Results & \\
Average $\Delta P$ & 0.7844 \\
Average Sqrt $\Delta P$ & 0.8848 \\
Average Velocity Vs (ft/sec) & 59.358 \\
No WAF Applied to this Test & \\
Q - ACFM & $2,891,207$ \\
Qsd - DSCFM & $1,802,341$ \\
Qs - SCFM & $1,998,161$ \\
Qs - SCFH & $119,889,674$
\end{tabular}




\section{CALIBRATION PROCEDURES}

\section{PITOT TUBES}

The pitot tubes used during this test program are fabricated according to the specification described and illustrated in the Code of Federal Regulations, Title 40, Part 60, Appendix A, Methods 1 through 5 as published in the Federal Register, Volume 42, No. 160; hereafter referred to by the appropriate method number. The pitot tubes comply with the alignment specifications in Method 2, Section 4; and the pitot tube assemblies are in compliance with specifications in the same section.

Pitot tube assemblies are calibrated in accordance with Method 2, Section 4, against a standard hemispherical pitot utilizing a wind tunnel meeting the specification in Method 2, Section 4.1.2.

\section{TEMPERATURE SENSING DEVICES}

The potentiometer and thermocouples are calibrated against a mercury thermometer in a calibration well. Alternatively, readings are checked utilizing a NBS traceable millivolt source.

\section{DRY GAS METERS}

The test meters are calibrated according to Method 5, Section 5.3 and "Procedures for Calibrating and Using Dry Gas Volume Meters as Calibration Standards" by P.R. Westlin and R.T. Shigehara, March 10, 1978.

\section{ANALYTICAL BALANCE}

The accuracy of the analytical balance is checked with Class S, Stainless Steel Type 303 weights manufactured by F. Hopken and Son, Jersey City, New Jersey. 


\section{GE Energy}

\section{Gas Meter Calibration Train}

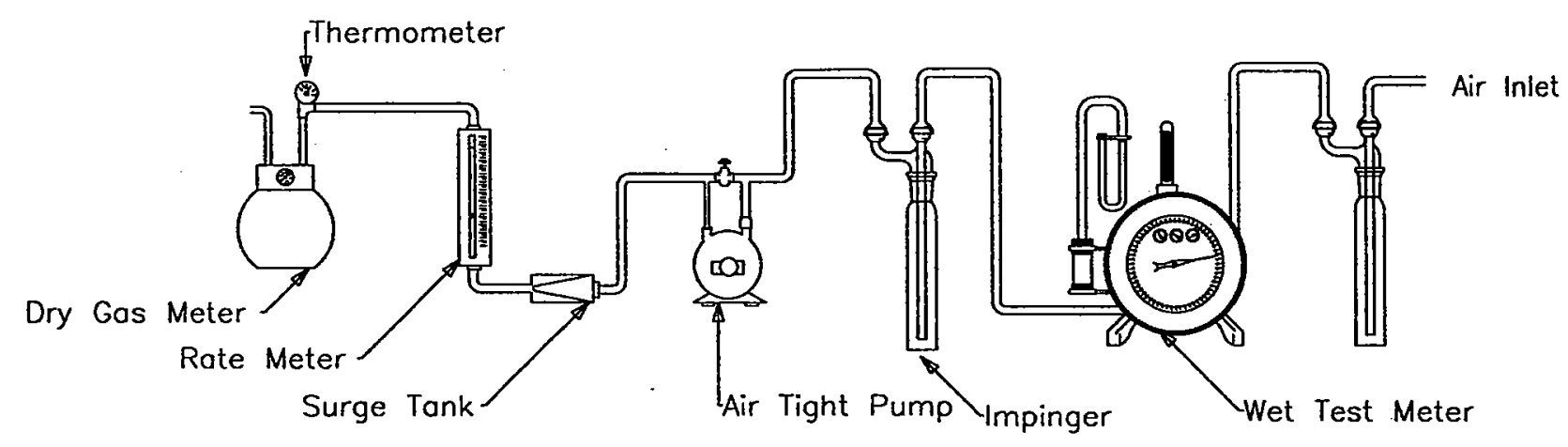

Dwg - AF 

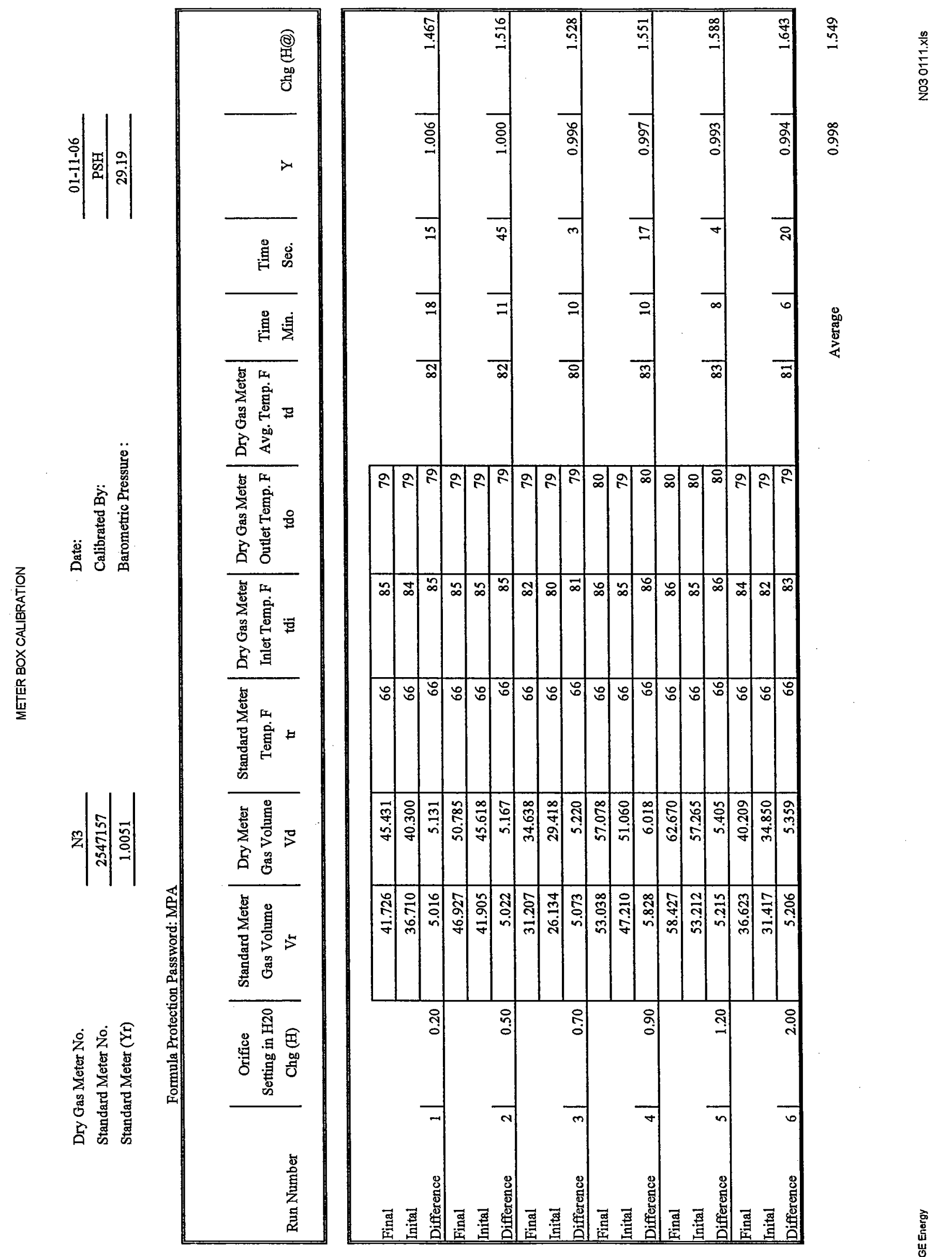

웅 :

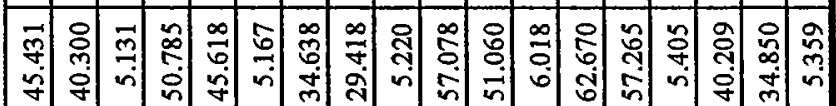

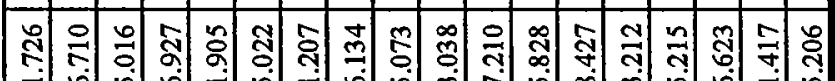

च 


\section{STACK TEMPERATURE SENSOR CALIBRATION DATA FORM (FOR K-TYPE THERMOCOUPLES)}

EPA Control Module Number: N3 Name: PSH
Ambient Temperature:
$61^{\circ} \mathrm{F}$
Date: 02-13-06

Omega Engineering Calibrator Model No. CL23A Serial \#

$\mathrm{T}-124947$

Date Of Calibration Verification:

May 11, 2005

Primary Standards Directly Traceable to National Institute of Standards and Technology (NIST)

\begin{tabular}{|c|c|c|}
\hline $\begin{array}{c}\text { Reference }^{\mathrm{a}} \\
\text { Source } \\
\text { Temperature, }\left({ }^{\circ} \mathrm{F}\right)\end{array}$ & $\begin{array}{c}\text { Test } \\
\text { Thermometer } \\
\text { Temperature, }\left({ }^{\circ} \mathbf{F}\right)\end{array}$ & $\begin{array}{c}\text { Temperature } \\
\text { Difference, \% }\end{array}$ \\
\hline 0 & -1 & 0.2 \\
\hline 600 & 600 & 0.0 \\
\hline 1200 & 1200 & 0.0 \\
\hline
\end{tabular}

(Ref. Temp., ${ }^{\circ} \underline{F+460)-(\text { Test Therm. Temp., }}{ }^{\circ} \underline{F+460)} * 100<=1.5 \%$

Ref. Temp., ${ }^{\circ} \mathrm{F}+460$ 


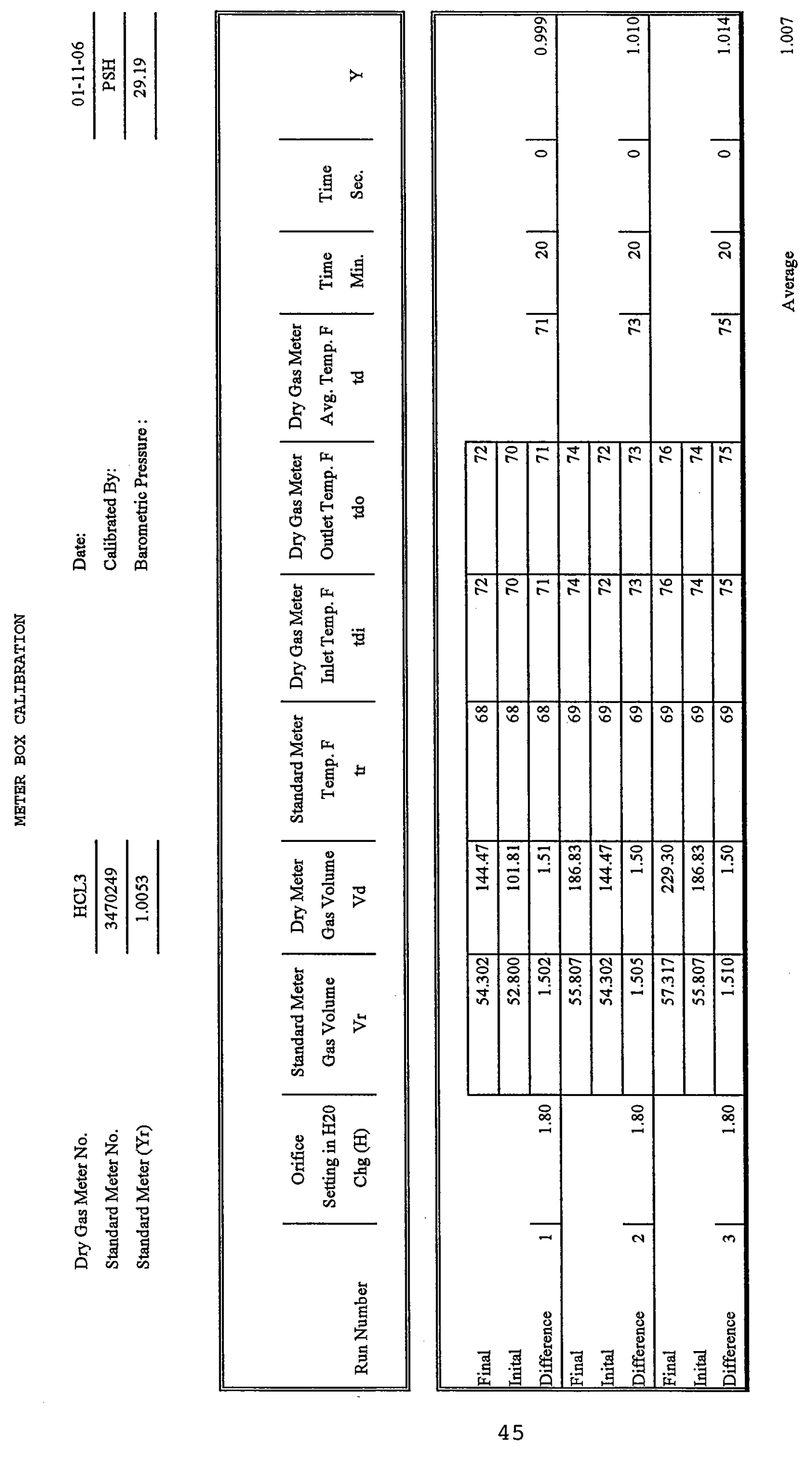




\section{STACK TEMPERATURE SENSOR CALIBRATION DATA FORM (FOR K-TYPE THERMOCOUPLES)}

EPA Control Module Number:

Ambient Temperature:

Omega Engineering Calibrator Model No. CL23A Serial \#

Date Of Calibration Verification:
Name: PSH

Date: 01-11-06

$\mathrm{T}-124947$

May 11, 2005

Primary Standards Directly Traceable to National Institute of Standards and Technology (NIST)

\begin{tabular}{|c|c|c|}
\hline $\begin{array}{c}\text { Reference } \\
\text { Source } \\
\text { Temperature, }\left({ }^{\circ} \mathbf{F}\right)\end{array}$ & $\begin{array}{c}\text { Test } \\
\text { Thermometer } \\
\text { Temperature, }\left({ }^{\circ} \mathbf{F}\right)\end{array}$ & $\begin{array}{c}\text { Temperature } \\
\text { Difference, } \%\end{array}$ \\
\hline 0 & -1 & 0.2 \\
\hline 600 & 599 & 0.1 \\
\hline 1200 & 1200 & 0.0 \\
\hline
\end{tabular}

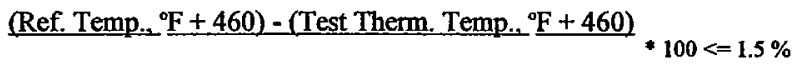

Ref. Temp., $\mathbf{F}+460$ 


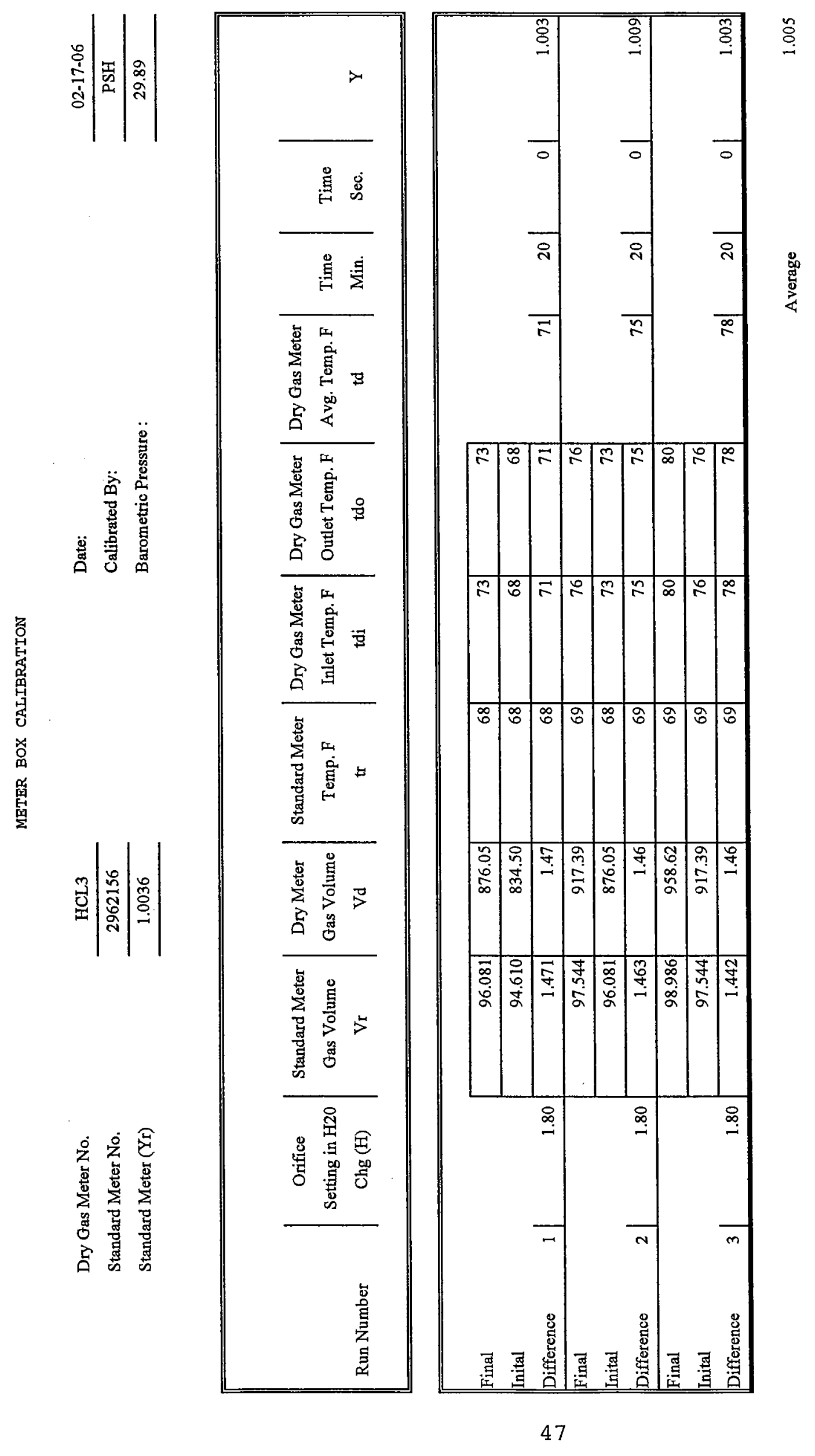




\section{STACK TEMPERATURE SENSOR CALIBRATION DATA FORM (FOR K-TYPE THERMOCOUPLES)}

EPA Control Module Number:

HCL3

Name: PSH

Ambient Temperature:

$68^{-r}$

Date: $01-11-06$

Omega Engineering Calibrator Model No. CL23A Serial \#

T-124947

Date Of Calibration Verification:

May 11, 2005

Primary Standards Directly Traceable to National Institute of Standards and Technology (NIST)

\begin{tabular}{|c|c|c|}
\hline $\begin{array}{c}\text { Reference } \\
\text { Source } \\
\left.\text { Temperature, ( }{ }^{\mathrm{s}} \mathbf{F}\right)\end{array}$ & $\begin{array}{c}\text { Test } \\
\text { Thermometer } \\
\text { Temperature, }\left({ }^{\circ} \mathbf{F}\right)\end{array}$ & $\begin{array}{c}\text { Temperature } \\
\text { Difference, } \%\end{array}$ \\
\hline 0 & -1 & 0.2 \\
\hline 600 & 599 & 0.1 \\
\hline 1200 & 1200 & 0.0 \\
\hline
\end{tabular}

(Ref. Temp. $\left.{ }^{\circ}{ }^{F}+460\right)-\left(\right.$ Test Therm. Temp.. ${ }^{\circ} \underline{F+460)}$

$* 100<=1.5 \%$

Ref. Temp., $\mathrm{F}+460$ 


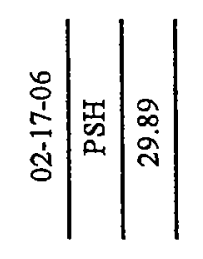
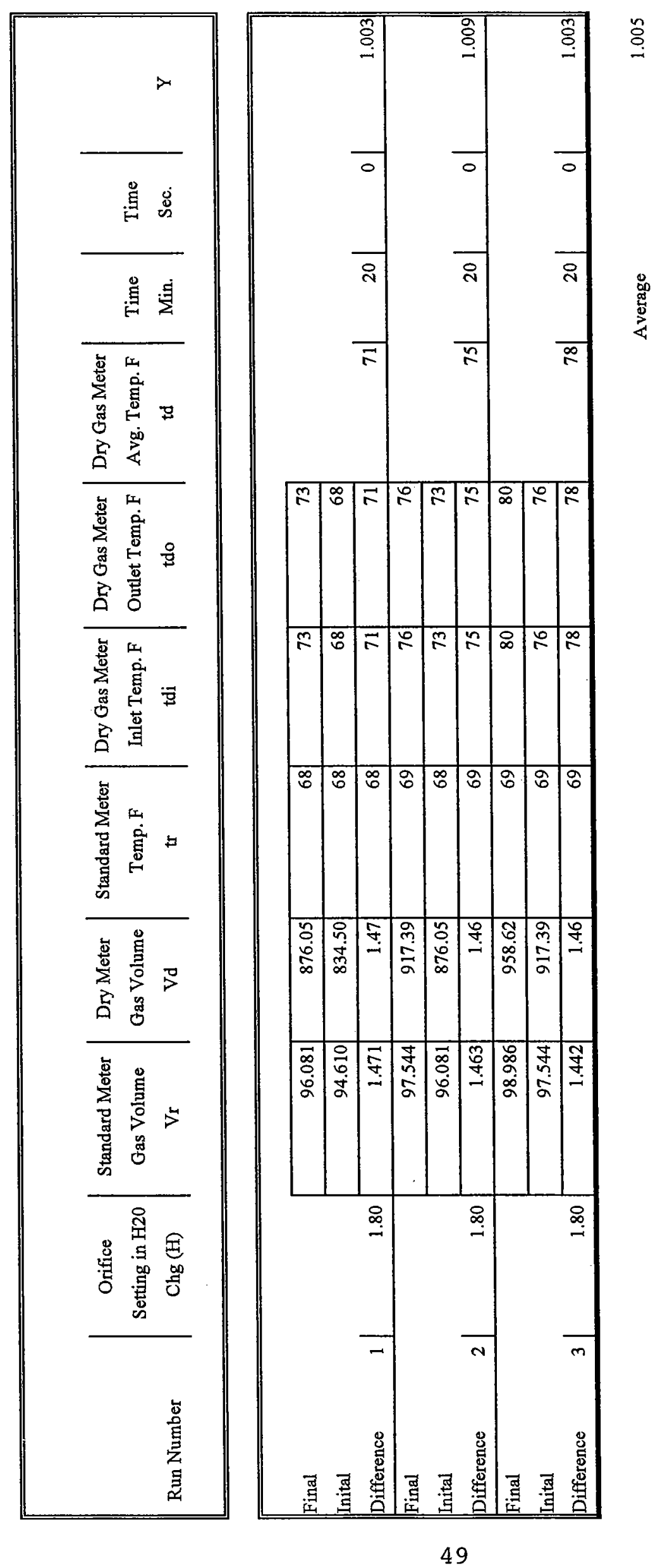

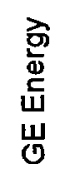




\section{STACK TEMPERATURE SENSOR CALIBRATION DATA FORM (FOR K-TYPE THERMOCOUPLES)}

EPA Control Module Number:

Ambient Temperature:

Omega Engineering Calibrator Model No. CL23A Serial \#

Date Of Calibration Verification:

Primary Standards Directly Traceable to National Institute of Standards and Technology (NIST)

\begin{tabular}{|c|c|c|}
\hline $\begin{array}{c}\text { Reference } \\
\text { Source } \\
\text { Temperature, }\left({ }^{2} \mathbf{F}\right)\end{array}$ & $\begin{array}{c}\text { Test } \\
\text { Thermometer } \\
\text { Temperature, }\left({ }^{\circ} \mathbf{F}\right)\end{array}$ & $\begin{array}{c}\text { Temperature } \\
\text { Difference, \% }\end{array}$ \\
\hline 0 & 0 & 0.0 \\
\hline 600 & 600 & 0.0 \\
\hline 1200 & 1200 & 0.0 \\
\hline
\end{tabular}

Name: PSH

Date: $02-17-06$
T-124947

May 11,2005

\section{(Ref. Temp., $\left.{ }^{\circ} \mathrm{F}+460\right)-\left(\right.$ Test Therm Temp., ${ }^{\circ} \underline{F+460)} * 100<=1.5 \%$}

Ref. Temp., $F+460$ 


\section{PITOT TRAVERSE DATA}

Project: ADA-ES (MIDAMERTCAN POWER)

Location: UNAT , STACK

Date: $2 / 8 / 06 \quad$ Test No: PRE

Time: $\quad 1045-1105$

\begin{tabular}{|c|c|c|c|c|c|c|c|c|c|}
\hline Point No, & $\Delta \mathbf{P}$ & $\sqrt{\Delta \mathrm{P}}$ & ts & $\alpha$ & Point No. & $\Delta \mathbf{P}$ & $\sqrt{\Delta \mathrm{P}}$ & $t_{s}$ & $\alpha$ \\
\hline $1-1$ & 75 & & 299 & & & & & & \\
\hline 2 & .70 & & 298 & & & & & & \\
\hline 3 & .69 & & 297 & & & & . & & \\
\hline 4 & .52 & & 296 & 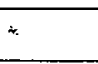 & $\cdots$ & & & & \\
\hline & & & & & $\because$ & & & & \\
\hline $2=1$ & .76 & & 298 & & & & & & \\
\hline 2 & .78 & & 298 & & & & & & \\
\hline 3 & .78 & & 296 & & & & & & \\
\hline 4 & .61 & & 296 & & & & & & \\
\hline & & & & & & & & & \\
\hline $2-1$ & 76 & & 297 & & & & & & \\
\hline$\therefore 2$ & 27 & & 298 & & & & & & \\
\hline 3 & .76 & & 298 & & & & & & \\
\hline 4 & 61 & & 297 & & & & & & \\
\hline & & & & & & & & & \\
\hline $9-1$ & 80 & & 299 & & & & & & \\
\hline 2 & .78 & & 299 & & & & & & \\
\hline 3 & 119 & & 299 & & & & & & \\
\hline 4 & 83 & & 299 & & & & & & \\
\hline & & & & & & & & & ' \\
\hline & & & & & & & & & \\
\hline & & & & & & & & & \\
\hline & & & & & & & & & \\
\hline & & & & & & & & & \\
\hline
\end{tabular}

Preliminary Velocity Calculation (This data has not been peer reviewed and may not be accurate)

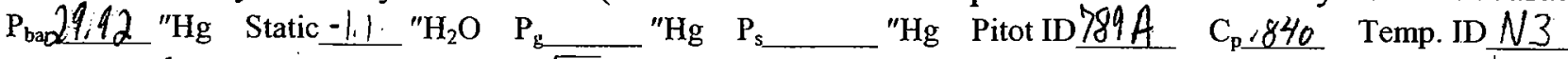
$0.44 \times 13.5 \% \mathrm{CO}_{2}=-\sqrt{\Delta \mathrm{P}} \ldots \mathrm{t}_{\mathrm{s}}{ }^{\circ} \mathrm{F} \quad \mathrm{T} \quad{ }^{\circ} \mathrm{R} \quad$ Flue Area $\left.8 / 1 . \mathrm{g}\right)$

$0.32 \times 6.5 \% \mathrm{O}_{2}=+$

$0.28 \times \square \mathrm{N}_{2}=+\longleftarrow \mathrm{B}_{\mathrm{ws}} .1 / 5 \quad 1-\mathrm{B}_{\mathrm{ws}}$ $\mathrm{Md} \times$ $1-\mathrm{Bws})+(18 \times$

Bws)

$$
\mathrm{v}_{\mathrm{s}}=85.49 \times
$$$$
\mathrm{Cp} \times \sqrt{\frac{\left(-\ldots \ldots \ldots-\mathrm{Ts}^{\circ} \mathrm{R}\right.}{\mathrm{Ms}_{\ldots} \mathrm{Ps}_{-\ldots}}} \times
$$

Duct Dimensions $32.151^{\prime}$ dhem

Disturbance: Upstream

Downstream

$\mathrm{Q}_{\mathrm{acfin}}=\ldots$ Vs $\times \quad$ Flue Area $\times 60=3,292,980$ acfm $\mathrm{ft} / \sec (\mathrm{Vs})$

$\mathrm{Q}_{\text {scin }}=17.647 \times \mathrm{ACFM} \times \frac{\mathrm{Ps}}{\mathrm{Ts}^{\circ} \mathrm{R}}=2,288,534 \mathrm{SCFM}$

Port Length 18 Inches

$\mathrm{Q}_{\mathrm{dscfin}}=17.647 \times \mathrm{ACFM} \times \frac{\mathrm{Ps}}{\mathrm{Ts}^{\circ} \mathrm{R}} \times(1-\mathrm{Bws})=2,025,352 \mathrm{DSCFM}$

Pre-test leak check $0.01 \mathrm{H}_{2} \mathrm{O}^{3}$ "

Post-test leak check $0.0 \ell^{\prime \prime} \mathrm{H}_{2}^{\prime \prime} \mathrm{O}$ SCFH 137,312,030 Data Taken By: GFM/MJK 


\section{PITOT TRAVERSE DATA}

Project: ABAES/MTAAMERICAN POWER)

Location: UNFT I STACK

Date: $2 / 8 / 06$ Test No: POST $1 / P_{R E 2} \quad$ Time: $1244-1259$

\begin{tabular}{|c|c|c|c|c|c|c|c|c|c|}
\hline Poin No & $\Delta P$ & $\sqrt{\Delta P}$ & 4 & a. & Point No. & $\Delta P$ & $\sqrt{\Delta \mathrm{P}}$ & th & o \\
\hline 1.1 & 80 & & 297 & & & & & & \\
\hline 2 & 71 & & 217 & & & & $\therefore$ & & \\
\hline 3 & .73 & & 297 & & & & & & \\
\hline 4 & .51 & & 297 & & & & & & \\
\hline & & & & & & & & & \\
\hline $2-1$ & .79 & & 297 & & & & & & \\
\hline 2 & 71 & & 297 & & & & & & \\
\hline 3 & .69 & & 296 & & & & & & \\
\hline 4 & .55 & & 296 & & & & & & \\
\hline & & & & & & & & & \\
\hline $2-1$ & .77 & & 217 & & & & & & \\
\hline 2 & .72 & & 297 & & & & & & \\
\hline 3 & .71 & & 296 & & & . & & & \\
\hline 4 & .58 & & 296 & & & & & & \\
\hline & & & & & & & & & \\
\hline $3-1$ & .72 & & 298 & & & & & & \\
\hline 2 & .67 & & 298 & & & & & & \\
\hline 3 & .65 & & 295 & & & & & & \\
\hline 4 & .58 & & 295 & & & & & & \\
\hline & & & & & & & & & . \\
\hline & & & & & & & & & \\
\hline & & & & & & & & & \\
\hline & & & & & & & & & \\
\hline & & & & & & & & & \\
\hline
\end{tabular}

Preliminary Velocity Calculation (This data has not been peer reviewed and may not be accurate)

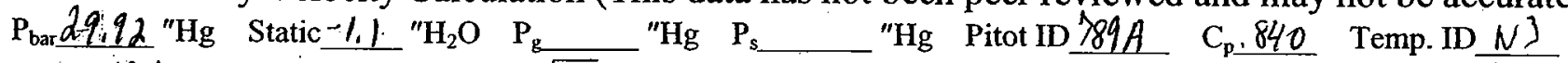

$0.44 \times 13.1 . \% \mathrm{CO}_{2}=$

$0.32 \times 6.7 \% \mathrm{O}_{2}=+$

$0.28 \times \% \mathrm{~N}_{2}=+$ Md $\times$

$$
\begin{aligned}
& +B_{w s} \ldots 1151-B_{w s} \\
& 1-\mathrm{Bws})+(18 \times \\
& \mathrm{v}_{\mathrm{s}}=85.49 \times \times_{---} \mathrm{Cp} \times \sqrt{\frac{(\ldots \ldots-\ldots) \mathrm{Ts}{ }^{\circ} \mathrm{R}}{\mathrm{Ms}_{\ldots} \mathrm{Ps}^{\mathrm{Ps}}}} \times
\end{aligned}
$$

$\mathrm{Q}_{\text {acin }}=\ldots$ Vs $\times$ Flue Area $\times 60=3,208,343 \quad \mathrm{acfm}$

$\mathrm{Q}_{\text {scfm }}=17.647 \times \mathrm{ACFM} \times \frac{\mathrm{Ps}}{\mathrm{Ts}^{\circ} \mathrm{R}}=2,232,844 \mathrm{SCFM}$

$Q_{\text {dsfim }}=17.647 \times \mathrm{ACFM} \times \frac{\mathrm{Ps}^{\mathrm{R}}}{\mathrm{Ts}^{\circ} \mathrm{R}} \times(1-\mathrm{Bws})=1,976,067$

DSCFM

Pre-test leak check 0.0 " $\mathrm{H}_{2} \mathrm{O} Q{ }^{\prime \prime}$

Post-test leak check $\left.\underline{0.0 .} \mathrm{H}_{2} \mathrm{O}\right\}^{\prime \prime}$

SCFH $133,970,630$
Flue Area $\overline{811.81} \mathrm{ft}^{2}$

Duct Dimensions 32.15/'dionits.

Disturbance: Upstream

Downstream $\mathrm{ft} / \mathrm{sec}(\mathrm{Vs})$

Port Length $18 \quad$ Inches 


\section{PITOT TRAVERSE DATA}

Project: ADA-ESTMIAAMERICAN POWER

Location: UNTT I STACK

Date: $2 / 8 / 06 \quad$ Test No: POST2/PRB3 Time: $1424-1433$

\begin{tabular}{|c|c|c|c|c|c|c|c|c|c|}
\hline Point No. & $\Delta P$ & $\sqrt{\Delta P}$ & to & o & Point No. & $\Delta \mathrm{P}$ & $\sqrt{\Delta \mathrm{P}}$ & $t_{1}$ & 10 \\
\hline $1-1$ & .77 & & 298 & & & & & & \\
\hline 2 & .75 & & 298 & & & & $\therefore$ & & \\
\hline 3 & .71 & & 298 & & & & & & \\
\hline 4 & .56 & & 217 & & & & & & \\
\hline & & & & & & & & & \\
\hline $2-1$ & .79 & & 298 & & & & & & \\
\hline 2 & .78 & & 298 & & & & & & \\
\hline 3 & .70 & & 299 & & & & & & \\
\hline 4 & .60 & & 298 & & & & & & \\
\hline & & & & & & & & & \\
\hline $2-1$ & .78 & & 299 & & & & & & \\
\hline 2 & 77 & & 299 & & & & & & \\
\hline 3 & .71 & & 299 & & & & & & \\
\hline 4 & .59 & & 298 & & & & & & \\
\hline & & & & & & & & & \\
\hline $3-1$ & .74 & & 298 & & & & & & \\
\hline 2 & 70 & & 299 & & & & & & \\
\hline 3 & 12 & & 299 & & & & & & \\
\hline 4 & .59 & & 298 & & & & & & \\
\hline & & & & & & & & & . \\
\hline & & & & & & & & & \\
\hline & & & & & & & & & \\
\hline & & & & & & & & & \\
\hline & & & & & & & & & \\
\hline
\end{tabular}

Preliminary Velocity Calculation (This data has not been peer reviewed and may not be accurate)

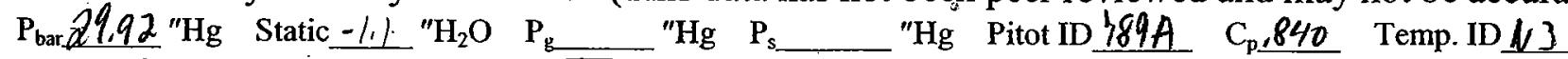
$0.44 \times 13.5 \% \mathrm{CO}_{2}=$ $0.32 \times 6.5 \% \mathrm{O}_{2}=+$ $0.28 \times \quad \mathrm{N}_{2}=+\square \mathrm{B}_{\mathrm{ws} \_.097} 1-\mathrm{B}_{\mathrm{ws}}$ $0.28 \times \mathrm{N}_{2}=+\square \mathrm{B}_{\mathrm{ws} \ldots .097} 1-\mathrm{B}_{\mathrm{ws}}$ $\sqrt{\Delta \bar{P}} \quad{ }_{t_{s}}{ }^{\circ} \quad T$ $\mathrm{Md} \times \quad{ }^{1-\mathrm{Bws})}+(18 \times \quad \mathrm{Bws})=$

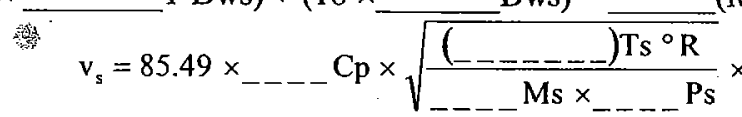

R F Flue Area $81 / 81 \mathrm{ft}^{2}$ Duct Dimensions 32,15/' dimenth Disturbance: Upstream

Downstream

$\mathrm{Q}_{\mathrm{acfin}}=\ldots$ Vs $\times$ _ Flue Area $\times 60=3,257,892 \quad \mathrm{acfm}$

$\mathrm{Q}_{\text {scin }}=17.647 \times \mathrm{ACFM} \times \frac{\mathrm{Ps}}{\mathrm{Ts}^{\circ} \mathrm{R}}=2,262,262 \mathrm{SCFM}$

$\mathrm{Q}_{\text {dscfin }}=17.647 \times \mathrm{ACFM} \times \frac{\mathrm{Ps}_{\mathrm{s}}}{\mathrm{Ts}^{\circ} \mathrm{R}} \times(1-\mathrm{Bws})=2,042,841$ DSCFM

Pre-test leak check $0.0{ }^{\prime \prime} \mathrm{H}_{2} \mathrm{O} e^{1 /} \quad$ SCFA $135,736,948$

Post-test leak check $0.0 " \mathrm{H}_{2} \mathrm{O} \in 3^{\prime \prime}$

Data Taken By: CFM/MJK 


\section{PITOT TRAVERSE DATA}

Project: ADA-ES(MADANERCLCAN PQWER)

Location: $\mid$ NLT I STACK

Date: $2 / 8 / 06$

Test No: POST3

Time: $\quad \underline{1545-1558}$

\begin{tabular}{|c|c|c|c|c|c|c|c|c|c|}
\hline Ponno & $\Delta \mathbf{p}$ & $\sqrt{\Delta \mathrm{P}}$ & tro & a & Point No. & $\Delta, \Delta \mathrm{P}$ & $\sqrt{\Delta \mathrm{P}}$ & $\mathrm{H}_{\mathrm{s}}$ & 40 \\
\hline $1-1$ & .70 & & 297 & & & & & & \\
\hline 2 & .69 & 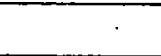 & 297 & & & & . & & \\
\hline 3 & .63 & & 296 & & C & - & & & \\
\hline 4 & .52 & & 216 & & & & & & \\
\hline & & & & & & & & & \\
\hline $2-1$ & .71 & & 297 & & & & & & \\
\hline 2 & .72 & & 296 & & & & & & \\
\hline 2 & .74 & & 296 & & & & & & \\
\hline 4 & .57 & & 296 & & & & & & \\
\hline & & & & & & & & & \\
\hline $2-1$ & .72 & & 297 & & & & & & \\
\hline 2 & .72 & & 296 & & & & & & \\
\hline 3 & .7 & & 296 & & & & & & \\
\hline 4 &, 60 & & 29 & & & & & & \\
\hline & & & & & & & & & \\
\hline $3-1$ & .69 & & 296 & & & & & & \\
\hline 2 & .70 & & 296 & & & & & & \\
\hline 3 & .69 & & 296 & & & & & & \\
\hline 4 & .63 & & 215 & & & & & & \\
\hline & & & & & & & & & \\
\hline & & & & & & & & & \\
\hline & & & & & & & & & \\
\hline & & &. & & & & & & \\
\hline & & & & & & & & & \\
\hline
\end{tabular}

Preliminary Velocity Calculation (This data has not been peer reviewed and may not be accurate) $B H=1,549$ $\mathrm{P}_{\mathrm{bar}} 29.92 " \mathrm{Hg}$ Static-1.1. $" \mathrm{H}_{2} \mathrm{O} \quad \mathrm{P}_{\mathrm{g}} \quad \mathrm{Hg} \quad \mathrm{P}_{\mathrm{s}} \quad \mathrm{Hg}$ Pitot ID $789 \mathrm{~A} \quad \mathrm{C}_{\mathrm{p}, 840}$ Temp. ID N3

$0.44 \times 13,3 \% \mathrm{CO}_{2}=$ $0.32 \times 6.8 \% \mathrm{O}_{2}=+$ $0.28 \times \quad \% \mathrm{~N}_{2}=+$ $\mathrm{Md} \times$

$$
\begin{aligned}
& \text { 1-Bws })+(18 x \\
& v_{s}=85.49 \times
\end{aligned}
$$
$\sqrt{\Delta \mathbf{P}}$ $B_{w s} \cdot$ II $1-B_{w s}$ (Ms)

Flue Area $81 / .8 / \mathrm{ft}^{2}$ Duct Dimensions 32.15,' diancts Disturbance: Upstream Downstream $\mathrm{ft} / \sec (\mathrm{Vs})$

Port Length $18 \quad$ Inches

$\mathrm{Q}_{\text {scfin }}=17.647 \times \mathrm{ACFM} \times \frac{\mathrm{Ps}}{\mathrm{Ts}^{\circ} \mathrm{R}}=2,215,974 \mathrm{SCFM}$

$\mathrm{Q}_{\mathrm{dscfin}}=17.647 \times \mathrm{ACFM} \times \frac{\mathrm{Ps}}{\mathrm{Ts}^{\circ} \mathrm{R}} \times(1-\mathrm{Bws})=1,970,001$ DSCFM

Pre-test leak check $0.0^{\prime \prime} \mathrm{H}_{2} \mathrm{O} \ell^{\prime \prime}$

Post-test leak check 0.0 " $\mathrm{H}_{2} \mathrm{O} Q 3$ "

SCFH $132,958,442$ 


\section{METHOD 26 FIELD DATA SHEET}

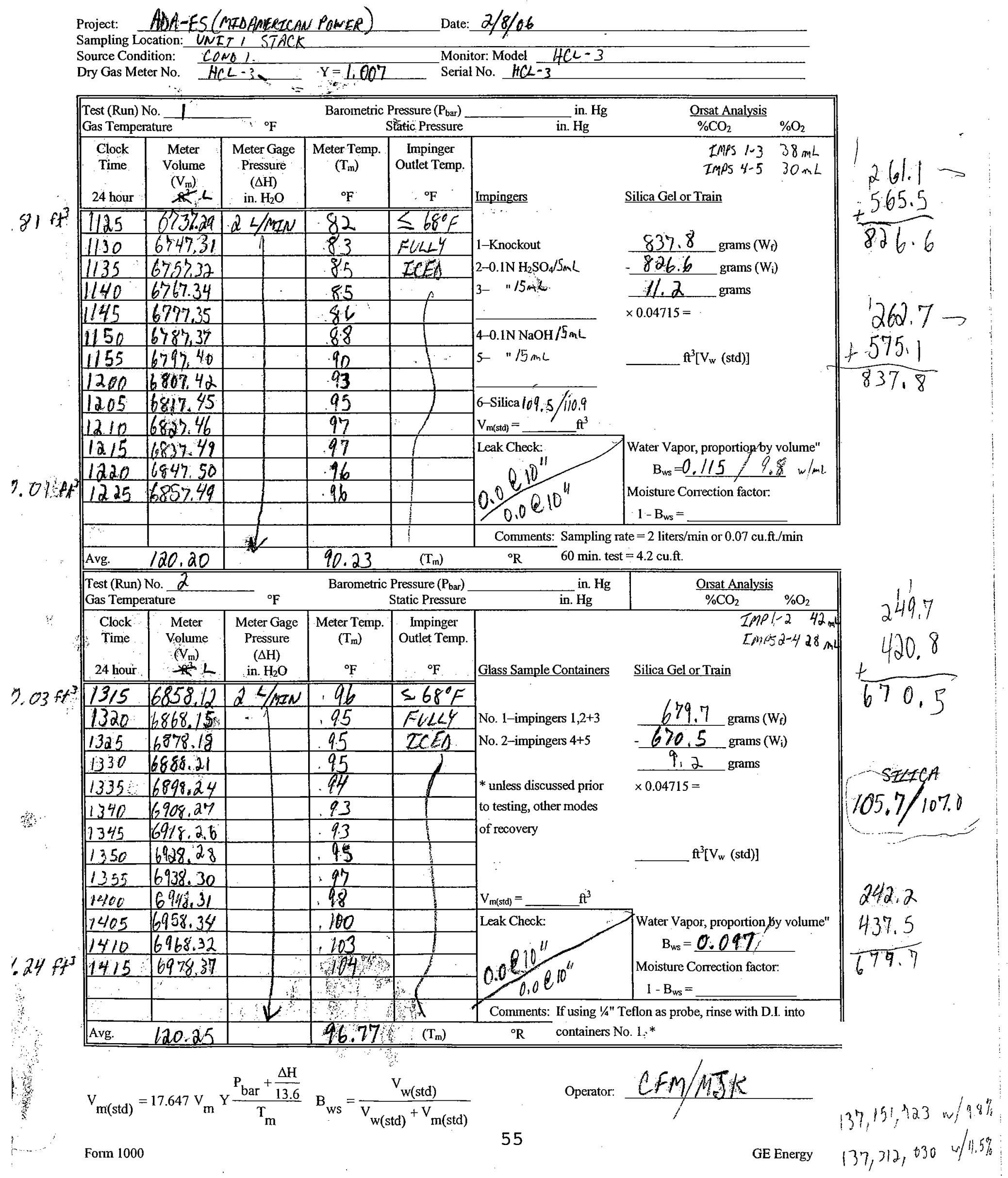


METHOD 26 FIELD DATA SHEET

Project: ADR-ES/MTAAMERTCAN POWER

Sampling Location: VNTT I STACK

Source Condition: $C O M D \mid$

Dry Gas Meter No. $H C L-3$

Date: $2 / 8 / 06$

Monitor. Model $\mathrm{HCl}-3$

Serial No. $H C L-3$

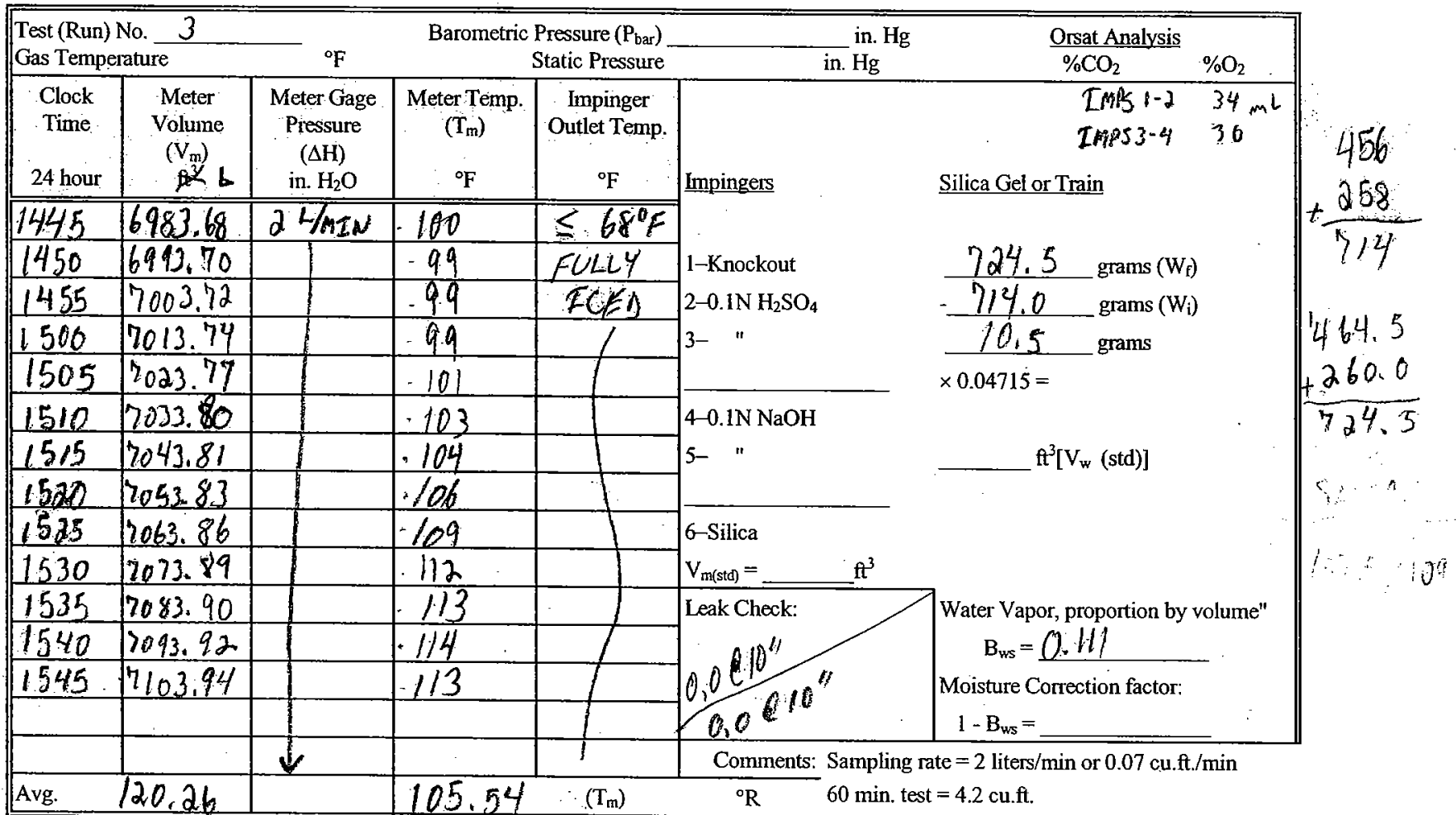

Test (Run) No.

\begin{tabular}{|c|c|c|c|c}
\multicolumn{2}{|c}{ Gas Temperature } & ${ }^{\circ} \mathrm{F}$ & \multicolumn{2}{r}{ Static Pressure } \\
\hline Clock & Meter & Meter Gage & Meter Temp & Impinger
\end{tabular}

Barometric Pressure $\left(\mathrm{P}_{\text {bar }}\right)$

\begin{tabular}{c|c|c|c|c} 
Tune & $\begin{array}{c}\text { Volume } \\
\left(\mathrm{V}_{\mathrm{m}}\right)\end{array}$ & $\begin{array}{c}\text { Pressure } \\
(\Delta \mathrm{H})\end{array}$ & $\begin{array}{c}\text { Meter } \\
\left(\mathrm{T}_{\mathrm{m}}\right)\end{array}$ & Outlet Temp. \\
& & &
\end{tabular}

24 hour $\mathbb{Z}^{2} L$

\begin{tabular}{|l|l|l|l|l|}
\hline 24 hour & ${ }^{2} \mathrm{~L}$ & in. $\mathrm{H}_{2} \mathrm{O}$ & ${ }^{\circ} \mathrm{F}$ & ${ }^{\circ} \mathrm{F}$ \\
\hline & & & & \\
\hline & & & & \\
\hline
\end{tabular}

Glass Sample Containers Silica Gel or Train

No. 1-impingers $1,2+3$

No. 2-impingers $4+5$

grams ( $\left.W_{f}\right)$

\begin{tabular}{|l|l|l|l|l|}
\hline & & & & \\
\hline & & & & \\
\hline
\end{tabular}

* unless discussed prior

to testing, other modes

grams $\left(W_{i}\right)$

grams

\begin{tabular}{|l|l|l|l|l|}
\hline & & & & \\
\hline & & & & \\
\hline & & & & \\
\hline & & & & \\
\hline
\end{tabular}

of recovery

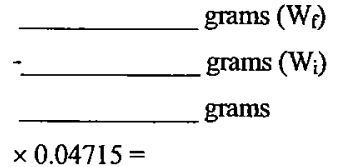

$\mathrm{ft}^{3}\left[\mathrm{~V}_{\mathrm{w}}(\mathrm{std})\right]$

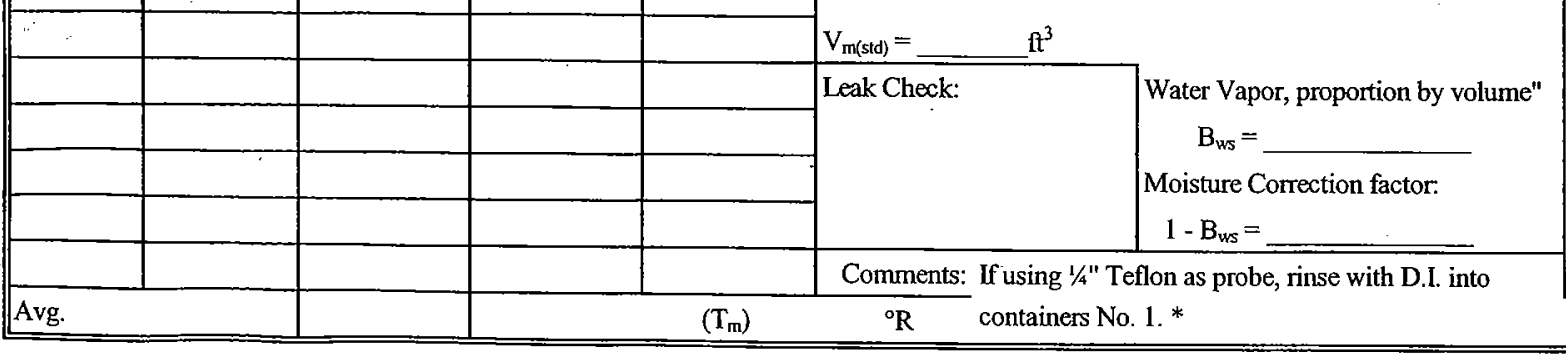

$\mathrm{V}_{\mathrm{m}(\mathrm{std})}=17.647 \mathrm{~V}_{\mathrm{m}} \mathrm{Y} \frac{\mathrm{P}_{\mathrm{bar}}+\frac{\Delta \mathrm{H}}{13.6}}{\mathrm{~T}_{\mathrm{m}}} \mathrm{B}_{\mathrm{ws}}=\frac{\mathrm{V}_{\mathrm{w}(\mathrm{std})}}{\mathrm{V}_{\mathrm{w}(\mathrm{std})}+\mathrm{V}_{\mathrm{m}(\mathrm{std})}}$

operator. $C F M / M J K$

Form 1000 


\section{PITOT TRAVERSE DATA}

Project: ADA-ES(MIDAMERICAN ENERCY)

Location: UNET I STACK

Date: $2 / 9 / 06$ Test No: PRE 1

Time: $\quad 11+16-1205$

\begin{tabular}{|c|c|c|c|c|c|c|c|c|c|}
\hline Point No & $\Delta \mathrm{P}$ & $\sqrt{\Delta P}$ & $t_{s}$ & $\alpha$ & Point No. & $\Delta \mathbf{P}$ & $\sqrt{\Delta P}$ & $t_{s}$ & $\alpha$ \\
\hline $1-1$ & 84 & & 304 & & & & & & \\
\hline 2 & .86 & & 304 & & & & & & \\
\hline 3 & .78 & & 304 & & & & & & \\
\hline 4 & .65 & & 303 & & & & & & \\
\hline & & & & & & & & & \\
\hline $2-1$ & .84 & & 304 & & & & & & \\
\hline 2 & .83 & & 304 & & & & & & \\
\hline 3 & .80 & & 304 & & & & & & \\
\hline 4 & .66 & & 304 & & & & & & \\
\hline & & & & & & & & & \\
\hline $2-1$ & .84 & & 304 & & & & & 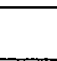 & \\
\hline 7 & .83 & & 305 & & & & & & \\
\hline 3 & .76 & & 304 & & & & & & \\
\hline 4 & .63 & & 303 & & & & & & \\
\hline & & & & & & & & & \\
\hline $3-1$ & .86 & & 304 & & & & & & \\
\hline 2 & .87 & & 305 & & & & & & \\
\hline 3 & .83 & & 3.05 & & & & & & \\
\hline 4 & .69 & & 305 & & & & & & \\
\hline & & & 3 & & & & & & \\
\hline & & & & & & & & & \\
\hline & & & & & & & & & \\
\hline & & & & & & & & & \\
\hline & & & & & & & & & \\
\hline
\end{tabular}

Preliminary Velocity Calculation (This data has not been'peer reviewed and may not be accurate)

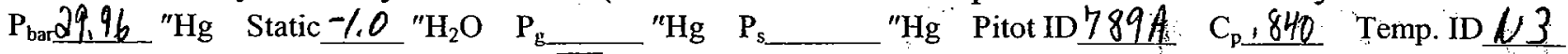

$0.44 \times 13.9 \% \mathrm{CO}_{2}=$

${ }^{\circ} \mathrm{F} \quad \mathrm{T}$

$0.32 \times 5.6 \% \mathrm{O}_{2}=+$

$0.28 \times$ $\% \mathrm{~N}_{2}=+$

$\sqrt{\Delta \mathrm{P}}$ $\therefore \mathrm{t}_{\mathrm{s}} \quad{ }^{\circ} \mathrm{F}$

$1-B_{w s}$

Bws) $=$
Flue Area

Duct Dimensions $32,15,^{\prime} / t^{\circ}$

Disturbance: Upstream

Downstream

$$
\mathrm{v}_{\mathrm{s}}=85.49 \times \ldots \mathrm{Cp} \times \sqrt{\frac{(\ldots+\ldots)}{\mathrm{Ms} \times \ldots \mathrm{C}^{\circ} \mathrm{R}}} \times \ldots \sqrt{\Delta \mathrm{P}}=\ldots \mathrm{ft} / \mathrm{sec}(\mathrm{Vs})
$$

$\mathrm{Q}_{\text {acfin }}=\ldots$ Vs $\times \ldots$ Flue Area $\times 60=$

$\mathrm{Q}_{\text {scfin }}=17.647 \times \mathrm{ACFM} \times \frac{\mathrm{Ps}}{\mathrm{Ts}^{\circ} \mathrm{R}}=$

acfm

Port Length $18 \quad$ Inches

$\mathrm{Q}_{\mathrm{dscfin}}=17.647 \times \mathrm{ACFM} \times \frac{\mathrm{Ps}}{\mathrm{Ts}^{\circ} \mathrm{R}} \times(1-\mathrm{Bws})=$

DSCFM

Pre-test leak check 0.0 " $\mathrm{H}_{2} \mathrm{O}_{3} \mathrm{O}_{3} /$

Post-test leak check $0.0 " \mathrm{H}_{2} \mathrm{OQ} 3 "$

Data Taken By: CFM/MJK 


\section{PITOT TRAVERSE DATA}

Project: ADA-ES (MIDAMGETCAN ENERGY)

Location: UNAT I STACK

Date: $2 / 9 / 06$ Test No: POST 1/PREL Time: 1238-1355

\begin{tabular}{|c|c|c|c|c|c|c|c|c|c|}
\hline Point No. & $\Delta \mathrm{P}$ & $\sqrt{\Delta P}$ & $t_{s}$ & $\alpha$ & Point No. & $\Delta P$ & $\sqrt{\Delta \mathbf{P}}$ & $t_{s}$ & $\alpha$ \\
\hline $1-1$ & 89 & & 306 & & & & & & \\
\hline 2 & .79 & & 306 & & & & & & \\
\hline 3 & .74 & & 305 & & & & & & \\
\hline 4 & .57 & & 304 & & & & & & \\
\hline & & & & & & & & & \\
\hline $2-1$ & .75 & & 304 & & & & & & \\
\hline 2 & .73 & & 303 & & & & & & \\
\hline 3 & .70 & & 303 & & & & & & \\
\hline 4 & .59 & & 303 & & & & & & \\
\hline & & & & & & & & & \\
\hline$n-1$ & .78 & & 303 & & & & & & \\
\hline 2 & .75 & & 304 & & & & & & \\
\hline 3 & .72 & & 303 & & & & & & \\
\hline 4 & .60 & & 303 & & & & & & \\
\hline & & & & & & & & & \\
\hline $3-1$ & .75 & & 303 & & & & & & \\
\hline 2 & .75 & & 303 & & & & & & \\
\hline 3 & .69 & & 302 & & & & & & \\
\hline 4 & .61 & & 302 & & & & & & \\
\hline & & & & & & & & & \\
\hline & & & & & & & & & \\
\hline & & & & & & & & & \\
\hline & & & & & & & & & \\
\hline & & & & & & & & & \\
\hline
\end{tabular}

Preliminary Velocity Calculation (This data has not been peer reviewed and may not be accurate)

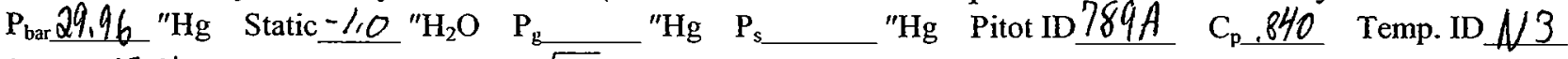
$0.44 \times 13.4 \% \mathrm{CO}_{2}=\square \sqrt{\Delta \mathrm{P}} \quad \mathrm{t}_{\mathrm{s}}{ }^{\circ} \mathrm{F} \quad \mathrm{T}$ $0.32 \times 6.2 \% \mathrm{O}_{2}=+$
$0.28 \times \ldots \mathrm{N}_{2}=+$ $\mathrm{B}_{\mathrm{ws}}$ $1-B_{w s}$ $\mathrm{Md} \times$ $1-\mathrm{Bws})+(18 \times$ Bws) $=$ (Ms)

Flue Area $\mathrm{ft}^{2}$

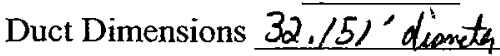

$$
\text { L }
$$

$$
\mathrm{v}_{\mathrm{s}}=85.49 \times
$$

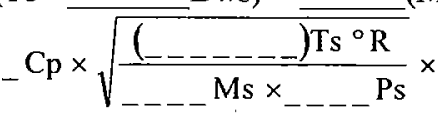

$\mathrm{Q}_{\text {acfin }}=\ldots$ Vs $\times \quad$ Flue Area $\times 60=$ acfm SCFM

$\mathrm{Q}_{\text {scfin }}=17.647 \times \mathrm{ACFM} \times \frac{\mathrm{Ps}}{\mathrm{Ts}^{\circ} \mathrm{R}}=$

$\mathrm{Q}_{\mathrm{dscfin}}=17.647 \times \mathrm{ACFM} \times \frac{\mathrm{Ps}}{\mathrm{Ts}^{\circ} \mathrm{R}} \times(1-\mathrm{Bws})=$

DSCFM

Pre-test leak check $\underline{\mathrm{O} O} \mathrm{O}^{\prime \prime} \mathrm{H}_{2} \mathrm{OQ} z^{\prime \prime}$

Post-test leak checkOrO " $\mathrm{H}_{2} \mathrm{OQB}_{3} 3^{\text {" }}$

Data Taken By: CFM/MJK 


\section{PITOT TRAVERSE DATA}

Project: ADA-ES (MIDMMERICAN ENERGY)

Location: UNIT I STACK

Date: $2 / 9 / 06$

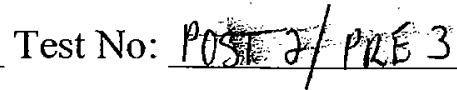

Time: $\quad 1520-1535$

\begin{tabular}{|c|c|c|c|c|c|c|c|c|c|}
\hline Point No & $\Delta \mathrm{P}$ & $\sqrt{\Delta \mathrm{P}}$ & $\mathrm{s}$ & $a$ & Point No & $\triangle P$ & $\sqrt{\triangle P}$ & $t_{s}$ & $\alpha$ \\
\hline $1-1$ & .84 & & 2999 & & & & & & \\
\hline 2 & .80 & & 299 & & & & & & \\
\hline 3 & .77 & & 299 & & & & & & \\
\hline 4 & .61 & & 298 & & & & & & \\
\hline & & & & & & & & & \\
\hline $2-1$ & .81 & & 80 & & & & .0 & & \\
\hline 2 & .80 & & 300 & & & & 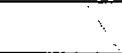 & & \\
\hline 3 & .78 & & 300 & & & & & & \\
\hline 4 & .66 & & 299 & & & & & 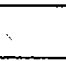 & \\
\hline & & & & & & & & & \\
\hline $2-1$ & .80 & & 301 & & & & & & \\
\hline 2 & 81 & & 300 & & & & & & \\
\hline 3 & .77 & . & 301 & & & & & & \\
\hline 4 & .65 & & 299 & & & & & & \\
\hline & & & & & & & & & \\
\hline $3-1$ & .84 & & 301 & & & & & & \\
\hline 2 & 79 & & 301 & & & & & & \\
\hline 3 & .76 & & 300 & & & & & & \\
\hline 4 & .65 & & 299 & & & & & & \\
\hline & & & & & & & & & \\
\hline & & & $\therefore$ & & & & & & \\
\hline & & & & & & & & & \\
\hline & & & & & & & & & \\
\hline & & & & & & & & & \\
\hline
\end{tabular}

Preliminary Velocity Calculation (This data has not been peer reviewed and may not be accurate)

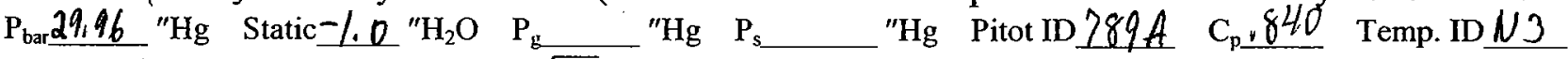
$0.44 \times \frac{14}{5,1} \% \mathrm{CO}_{2}=$ $0.32 \times 5.7 \% \mathrm{O}_{2}=+$
$0.28 \times$ $\% \mathrm{~N}_{2}=+$ $\sqrt{\Delta \mathrm{P}}$ ${ }^{\circ} \mathrm{F} \quad \mathrm{T}$ ( Md $\times$

$$
\begin{aligned}
& +B_{w s} \quad 1-B_{w s}
\end{aligned}
$$

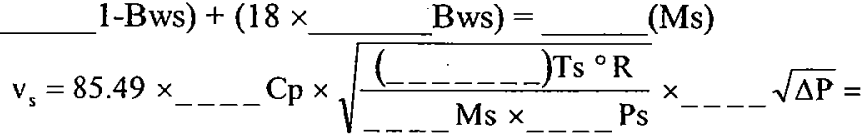

Disturbance: Upstream

Downstream

$\mathrm{Q}_{\mathrm{acin}}=\ldots$ Vs $\times \ldots$ Flue Area $\times 60=$

$\mathrm{Q}_{\mathrm{scfin}}=17.647 \times \mathrm{ACFM} \times \frac{\mathrm{Ps}}{\mathrm{Ts}^{\circ} \mathrm{R}}=$ acfm $\mathrm{ft} / \sec (\mathrm{Vs})$

$\mathrm{Q}_{\mathrm{dscfin}}=17.647 \times \mathrm{ACFM} \times \frac{\mathrm{Ps}}{\mathrm{Ts}^{\circ} \mathrm{R}} \times(1-\mathrm{Bws})=$ DSCFM

Pre-test leak check 0.0 " $\mathrm{H}_{2} \mathrm{O}, 3$ "

Post-test leak check $0 . \mathrm{O}^{\prime \prime} \mathrm{H}_{2} \mathrm{O}$ (6) 


\section{PITOT TRAVERSE DATA}

Project: ADA- ES (MTGDAMERTCAN ENERGY)

Location: UUAT I STACK

Date: $2 / 9 / 06 \quad$ Test No: POST 3 Time: 1632-1651

\begin{tabular}{|c|c|c|c|c|c|c|c|c|c|}
\hline Poin No & $\Delta \mathrm{P}$ & $\sqrt{A P}$ & $\mathrm{xt}_{\mathrm{s}}$ & a & Pont No & $\Delta \mathrm{P}$ & $\sqrt{\Delta \mathrm{P}}$ & (5) & 20 \\
\hline $1-1$ & .83 & & 303 & & & & & & \\
\hline 2 & .82 & & 303 & & & & $\therefore$ & & \\
\hline 3 & 182 & & 303 & & & & & & \\
\hline 4 & 67 & & 302 & & & & & & \\
\hline & & & & & & & & & \\
\hline $2-1$ & .86 & & 303 & & & & & & \\
\hline 2 & .85 & & 304 & & & & & & \\
\hline 3 & .80 & & 304 & & & & & & \\
\hline 4 & .69 & & 303 & & & & & & \\
\hline & & & & & & & & & \\
\hline $2-1$ & .84 & & 305 & & & & & & \\
\hline 2 & .82 & & 304 & & & & & & \\
\hline 3 & .79 & & 304 & & & & & & \\
\hline 4 & .64 & & 303 & & & & & & \\
\hline & & & & & & & & & \\
\hline $3-1$ & .82 & & 303 & & & & & & \\
\hline 2 & .80 & & 303 & & & & & & \\
\hline 13 & 82 & & 307 & & & & & & \\
\hline 14 & 18 & & 301 & & & & & & \\
\hline 8 & & & & & & & & & \\
\hline & & & & & & & & & \\
\hline & & & & & & & & & \\
\hline & & & & & & & & & \\
\hline & & & & & & & & & \\
\hline
\end{tabular}

Preliminary Velocity Calculation (This data has not been peer reviewed and may not be accurate)

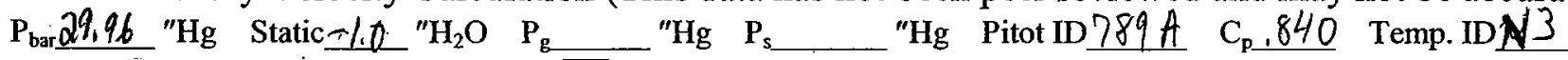
$0.44 \times 12.0 \% \mathrm{CO}_{2}=$ $0.32 \times 5.6 \% \mathrm{O}_{2}=+$ $0.28 \times \% \mathrm{~N}_{2}=+$ $\sqrt{\Delta \mathrm{P}} \quad \mathrm{t}_{\mathrm{s}} \quad{ }^{\circ} \mathrm{F} \quad \mathrm{T}{ }^{\circ} \mathrm{R}$ Md $\times$

$+B_{w s} \quad 1-B_{w s}$

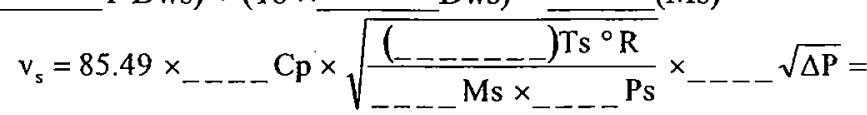

Flue Area $\mathrm{ft}^{2}$

Duct Dimensions 32.151' diameter Disturbance: Upstream Downstream

$\mathrm{Q}_{\text {acfin }}=\ldots \mathrm{Vs} \times \ldots$ Flue Area $\times 60=$ acfm SCFM

$\mathrm{Q}_{\mathrm{scfin}}=17.647 \times \mathrm{ACFM} \times \frac{\mathrm{Ps}}{\mathrm{Ts}^{\circ} \mathrm{R}}=$

$\mathrm{Q}_{\mathrm{dscfin}}=17.647 \times \mathrm{ACFM} \times \frac{\mathrm{Ps}}{\mathrm{Ts}^{\circ} \mathrm{R}} \times(1-\mathrm{Bws})=$ DSCFM

Pre-test leak check $0.0 " \mathrm{H}_{2} \mathrm{O} \odot 3 \%$

Post-test leak check $\underline{0.0}$ " $\mathrm{H}_{2} \mathrm{O} \bigcirc 3^{\prime \prime}$
Data Taken By: 


\section{METHOD 26 FIELD هATA SHEET}

Project: $\frac{\text { ADA-ESS(MADAMERTCAN ENERGY) }}{\text { Sampling Location: }}$ Date: $2 / 9 / 06$

Source Condition: COND 2

Dry Gas Meter No. HCL -3 Monitor: Model \# $\mathrm{HCL}-3$ Serial No. HACL-3

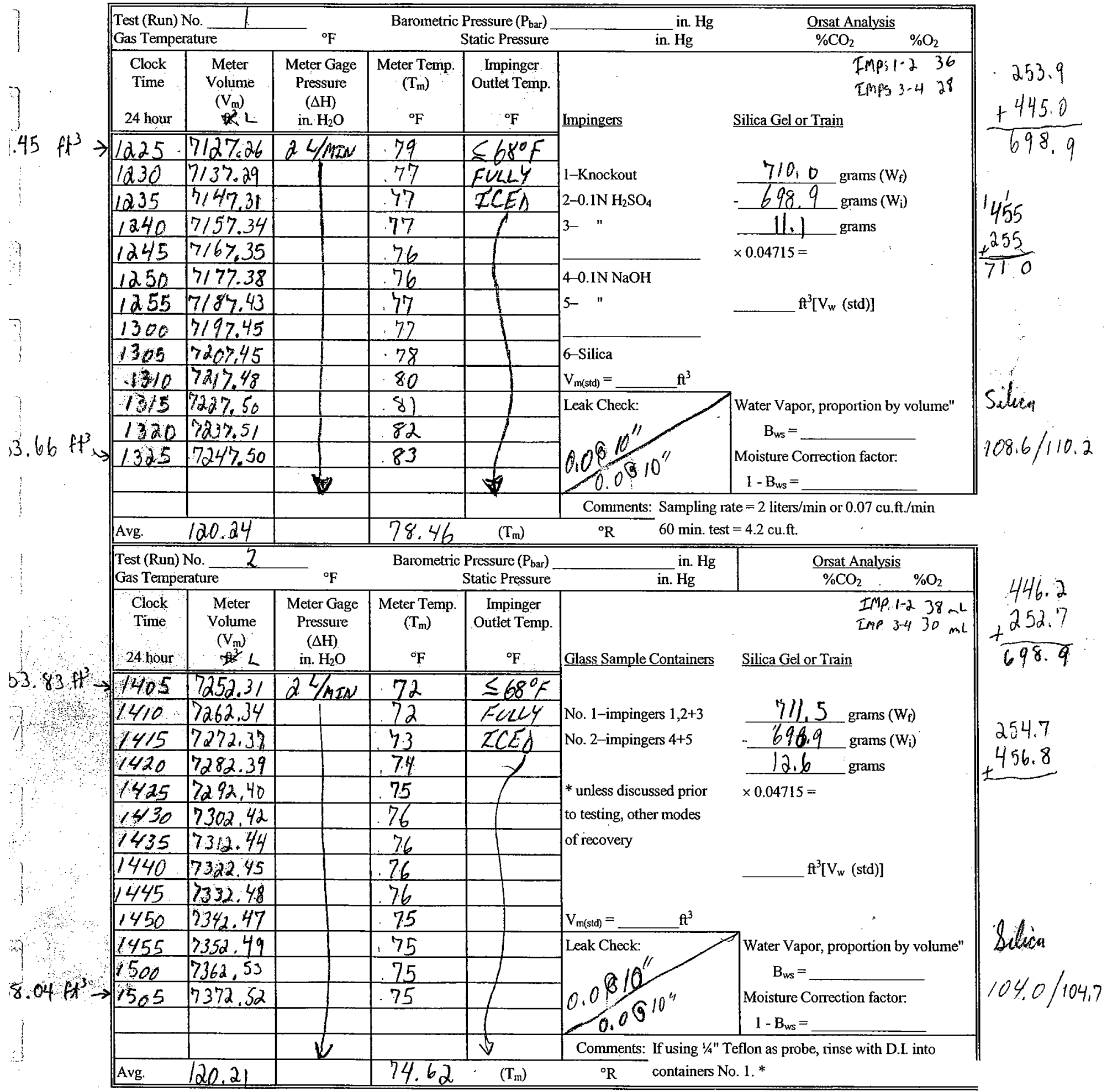

$\mathrm{V}_{\mathrm{m}(\mathrm{std})}=17.647 \mathrm{~V}_{\mathrm{m}} \mathrm{Y} \frac{\mathrm{P}_{\mathrm{bar}}+\frac{\Delta \mathrm{H}}{13.6}}{\mathrm{~T}_{\mathrm{m}}} \quad \mathrm{B}_{\mathrm{ws}}=\frac{\mathrm{V}_{\mathrm{w}(\mathrm{std})}}{\mathrm{V}_{\mathrm{w}(\mathrm{std})}+\mathrm{V}_{\mathrm{m}(\mathrm{std})}}$

Form 1000
Operator:

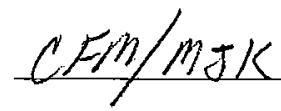


METHOD 26 FIELD DATA SHEET

Project: ADA-ES/MIDAMERZCAN ENERGY Date: $2 / 9 / 06$

Source Condition: CONB

Dry Gas Meter No. $\quad$ It $/ \mathrm{HCL}-3 \quad \mathrm{Y}=1607 \quad$ Monitor: Model H HCL-3

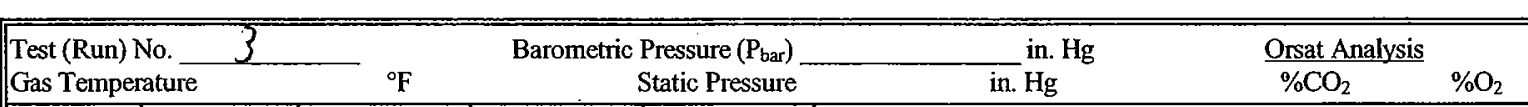

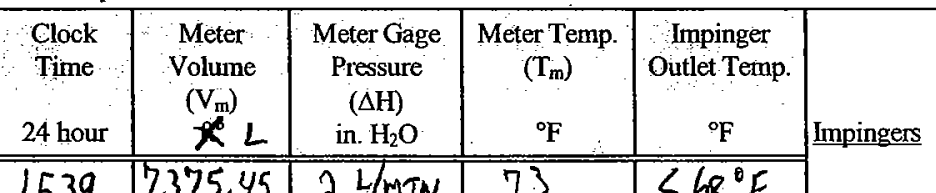

\begin{tabular}{|c|c|c|c|c|}
\hline 1539 & 7375.45 & $2 L / M I N$ & 73 & $\angle 68^{\circ} \mathrm{F}$ \\
\hline 1544 & 7385.46 & 1 & 74 & FUALY \\
\hline 1549 & 7395.49 & & 75 & ICE \\
\hline
\end{tabular}

15547405,5

15597415.53

16047425.32

\begin{tabular}{l|l}
1609 & 7435.54 \\
\hline
\end{tabular}

$1614 \quad 7445.56$

\begin{tabular}{l|l}
1619 & 7455.54 \\
\hline
\end{tabular}

1624.7465 .59

16297475.62

\begin{tabular}{|l|l|l|l|l|}
\hline 1634 & 3485.61 & & & 90 \\
\hline 1639 & 7495.64 & & & 93 \\
\hline & & & \\
\hline & & & \\
\hline Avg. & & & \\
\hline
\end{tabular}

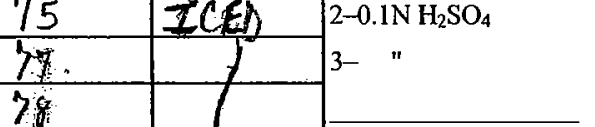

\begin{tabular}{|l|l}
\hline Test (Run) No. & \\
Gas Temperature & of
\end{tabular}

$4-0.1 \mathrm{~N} \mathrm{NaOH}$

$5-"$

$\underline{\text { Silica Gel or Train }}$

\section{6-Silica}

82

\begin{tabular}{|c|c|c|c|c|}
\hline $\begin{array}{l}\text { Clock } \\
\text { Time } \\
24 \text { hour }\end{array}$ & $\begin{array}{c}\text { Meter } \\
\text { Voluime } \\
\left(\mathrm{V}_{\mathrm{m}}\right) \\
\mathrm{ft}^{3}\end{array}$ & $\begin{array}{c}\text { Meter Gage } \\
\text { Pressure } \\
(\Delta \mathrm{H}) \\
\text { in } \mathrm{H}_{2} \mathrm{O}\end{array}$ & $\begin{array}{c}\text { Meter Temp. } \\
\left(\mathrm{T}_{\mathrm{m}}\right) \\
{ }^{\circ} \mathrm{F}\end{array}$ & $\begin{array}{l}\text { Impinger } \\
\text { Outlet Temp. } \\
\qquad \mathrm{F}\end{array}$ \\
\hline
\end{tabular}

\begin{tabular}{|l|l|l|l|l|}
\hline & & & & \\
\hline & & & & \\
\hline
\end{tabular}

Glass Sample Containers Silica Gel or Train

No. 1-impingers $1,2+3$

No. 2-impingers $4+5$

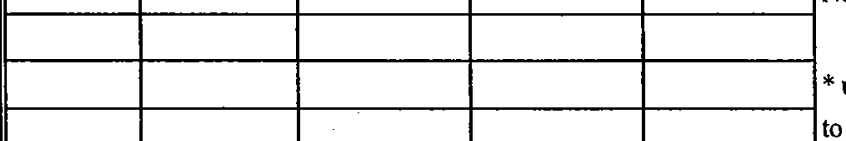

* unless discussed prior

to testing, other modes

Water Vapot proportion by:volume"

Sulver

of recovery

$$
\mathrm{ft}^{3}\left[\mathrm{~V}_{\mathrm{w}}(\mathrm{std})\right]
$$

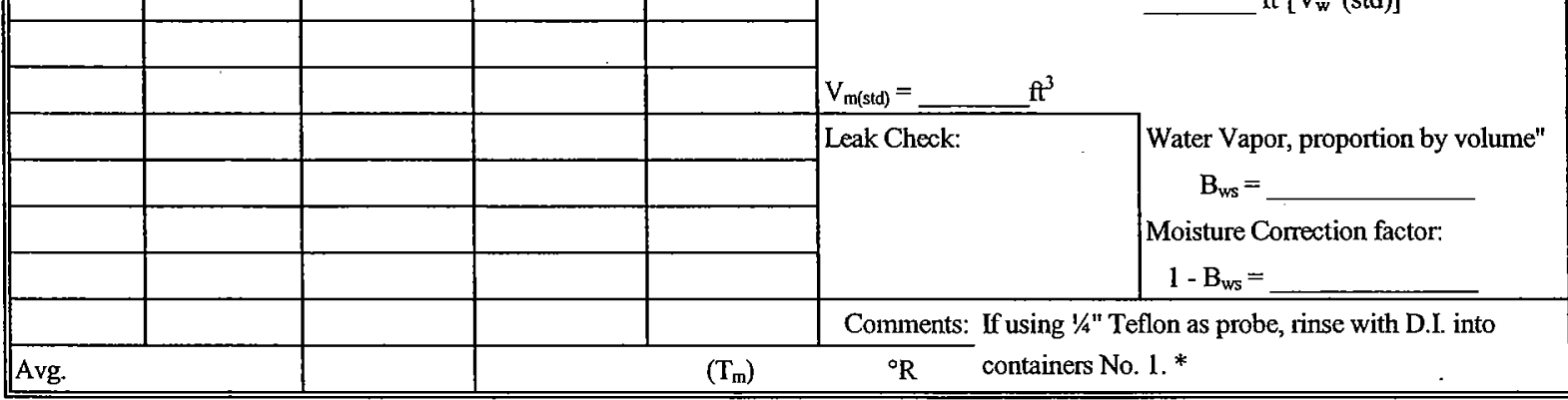

$\mathrm{V}_{\mathrm{m}(\mathrm{std})}=17.647 \mathrm{~V}_{\mathrm{m}} \mathrm{Y} \frac{\mathrm{P}_{\mathrm{bar}}+\frac{\Delta \mathrm{H}}{13.6}}{\mathrm{~T}_{\mathrm{m}}} \quad \mathrm{B}_{\mathrm{ws}}=\frac{\mathrm{V}_{\mathrm{w}(\mathrm{std})}}{\mathrm{V}_{\mathrm{w}(\mathrm{std})}+\mathrm{V}_{\mathrm{m}(\mathrm{std})}}$ 